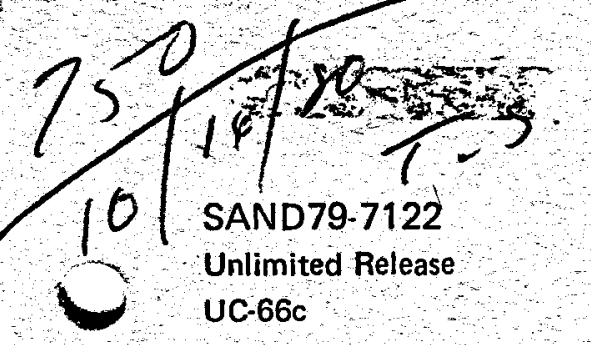

\title{
Development of Drilling Foams for Geothermal Applications
}

\section{MASTER}

William J. McDonald, Larry J. Remont, William A. Rehm

Maurer Engineering, Inc.

Martin E. Chenevert, Chenevert and Associates

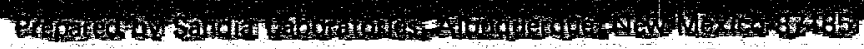

and Livermore, California 94550 for the United States Department

of Energy under Contract DE-ACO4-76DPO0789

Printed January 1980

\section{6i Sandia National Laboratories}




\section{DISCLAIMER}

This report was prepared as an account of work sponsored by an agency of the United States Government. Neither the United States Government nor any agency Thereof, nor any of their employees, makes any warranty, express or implied, or assumes any legal liability or responsibility for the accuracy, completeness, or usefulness of any information, apparatus, product, or process disclosed, or represents that its use would not infringe privately owned rights. Reference herein to any specific commercial product, process, or service by trade name, trademark, manufacturer, or otherwise does not necessarily constitute or imply its endorsement, recommendation, or favoring by the United States Government or any agency thereof. The views and opinions of authors expressed herein do not necessarily state or reflect those of the United States Government or any agency thereof. 


\section{DISCLAIMER}

Portions of this document may be illegible in electronic image products. Images are produced from the best available original document. 
Issued by Sandia National Laboratories, operated for the United States Department of Energy by Sandia Corporation.

\section{NOTICE}

This report was prepared as an account of work sponsored by the United States Governmemt. Neither the United States nor the Department of Energy, nor any of their employees, nor any of their contractors, subcontractors, or their employees, makes any warranty, express or implied, or assumes any legal liability or responsibility for the accuracy, completeness or usefuiness of any information, apparatus, product or process disclosed, or represents that its use would not infringe privately owned rights. 
SAND79-7122

Unlimited Release

Category UC-66C

Printed January 1980

DEVELOPMENT OF DRILLING FOAMS FOR GEOTHERMAL APPLICATIONS*

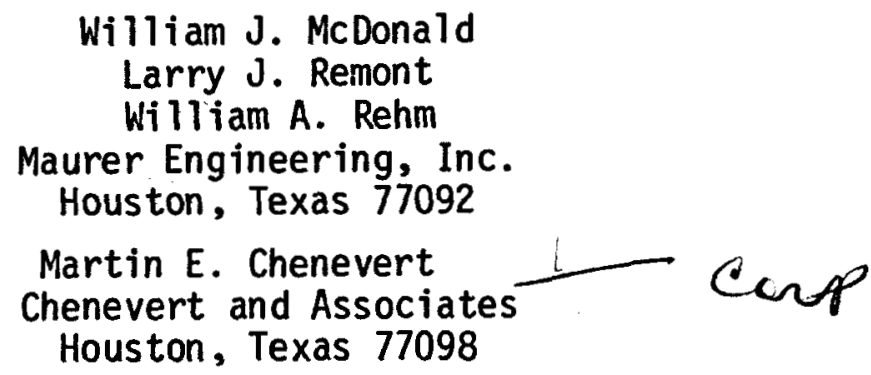

Printed in the United States of America

National Technical Information Service

U. S. Department of Commerce

5285 Port Royal Road

Springfield, VA 22161

Price: Printed Copy $\$ 7.50$; Hicrofiche $\$ 3.00$

ॠWork performed under Sandia Contract No. 07-7068; sponsored by the U.S. Department of Energy, Division of Geothermal Energy.

DISTRHEUTION OF THIS DOCUMENT IS UNLIMITE 
$\longrightarrow$ 


\section{ACKNOWLEDGMENT}

The authors gratefully acknowledge the efforts and participation of many individuals in this study. The time and interest of industry personnel in contributing of their ideas and experience is particularly appreciated. While these people are too numerous to list the help of William Glass (Big Chief Drilling), Stan Hutchinson (Chevron), jim Kingsolver (Smith), Harvey Mallory (Loffland), and Del Pyle (Union) is especially acknowledged. We also appreciate the assistance of John Thuren of the University of oklahoma in interviewing many of the industry personnel and in conducting the resource interviews with academic authorities.

Manufacturers and marketers of foam materials generously supplied samples and technical counsel on their materials. Their help enabled the testing portion of this study to be successful and productive.

The authors appreciate the support and assistance of Sam Varnado, manager of the Sandia Geothermal Well Technology Program, and Jon Barnette, project leader of the drilling technology efforts in this program.

Finally, the interest and efforts of Cliff Carwile of the Department of Energy, Division of Geothermal Energy, is gratefully acknowledged. For under such leadership it is believed that technology for bet er and cheaper geothermal drilling will be developed. 
( 


\section{ABSTRACT}

This report, prepared at the request and under contract to Sandia Laboratories, addresses the use of foam drilling fluids in geothermal applications. The initial three chapters provide a description of foams--what they are, how they are used, their properties, equipment required to use them, the advantages and disadvantages of foams, etc.

Geothermal applications are discussed. Results of industry interviews presented indicate significant potential for foams, but also indicate significant technical problems to be solved to achieve this potential. Testing procedures and results of tests on represenative foams provide a basis for work to develop high-temperature foams. A seven year directed effort to develop the needed materials and equipment is presented. 
$\mathcal{U}$

U 
II REVIEW OF FOAM DRILLING 25

III MECHANICAL AND CHEMICAL PROPERTIES OF FOAMS 43

IV APPLICATION OF FOAMS IN GEOTHERMAL DRILLING 53

A. Survey 54

B. Technical Problems 56

C. Borehole Environmental Zones That Favor Foams As A Drilling Fluid

$\checkmark$ FOAM TEST PROCEDURES 67

$V I$ SELECTION AND TESTING OF FOAMS 89

$\begin{array}{ll}V I I & 100\end{array}$

Appendicies
A. Analysis of Foam Column Density 109
B. Bibliography 117
C. Abstracts 123
D. Computer Bibliography 133
E. Questionnaires 167 
C

$\mathcal{U}$ 
Problems resulting from inadequate drilling fluids are the most frequently quoted reason for high geothermal drilling costs. Severe corrosion and erosion are common when air drilling: yet slow drilling rates, filtration control or loss of circulation, and mud gelation often occur when using muds. In order to ascertain how drilling foams might be utilized in geothermal drilling to solve some of these problems (hence reducing geothermal well costs) Sandia Laboratories contacted with Maurer Engineering to evaluate drilling foams for geothermal applications and to recommend a program for developing geothermal drilling foams.

Drilling foams are potentially applicable in air drilling situations namely where well control is not a problem. Foams offer advantages over air in their increased lifting capacity, reduced compression requirements, higher bottom hole densities, and improved borehole stabilization. A broad survey of industry personnel indicates that geothermal drilling could use foams up to $80 \%$ of the time. Use of foams could increase drilling rate, decrease downtime, decrease corrosion/erosion effects, help control lost circulation, and help alleviate other geothermal drilling problems. Yet many technical problems must be overcome to accomplish these things.

Temperature and salt stable foams must be developed. Handling equipment must be improved including developing processes for breaking, cleaning, and reusing foam materials. 
Corrosion characteristics must be improved through the use of inert gases or chemical additives, and other technical problems must be addressed. Results of this study also indiates that wide use of foams will require informing operators and contractors about foams and their use and will require much greater availablility of equipment than present.

Numerous laboratory procedures were considered for testing foams; all have some usefullness, yet all have limitations. Probably the single most descriptive test is a modified Chevron test after high-temperature static aging. Although present procedures are useful screening tools better test equipment and procedures (such as a hightemperature flow simulator for foams) should be developed. Test of representative foams give insight into anticipated behavior of families of materials and the performance which can be expected from field drilling foams. These tests indicate that completely new materials will have to be developed in order to satisfy geothermal applications.

A proposed program for developing geothermal drilling foams recommends a 7-year development period with expenditures anticipated at $\$ 1.9 \mathrm{million}$. Technical goals should be achievable in 5 -years with remaining 2 -years to complete testing, demonstration, and technology transfer. It is anticipated that significant industry cost sharing will augment the $\$ 1.9 \mathrm{mill}$ ion of DOE funds. 


\section{CONCLUSIONS AND RECOMMENDATIONS}

The following is an enumeration of conclusions regarding geothermal drilling foams. These conclusions are based on 1) extensive discussions with geothermal drilling and operating personnel, 2) literature review, 3) testing of candidate materials, 4) recommendations of manufacturers and suppliers, and 5) consultation with academic authorities.

The major conclusions are:

- There are severe technical problems with geothermal drilling foams relating stability, contamination, handling and costs.

- Improved foams can have major impact on geothermal well costs, saving from $\$ 30,000$ to $\$ 300,000$ per well.

- A major federal initiative is needed to develop the required technology. This role is strongly urged and supported by industry.

Detailed conclusions drawn and supported by this study are be low:

\section{Applicability of Geothermal Foams}

1. Foams would be used in up to $80 \%$ of geothermal drilling if technical problems with foams can be solved.

2. Foams potentially could solve or alleviate the following important problems.

A. Corrosion/Erosion

B. Mud Gelation

C. Filtration Control/formation Damage

D. Lost Circulation

E. High Mud Maintenance Costs

3. Foams will be excellent for cementing and workover procedures.

4. Conservatively estimated, foams can reduce overall geothermal well cost from 3 to $30 \%$. 
4. Reduced fishing, presently averaging (with air drilling) 4 jobs/rig/year at $\$ 250,000 /$ job. Estimated savings $\$ 100,000-\$ 200,00$ per well.

5. Improved drilling rate $\$ 20,000-\$ 30,000$ per well saving in rig time.

Total economic benefits range from $\$ 30,000$ to $\$ 300,000$ per well, or approximately $3 \%$ to $30 \%$ of total well costs.

\section{Testing}

1. Numerous lab tests are available. Most definitive in common use is a test developed by Chevron and modified slightly to include Chevron static hightemperature aging.

2. Improved lab procedures are needed. In particular a flow loop for testing foams should be developed.

3. A catalog of foams giving composition and lab performance should be developed.

4. A field test facility is needed.

5. High-temperature performance of foams is not predictable from low-temperature performance.

\section{Development Program}

1. A majority of interviewees strongly supported federal RED effort to develop foam fluids for geothermal drilling.

2. Benefits from even a partial solution to the problems are great and a program should be initiated immediately.

3. Total program cost is estimated to be $\$ 1.9$ million. Development time totals 7-years with all major goals expected to be achieved in 5-years.

4. Technology transfer should be a major effort to assure implementation of accomplishments. 
Technical Problems

1. Present foams are not stable under a range of temperature, pressure, and salinity of conditions.

A. pH can suddenly change with thermal degradation

B. Foam quality (air/water ratio) can be seriously impaired by hydrocarbon impurities and brine influx.

2. Foams built with air are corrosive. An economic method of building foams with inert gas must be found. Stable, economic chemical corrosion inhibitors may solve near-term problems.

3. Systems to break, clean, and reuse foam materials must be developed for foams to be economic and to avoid disposal problems.

4. Borehole stability is a major problem. Methods of prediction and control must be developed.

5. Bit life with foams is low and bit cleaning is not as good as with air or mud.

6. Present material costs are high and yields are often much lower than lab predictions.

7. Foam quality, density, and carrying capacity vary with depth; predictive methods are not good.

8. Impact of low thermal conductivity and low heat capacity of foams (allowing higher borehole temperature during drillingl is unknown.

\section{Economic Benefits}

1. Reduced equipment costs over air drilling; possible savings of $\$ 1,500-\$ 2,000 /$ day $(\$ 50,000-\$ 100,000$ per well).

2. Reduced drill pipe corrosion/erosion allowing estimatad 40-fold improvements in drill pipe life. Estimated savings of $\$ 30,000-\$ 40,000$ per well.

3. Reduced hard banding costs and pipe inspection costs saving $\$ 2,000-\$ 4,000$ per well. 
Drilling with air instead of mud as a circulating fluid was first used in the oil fields in the 1930's. In some shallow drilling in hard dry rock, air drilling worked well and drilled faster than mud. In other areas, air drilling was severely limited because of large influxes of formation fluids into the wellbore and because of hole sloughing problems.

The obvious approach to this was to combine air and drilling mud into aerated mud. This was done as early as the late 1940's but usually the results were disappointing. The foam was generally too expensive, and the system too unstable. Nevertheless, since that time there has been considerable work done with aerated muds, and given close supervision under the proper hole conditions they have performed well in many areas.

\section{AEC Stiff Foams}

A major development in the use of foams was made in 1965 by the A.E.C. on their test sites at Frenchman's Flat and Piute Mesa, Nevada. In this area the rhyolite rock of the test sites had been pulverized by the shock of the explosions or was extensively fractured. Drilling muds caused lost returns, yet there was too much water in the rock for air drilling. Also, the pulverized rock caved into the hole when drilling with air.

Faced with this problem, the test site engineers developed the "stiff foam" drilling fluid. The material was a drilling mud which contained a large quantity of entrained air. The resulting mixture looked like aerosol shaving foam, 
but was very stable and persistent as shown in Figure 1.1. It had good lifting capacity, was lighter than water and helped support the walls of the hole.

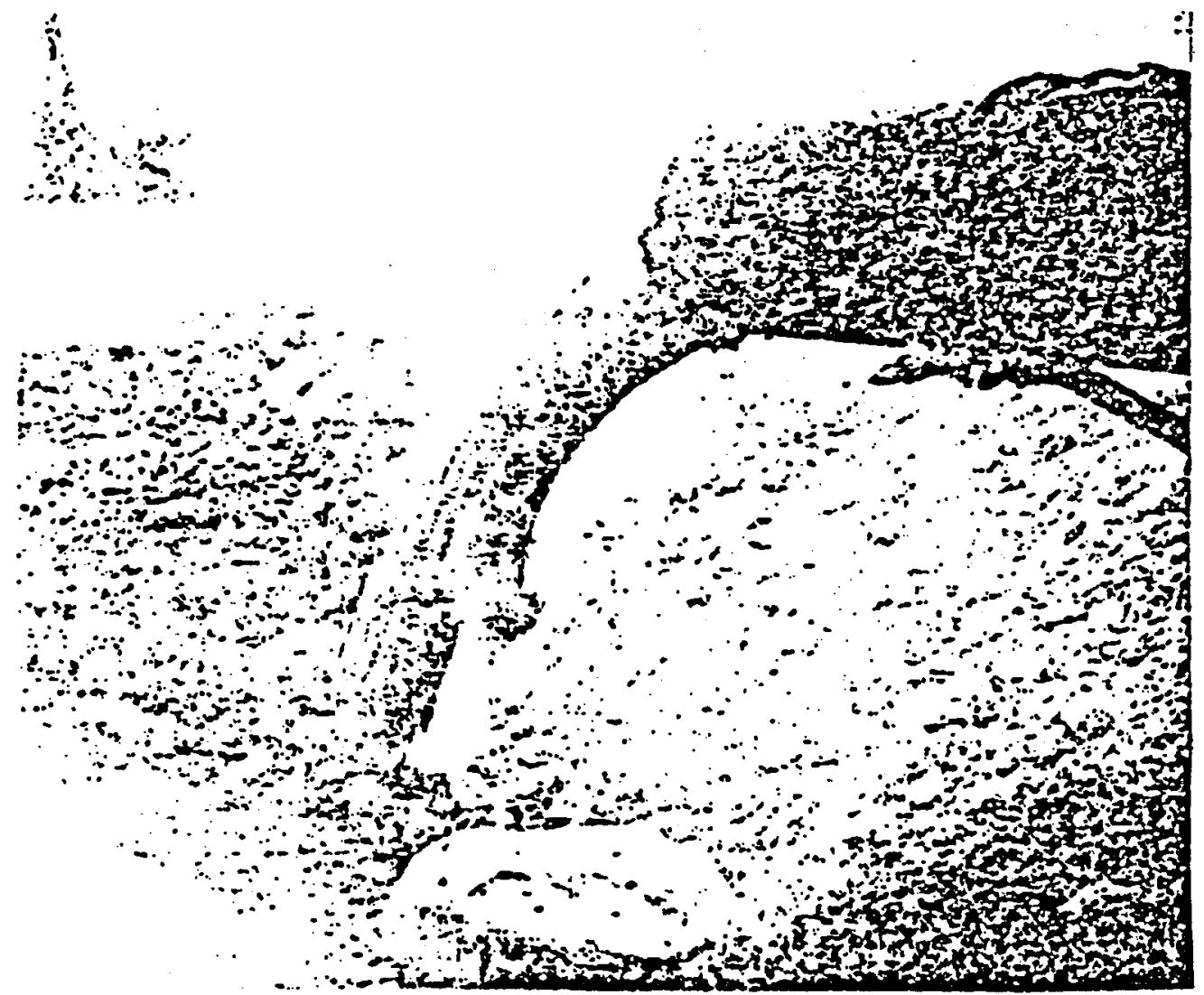

Figure 1.1. Stiff foam coming from blooie line. Notice the barrel in the foreground showing shaving cream like consistency (Anderson).

The system was stable enough to prevent formation fluids from flowing into the wellbore and yet not lose circulation. The only problem encountered was that the foam was so stable 
that it could not be broken and reused. In fact, five years later the pits of used foam were still too wet to cover as shown in Figure 1.2.

With ininer eviporation, bentonite forms - solid mon evaparesting bloritet Surfoce

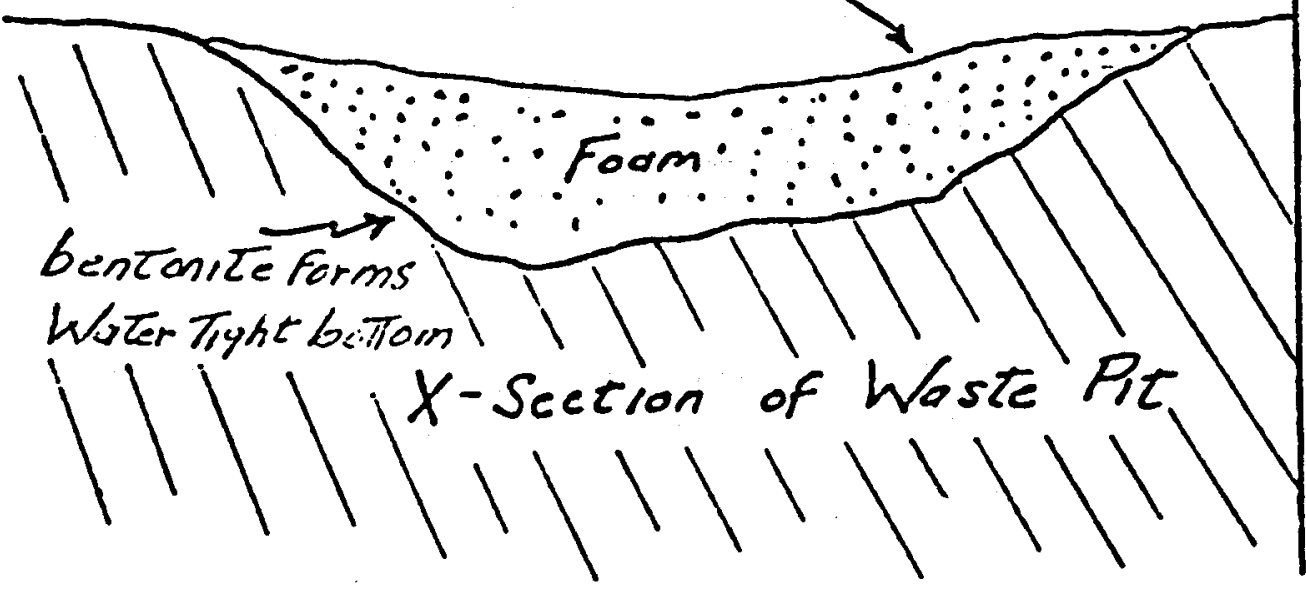

Figure 1.2. The Stabilizing and Persistent Effect of the Bentonite in Stiff Foam Discards.

\section{Depleted Reservoirs}

Since foams exert less bottom-hole pressure than water, they make excellent fluids for drilling depleted reservoirs for secondary and tertiary recovery. Standard $0 i l$ of California uses them in the workover and recompletion of the "Huff and Puff" steam flooding of the Taft Field as well as in other california fields. The fluid pressures in these depleted fields are very low (Figure 1.3). 


\section{Foam recompletions and new wells}
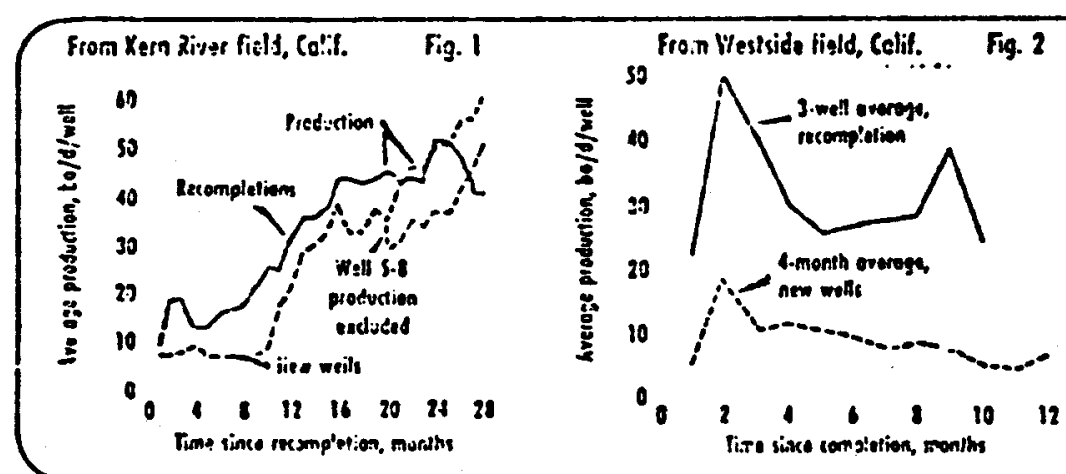

Figure 1.3. Effectiveness of Foam as a Workover and Drilling Fluid (Hutchinson).

Stiff foam is commonly used in high mesa or mountain country where lost circulation is a serious problem. A large stiff foam project is operated by the ltalian National oil Company (AGIP) in the folded zone of the Zargos Mountains in Iran. The mixtures and techniques they use are similar to those used by the A.E.C. (Figure 1.4). 


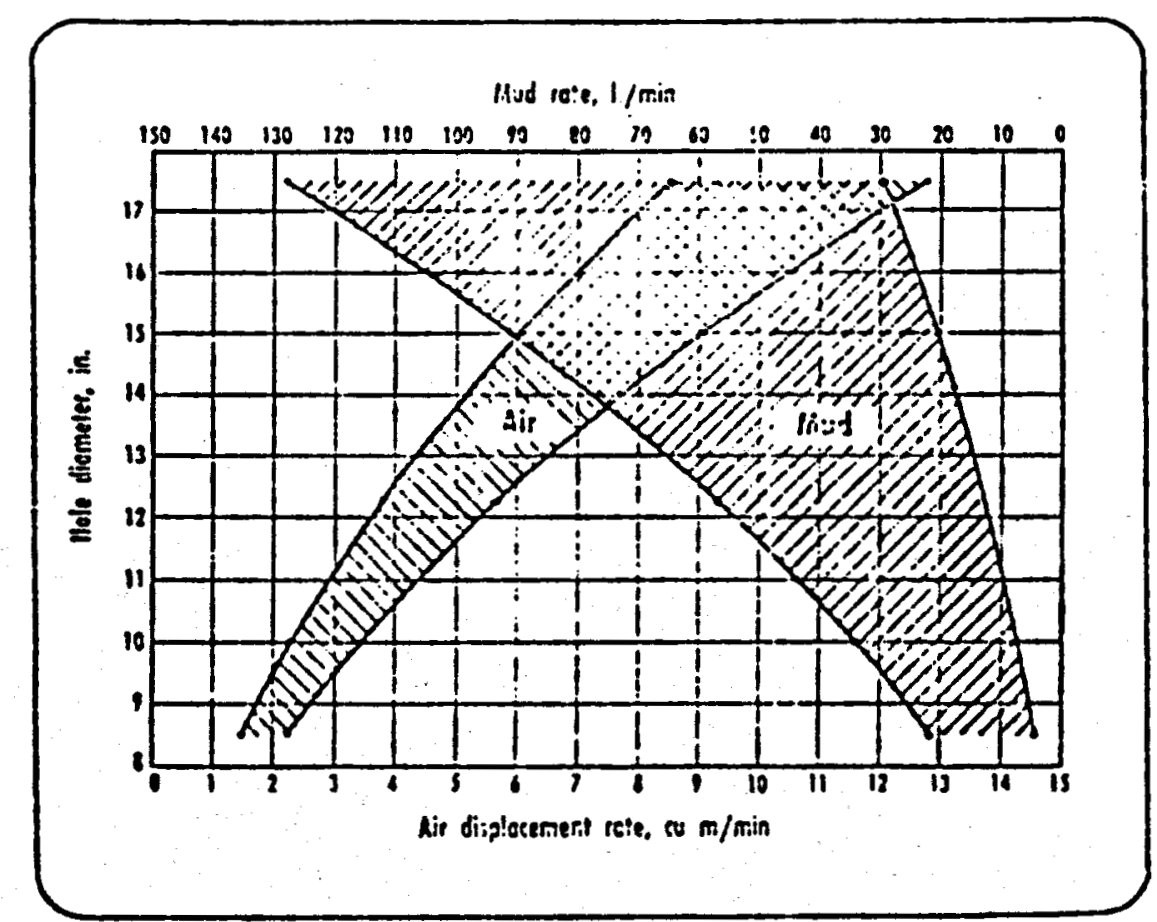

Figure 1.4. Air/Mud Ratios on Foam used by AGIP in Iran (Garavini).

One common use of foams is in drilling very large mine shafts because of its high lifting capacity.

Permafrost Drilling

Probably the most unique use of stiff foam has been to drill gauge hole through the permafrost on the North slope of Alaska (Figure 1.5). In this application, the insulating properties of the foam are particularly helpful. 


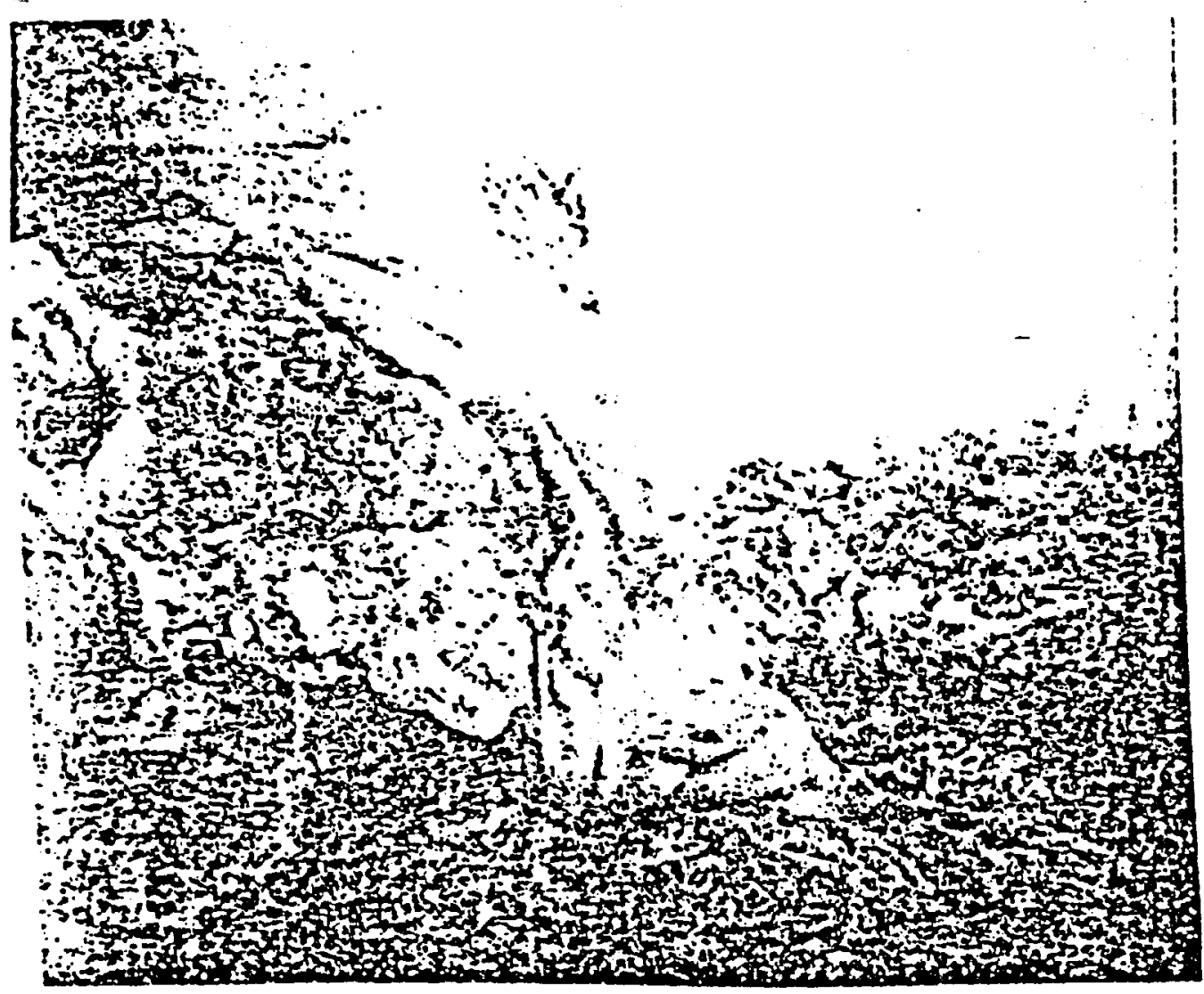

Figure 1.5. Frozen foam piles up in the sump. The 12-inch blooie line was frozen internally to an effective diameter of only 3-inches (Anderson).

Fracturing and Completions

As a completion and workover fluid the lifting capacity of the foam in laminar flow is very high. This allows the large fragments of rock and waste to be circulated up to the surface with a low circulation rate and hence a low back pressure or circulating density against the reservoir formations. The net effect of this has been that less fluid was put back into the reservoir rock and so there is a significant reduction in skin damage. 
Foam mixtures have also been used as fracturing agents because of the high lifting capacity but also because of the stored energy in the fluid. The foam expands after the fracing treatment and unloads the hole without swabbing or pumping.

\section{Geothermal Application}

Potentially foams could be used in many geothermal applications. In fact they are not commonly used, primarily because of 1) cleaning and disposal problems, and 2) corrosion. The inability to break, clean, and reuse foams significantly increases material costs.

Several companies, particularly Union and Chevron, have studied foams and have continuing projects to develop materials, procedures, and equipment for utilizing foams in high-temperature applications. 


\section{REVIEW OF FOAM DRILLING}

Foam drilling uses a drilling fluid that resembles foamed shaving cream. The foam is made up at the surface by injecting a nonionic foaming agent into a water that has been treated with lime and corrosion inhibitors The mixture as it is pumped down the hole by the mud pump is a nonfoamed water. When the mixture passes through the bit jets, it starts to expand. The expansion is governed by the downhole pressure and at the bit, the foam is essentially water. At the surface, the foam is fully expanded and contains $90 \%$ to $95 \%$ air and $5 \%$ to $10 \%$ water. Most of the expansion takes place in the upper $500^{\prime}$ to $1,000^{\prime}$ of the hole.

The advantage of foam drilling is that it produces a drilling fluid column with a variable density that can be adjusted so as to control water influx while avoiding lost returns. The density effects are shown in figure 2.1 .

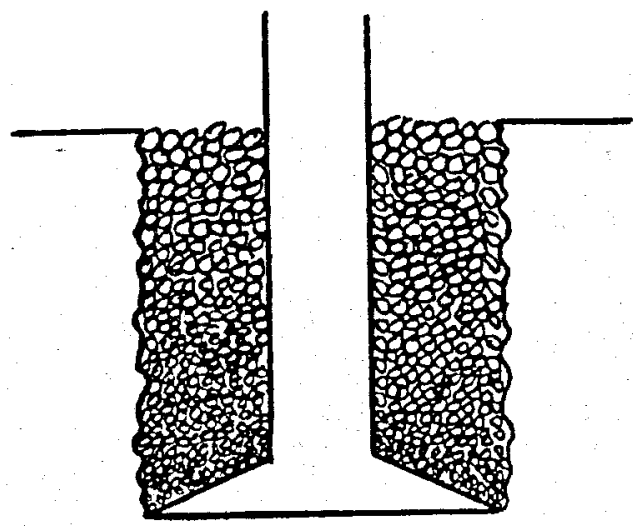

Depth

(feet)

0

1,000

2,000

3,000

4, 000

5,000

\begin{tabular}{r} 
Pressure \\
(psig) \\
\hline 0 \\
130 \\
420 \\
780 \\
1,160 \\
1,560
\end{tabular}

Figure 2.1. Typical Foam Drilling Column 
Another advantage of foam is that is provides a method of supporting the wall of the hole and significantly reduces sloughing of the hole. Under some conditions other additives can be put in the foam mixture that chemically helps reduce shale disintegration. These materials are often salts of potassium. The effective viscosity of the foam in the annulus is so high that the fodm has an excellent lifting capacity and efficiently cleans the hole.

Foam used in Alaska to drill the permafrost has provided an excellent insulating effect. It might be postulated that in very hot holes, the insulating effect of the foam might tend to stabilize the mixture against high-temperature effects and thus reduce the problem of drilling in a very hot environment.

\section{Foam Composition}

"STIFF FOAM" is a mixture of water, bentonite, carboxymethyl cellulose, and foaming agent. The general compositions are:

\section{Fresh Water}

Water

Bentonite

CMC

Soda Ash

Foamer

Water
Asbestos Fiber
Cypan
Soda Ash

Foamer

\section{$41 \mathrm{gal}$}

$12 \# / b b \mid$

$1 / 2 \# b b l$

1 \#/bbl

$1 / 2$ gallon foamer

\section{Salt Water}

\section{$41 \mathrm{gal}$}

$10 \# / b b \mid$

$1 \# / b b \mid$

$1 \# / b b l$

Cost $\$ 6.00 / \mathrm{bbl}$

12 galion 


\section{The Effect of Foam}

The problem of fracture pressures and lost circulation mandates that the density of the drilling fluid be variable. In the normal case of drilling fluids that are heavier than water, the weight of the fluid can be reduced and casing set to protect low pressure zones that will cause lost circulation. In the more fractured rocks and in areas of low water tables the average density of the drilling fluid column must be less than water to avoid lost returns. Air drilling is the ideal solution where water influx or an unstable wellbore does not preclude its use. Mist drilling, the addition of some water and detergent to the air stream extends the use of air into damp formations, but is not effective when water influx rises much above 10 gallons per minute, especially when the formations are sensitive to water wetting.

Foam provides an ideal solution in the area of water influx and sensitive formations since the foam column provides a variable density that can be controlled by the air injection rate or the backpressure on the hole.

\section{Designing the Drilling Fluid}

It is worthwhile to explain and define the effect of foam in the hole. The foamed mixture contains 5 to $10 \%$ drilling water and 90 to $95 \%$ air at the surface. The total amount of water that is used depends upon the amount of water required to clean the bit because below about 1,500' the air is compressed to the point where the air volume is less than one-tenth the surface volume.

Therefore, the first design parameter for foam is the amount of fluid required to clean the bit. This depends upon 
the rock drilled, the drilling rate, and the hole size. In a 7-7/8" hole drilled in sandstone at $10 \mathrm{~min} / \mathrm{ft}$ the volume of water required would approach $200 \mathrm{gpm}$. There is no commonly accepted term to develop these fluid volumes.

The second design parameter for foam is the reduction in hydrostatic head required. The reduction in hydrostatic head of foam follows the equation':

$$
h=\frac{1}{D}\left[P+\frac{n p}{100-n} \ln \left(\frac{P+p}{p}\right)\right]
$$

where

$$
\begin{aligned}
h & =\text { depth, ft } \\
D & =\text { hydrostatic pressure, psi, of a column } \\
& \text { of fluid one foot high with no air in it } \\
p & =\text { pressure in atmospheres at depth } h \text { due to } \\
\text { mud column only } & \text { back pressure at wellhead, atmosphere } \\
p & =\text { fraction by volume of gas in mud at } \\
\frac{n}{100} & \text { wellhead at back pressure } p
\end{aligned}
$$

Details of the calculation and typical solutions are presented in Appendix 1 .

Figures 2.2 and 2.3 are graphic examples of the effect of foam on the hydrostatic pressure. In each of these cases, the assumption is made that the foam used will be the stable Foam mixture and that the water will weigh 8.4 pounds per gallon, slightly more than pure water. Notice in the plots that the major reduction in hydrostatic pressure is in the very top of the hole. Below 1,500' to 2,000' in Figure 2.2, the foam is compressed to the point that the column is essentially a liquid column.

1. White, Robert J.: "Bottom-Hole Pressure Reduction Due to Gas-Cut Mud," AIME-SPE T.N. 4,301,957. 


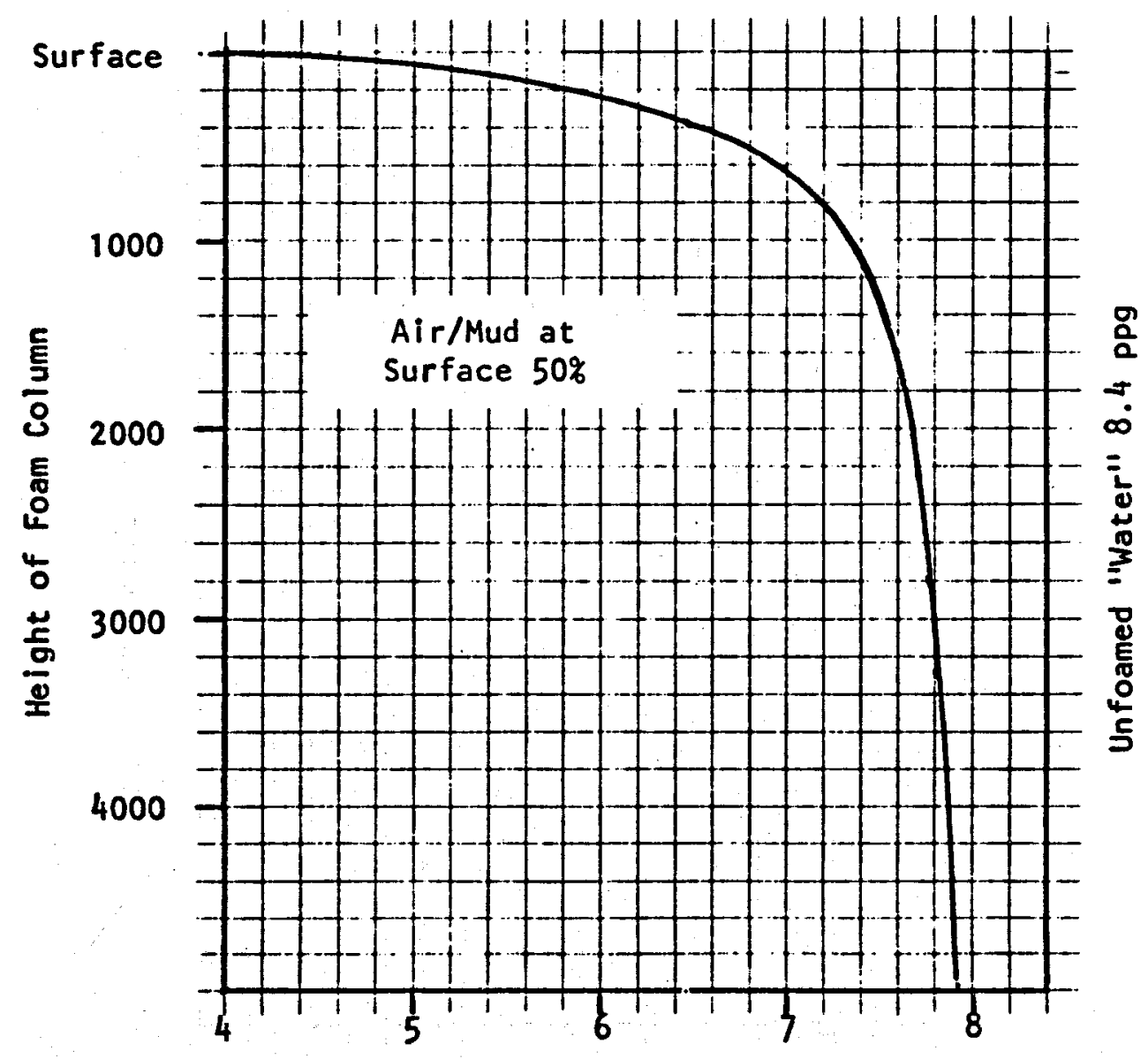

(D) Effective Foam Welght ppg

Figure 2.2. Foam Density vs Depth 
In Figure 2.3, where the surface ratio of fluid to air is 1:10 the increase in pressure of the foam column is much slower than in the $1: 2$ ratio of Figure 2.2. This illustrates the use of fluid to air ratios in controlling pressures.

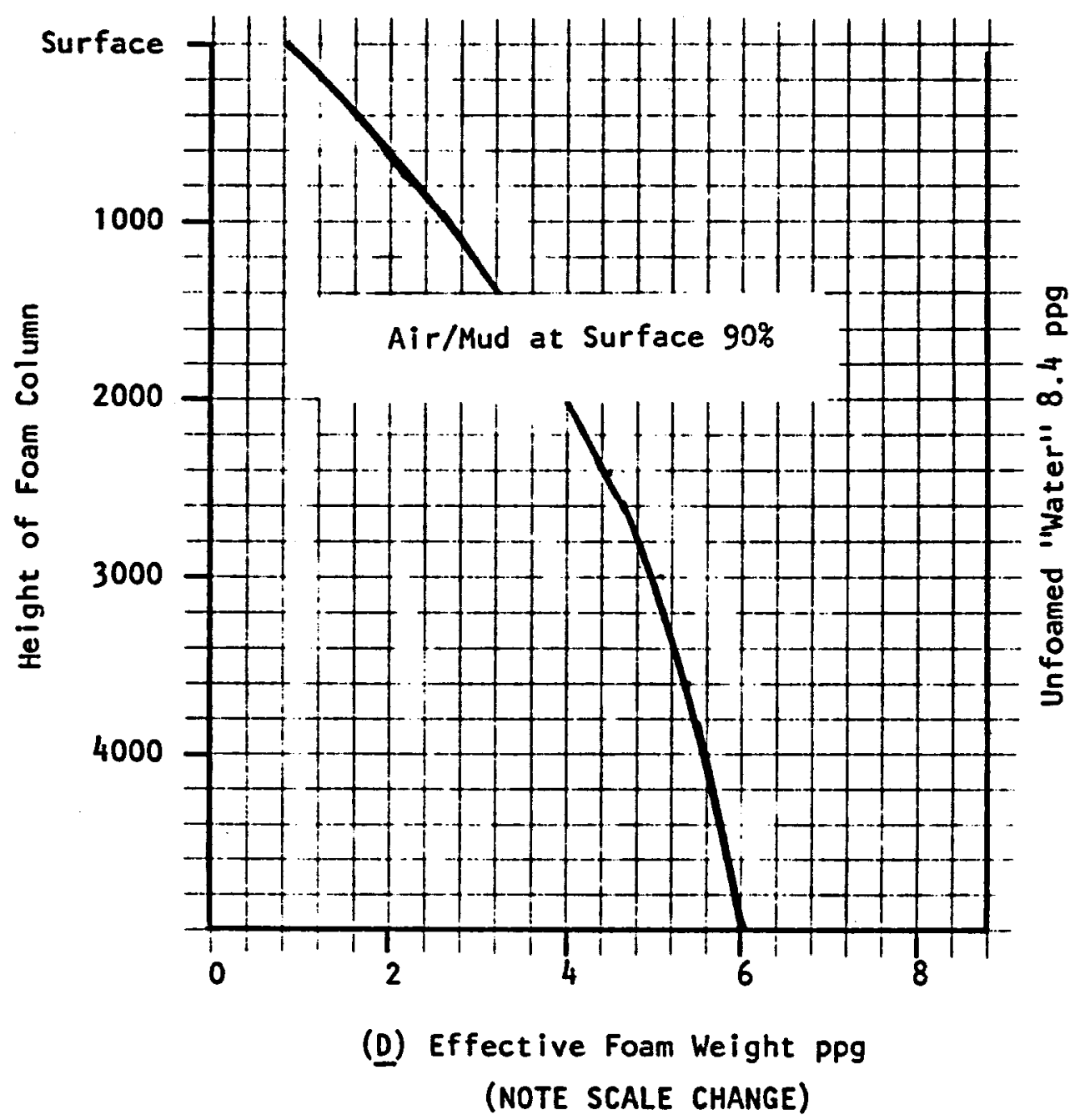

Figure 2.3. Foam Density vs Depth 
Figure 2.4 shows the effect of backpressure on the wellbore. The 100 psi backpressure is extreme for foam drilling, but it illustrates how the fluid column pressure can be increased by the use of surface imposed pressure.

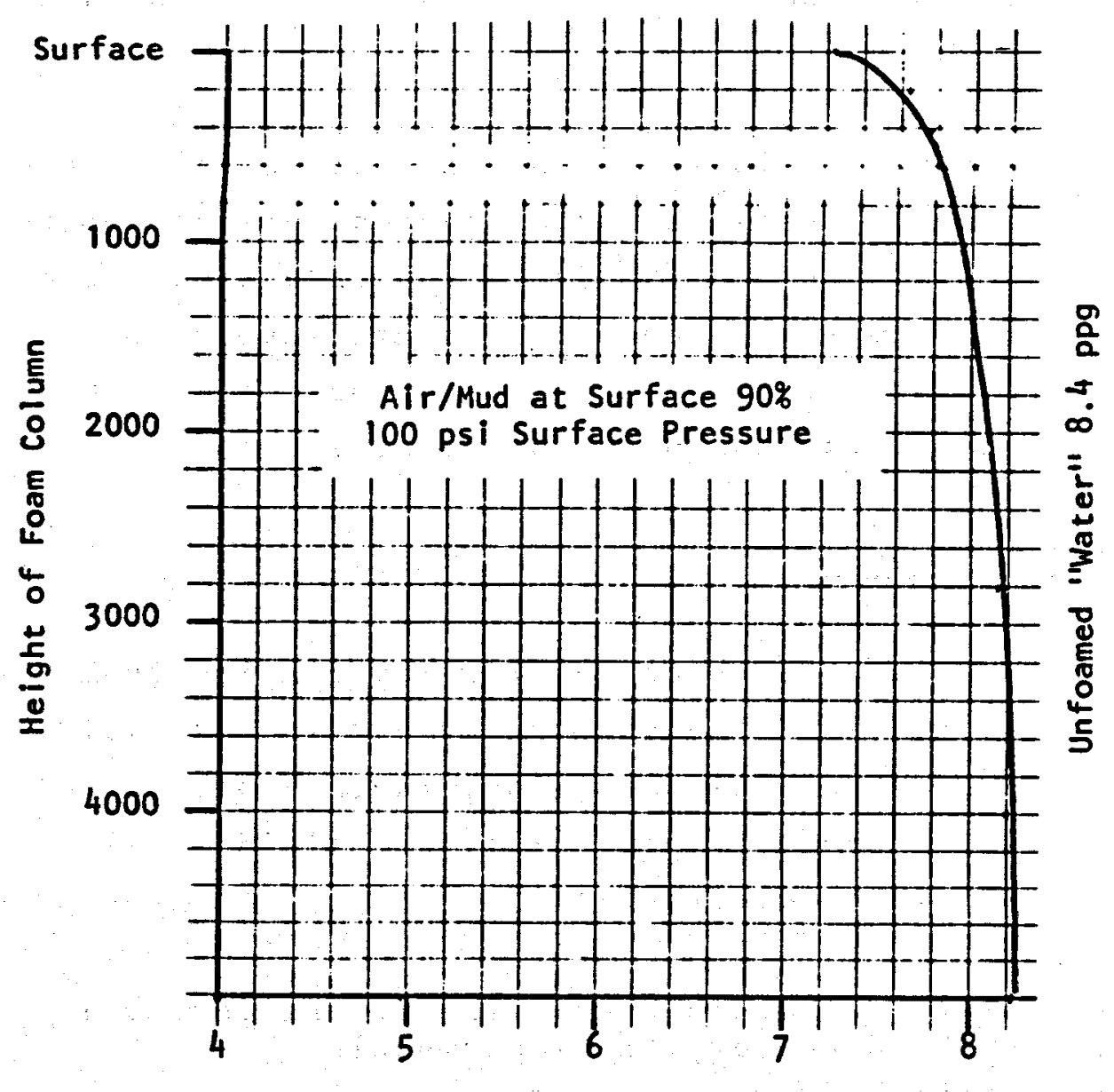

(D) Effective Foam Weight ppg

Figure 2.4. Foam Density vs Depth 
In practical application, the limit of a true air/fluid emulsion is limited to about 10:1. (This is also the limit of foam shaving creams.) More air can be added to further reduce the fluid column pressure, but the addition of air beyond the 10:1 ratio causes some heading in the foam. In most cases there is some slippage of the air in the foam at high ratios and in large holes, so that additional air, up to 20:1 must be added and some heading of the foam column is accepted.

The heading of the foam column does not appear to cause significant downhole pressure surges because of the compression effect. The actual use of foam in the hole requires some practice. As the hole size becomes larger, some adjustment of foam chemicals, air volume, and water volume needs to be made to balance out the unknowns in the hole.

When Foams Can Be Used

Drilling fluids can be categorized by density from the very heavy muds to air. The use of any particular fluid depends upon the geological conditions in the hole being drilled. For a reasonable foam drilling decision, all alternatives should be considered.

- Air Drilling. Use air drilling if the interval is very hard and dry, or impermeable.

- Mist Drilling. Use mist drilling to solve dampness in an air hole.

- Foan Drilling. Use foam drilling where formation gradients are lower than $0.4 \mathrm{psi} / \mathrm{ft}$, the hole is unstable due to fractured formations, and/or it is too wet for air drilling.

- Water is used as a drilling fluid when there is no need for the lifting capacity of viscosity, fluid loss control, or special mud weights, and the formations are not water sensitive or subject to easy erosion. 
- Aerated muds are used to solve severe lost circulation problems when using mud. It may be preferable to switch to foam.

The above items typically grade into each other as sub systems of the basic air drilling or mud drilling system.

When to use foam is often a subjective decision because of lack of information. The following descriptions help provide the background for a foam decision.

Develop a Mud Type for Each Casing Point Interval

A. Check for air drilling intervals

1. Is the rock hard?

2. Is formation pressure gradient equal to or less than .43 psi/ft?

3. Is the rock dry?

4. If mist must be used because of damp rock, is the rock water-sensitive?

5. Steeply dipping formations drill better with a hammer because of the light bit weight required. Do formations dip steeply?

6. Is the hole to be directional?

If the answers for 1 through 4 are yes, consider air drilling. If the answer to five is yes, air is particularly competitive. If ltem 6 is yes, check with a directional drilling company before making a decision.

B. Be prepared for mist drilling intervals. Mist will be used if the hole becomes damp and there are no watersensitive formations. Always have standby mist equipment available when air drilling. 
C. Check for foam drilling intervals. Foam is an air drilling technique used when there is too much water influx to handle with mist and/or the hole is unstable. For foam use:

1. Hole is wet.

2. Pressure gradient is below $.43 \mathrm{psi} / \mathrm{ft}$ or

2a. The rock is badly fractured and will not stand up and the pressure gradient is below $.47 \mathrm{psi} / \mathrm{ft}$.

Foam drilling can be overpowered by water flows, so the hydrostatic pressure needs to be balanced to avoid large influxes of water or else a mud must be used.

D. Check for conventional mud.

1. The pressure gradient is greater than .4 psi/ft.

2. The formation temperature at the bottom of the interval is less than $350^{\circ} \mathrm{F}$

or

2a. The formation temperature at the bottom of the interval is less than $300^{\circ} \mathrm{F}$ but the hole is directionally drilled, or using a packed hole assembly, or extensive testing is proposed.

E. Check for aerated mud.

1. Lost circulation occurs or may occur while drilling that cannot be solved by lost circulation material, cement plugs, or barite or gunk plugs. 
2. Mud column in the hole falls less than

$1,000^{\prime}$ when returns are lost. If mud column falls more than $1,000^{\circ}$ consider using foam, or setting plugs.

Air Drilling

Air drilling is used for a number of specific reasons.

1. The formations to be drilled are dry or impermeable hard rock.

2. The formations to be drilled are separated by casing from wet and/or permeable upper formations.

3. Drilling rate must be significantly faster than drilling with water and mud.

4. Lost circulation is a serious problem.

5. Reservoir damage may result from the use of water or muds.

As a general estimate, the following minimum air volumes are required for air drilling dry hole. Volume is listed as SCFM - standard cubic feet per minute?

$$
\begin{array}{r}
\begin{array}{r}
\text { Hole Size } \\
(\text { Inches })
\end{array} \\
\hline 6-1 / 4 \\
7-7 / 8 \\
8-3 / 4 \\
9-7 / 8
\end{array}
$$

\begin{tabular}{c} 
Air Volume \\
(SCFM) \\
\hline 1,000 \\
1,400 \\
1,700 \\
2,100
\end{tabular}

\begin{tabular}{c} 
Pressure \\
\hline 250 \\
250 \\
250 \\
250
\end{tabular}

Air volume must be metered.

2. Angel, R. R.: "Volume Requirements for Air and Gas Drilling," Gulf Publishing Company, 1958. 
Mist Drilling

Misting is an extension of air drilling used when damp formations are encountered. The same criteria as for air drilling justification are true, but in misting, detergent and water are injected into the air stream to keep damp drill cuttings from balling up or forming rings in the hole.

Air drilling costs are increased from $25 \%$ to $50 \%$ by the addition of mist because of increased air requirements, material cost, and lower penetration rate.

Lime must always be added to the injection water to maintain a $\mathrm{pH}$ of 9.5 at the blooie line. One to two pounds of lime per barrel of injected water should be used in geothermal drilling.

An amine type filming corrosion inhibitor should also be used either in batch lots or in the injection water.

Foaming agents and inhibitors must be checked with the manufacturer for temperature suitability. Use the assumed formation temperature for the interval minus $100^{\circ} \mathrm{F}$ for the suitability temperature unless large quantities of steam are being produced. If steam is produced, use formation temperature. See API RP 46, "Recommended Practices for Testing Foaming Agents for Mist Drilling." Air volume must be metered. 
Foam drilling is used when:

1. There is severe lost circulation that is difficult or impossible to control with conventional muds.

2. Air drilling is unsuitable because some hydrostatic pressure is required to stop fluid influx into the wellbore and/or fractured or broken formations make the wellbore unstable; or

3. The insulating properties of foam make it desirable.

Foams are not generally reusable and so costs for foam and air are generally quite high.

Special foamers are used for foam drilling. Two types of foam are used, "Stiff" and "Stable" foams.

Yolume Requirements

Volume requirements for foam vary appreciably, but the following air volume and air pressures should be available.

\begin{tabular}{lllll} 
Hole Size & Air Volume & Foam Mixture & Air Pressure \\
\cline { 1 - 2 } $6-1 / 4^{\prime \prime}$ & $350 \mathrm{cfm}$ & $15 \mathrm{bbl} / \mathrm{hr}$ & $300 \mathrm{psi}$ \\
$7-7 / 8^{\prime \prime}$ & $400 \mathrm{cfm}$ & $20 \mathrm{bbl} / \mathrm{hr}$ & $300 \mathrm{psi}$ \\
$8-3 / 4^{\prime \prime}$ & $450 \mathrm{cfm}$ & $25 \mathrm{bbl} / \mathrm{hr}$ & $300 \mathrm{psi}$ \\
$9-7 / 8^{\prime \prime}$ & $500 \mathrm{cfm}$ & $35 \mathrm{bbl} / \mathrm{hr}$ & $300 \mathrm{psi}$
\end{tabular}


Based on the table above and the cost of foamers, a calculation can be made of foaming costs. Foam costs do not include the cost of water or such hardware items as drilling heads.

$$
\text { Foaming Cost }=(A \$+F \$) \times T
$$

where

$$
\begin{aligned}
& A \$=\text { Air Cost per day } \\
& F \$=\text { Foam Cost per day } \\
& T=\text { Time to Drill Interval } \\
& F \$=F b b l \times(b b l / h r \times 18) \\
& F b b l=\text { Foam Cost/bbl } \\
& \text { bbl/hr }=\text { bbls per hour used }
\end{aligned}
$$

Equipment for Foam Drilling

The equipment required for foam drilling is a mixture of conventional mud drilling and air drilling equipment. Foam drilling is a compromise system that does not require the pump pressures used for mud drilling or the high volumes used in air drilling. This simplifies the equipment requirements and reduces some of the potential pollution aspects of air drilling. 


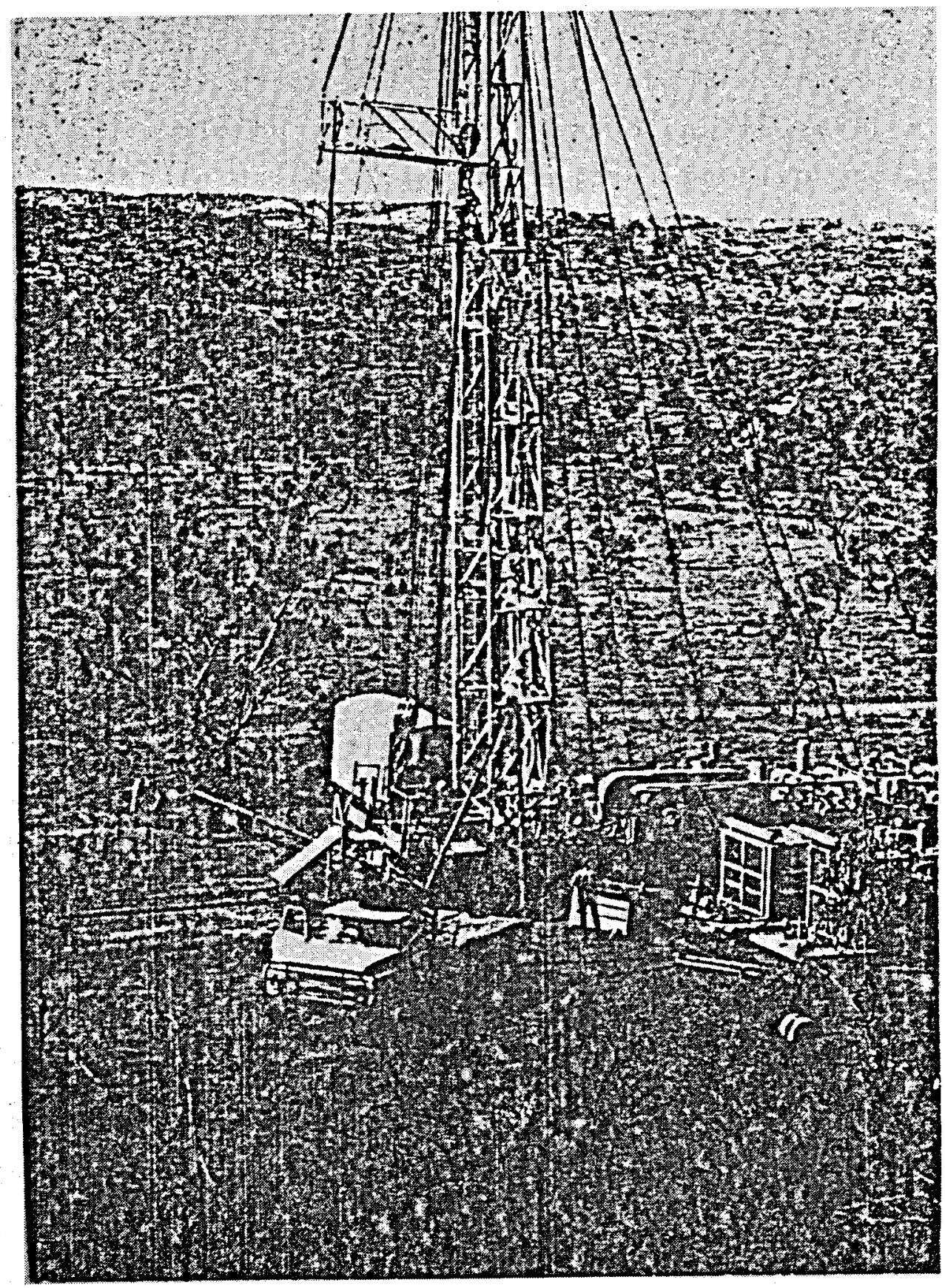

Figure 2.5. TYPICAL AIR DRILLING/FOAM DRILLING RIG (Courtesy: Interairdril. 


\section{Mud Pits}

The mud pits used with foam drilling are principally used for mixing and storage since the system is not reused. A standard system would use one 200 bbl mud pit. The first pit section would be for mixing lime and inhibitors. The back end of the pit would be suction and storage.

Mud Pump

The mud pump would be a conventional rig mud pump. A mud pump of less than 500 HP would normally be the most satisfactory because it would run fast enough to give a reasonably smooth discharge.

\section{Mixing Pump and Hopper}

A mixing pump and hopper system need to be provided in the mixing tank. The mixing pump is generally a centrifugal pump and it should have enough capacity to operate the hopper and some mixing jets.

\section{Drilling Head}

Since foam drilling is done with low pressures and volumes, any of the commercially available drilling heads are satisfactory. 


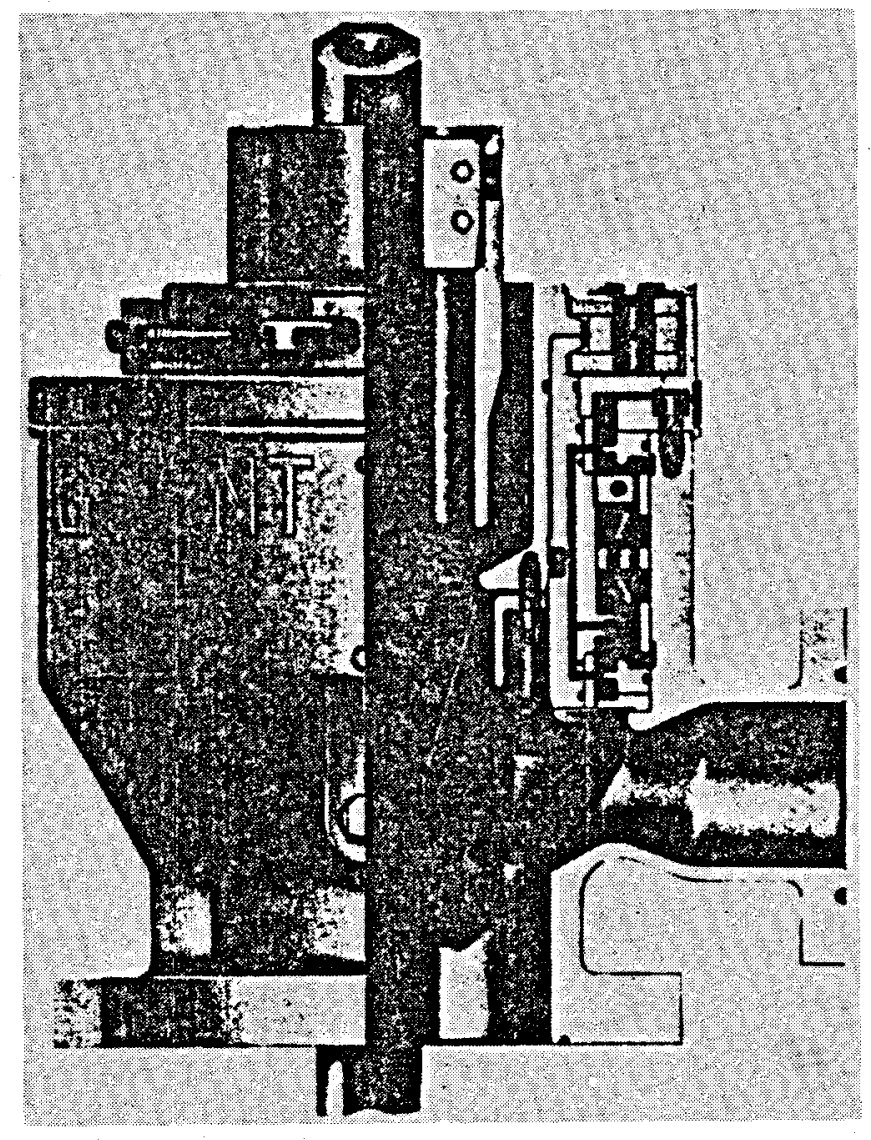

Figure 2.5. Typical Rotating Head.
Courtesy: Grant Tool Company

\section{String Float}

Foam drilling requires that a float be placed in the upper part of the drill pipe to keep the foam from expanding up the drill pipe when connections are made. A full opening float is generally the most satisfactory type since it allows the passage of wire line devices. 


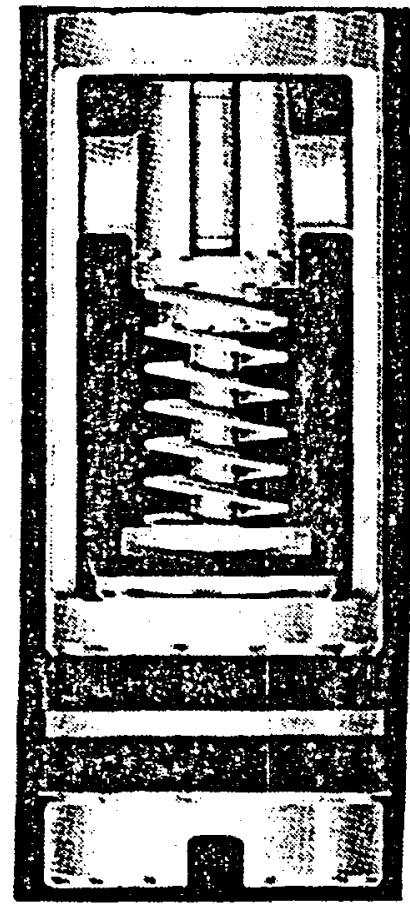

Figure 2.6. Baker Full opening Float Used as String Float.

Courtesy: Baker Tool Company

\section{Air Compressors}

The greatest reduction in air drilling costs with foam is the small volume of air required. Air volumes for foam generally are less than $500 \mathrm{cfm}$ with pressures of less than 350 psi. 
Physical Properties

Drilling foams are fcrmed by mixtures of gas, water, and certain chemicals. They vary in density from about .3 to .8 ppg depending on the amount of water present in the fluid. Other types of aerated drilling fluids would be air ( $0 \mathrm{ppg})$, mist ( 0 to $3 \mathrm{ppg})$, and aerated mud (.8 to $7 \mathrm{ppg}$ ). Figure 3.1 depicts the range of such fluids. As the density increases from 0 to 7 ppg more water and less air is combined to form a drilling fluid.

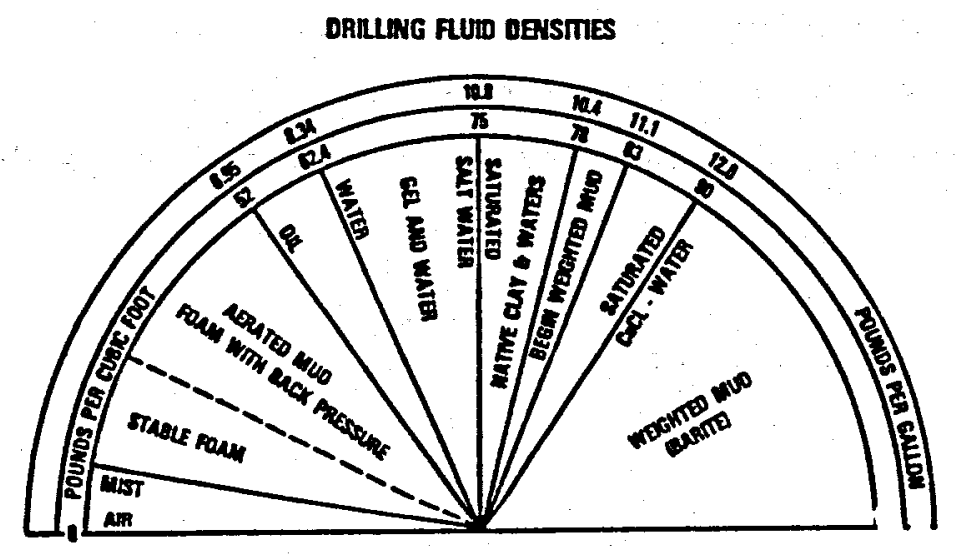

Figure 3.1. Types of Drilling Fluids and

1. Hutchinson, S. 0., Anderson, G. W.: "What to Consider When Selecting Drilling Fluids," World Oil, 1974. 


\section{Stable Foam}

Air and mist fluids differ from stable foam and aerated mud in that air is the continuous phase in the air and mist fluids and water is the continuous phase in the stable foam and aerated mud fluids. Mitchel $1^{2}$ has subdivided the second two fluids (water continuous fluids) into several regions as a function of what he terms "Quality of Foam".

\section{Viscosity Characteristics}

In Figure 3.2 , Mitchell shows the foam region as consisting of a) few bubbles dispersed in the liquid phase (low $v i s \cos i t y$ ), b) the bubble interference region (medium viscosity) and c) the bubble deformation region (high viscosity). In normal stable foam drilling operations bubble deformation exists and the foam has a viscosity between 5 and $20+c p$ with foam quality varying between .75 and .97 . Foam quality is defined by the equation:

$$
\text { Foam Quality }=\frac{v_{g}}{v_{g}+v_{1}}
$$

where

$$
\begin{aligned}
& v_{1}=\text { Volume of liquid } \\
& v_{g}=\text { volume of gas }
\end{aligned}
$$

It is the high viscosity properties of stiff foam coupled with the low density properties which make stiff foam so attractive as a drilling and completion fluid.

2. Mitchell, B. J.: "Test Data Fill Theory on Using Foam as a Drilling Fluid," 0il \& Gas Jour., September 6, 1971. 


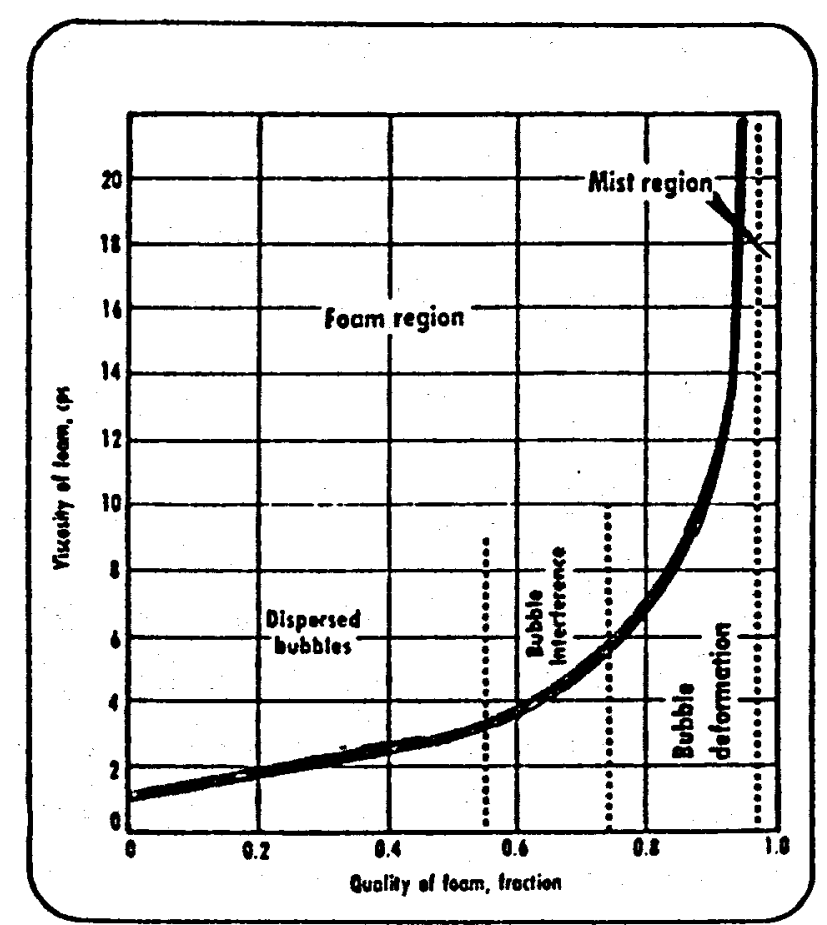

Figure 3.2. Foam Viscosity and Type as A Function of Foam Quality

It is the high viscosity properties of stiff foam coupled with the low density properties which make stiff foam so attractive as a driling and completion fluid.

\section{Density Characteristics}

The low specific gravity of the stable foams generated provides low bottom-hole pressures which prevent lost circulation from occuring in weak zones and also minimizes formation damage?

3. Hutchinson, s. 0.: "What Foam is and How 1t!'s Used," World 0il, November 1969. 
Bottom-hole pressure of only 50 psi has been measured ${ }^{3}$ at a depth of 2,900 feet. This represents an average fluid weight of $.33 \mathrm{ppg}$.

In order to insure the proper formation of stiff foams the fluids formed must have specific chemical compositions.

Chemical Composition of Foams

Stiff foams are formed by mixing a gas, water, and certain chemicals in specific proportions using special injection equipment and pumping into the well at specific rates. The type of gas, water, and foaming agent used should be lab tested to insure compatibility.

\section{Gases Used}

The two most common gases used in stable foam drilling are air and natural gas. Other gases which have been used are nitrogen, carbon dioxide, and exhaust gases. Natural gas is preferred, but air is usually used because of lack of availability of natural gas.

\section{Water Used}

When fresh water is not available, salt water or field waters can be used. When this is done, careful testing should be carried out to insure success. Water from areas such as the Imperial Valley of California contain excess salts and metals which present unique problems. 
Foaming Agents Used

In most stable foam drilling, one of several types of foaming agents are used.

1. Alcohol Ether Sulfate. These foaming agents are formed with long chain alcohol ethoxylates which are sulfonated. They are the most widespread foaming agents and can be formulated for aither fresh water or salt water solutions.

2. Alkyl Benzene Sulfonate. These foaming agents have better temperature stability than (1) above, but they are not as effective. More agent is needed per gallon of water foamed.

3. Alpha olefin Sulfonate. These agents perform very similarly to (2) above.

In each application it is necessary to determine the amount of time the foam will be in the well and the temperature of exposure before concentrations can be estimated. Usually $1 / 2$ to $1 \%$ foaming agent (by volume) is sufficient.

When corrosion is a problem, as determined by coupon tests, a corrosion inhibitor must be added.

\section{Corrosion Inhibitors}

Three elements accelerate corrosion in the drilling string (a) oxygen, (b) zarbon dioxide, and (c) hydrogen sulfide.

These three corrosive elements are usually treated 4 by raising the $\mathrm{pH}$ of the water to 10 with additions of sodium hydroxide or lime and by adding an inhibitor which forms a

4. Rehm, Bill, Air Drilling Handbook, August 1975. 
protective chemical coating. The presence of the high pH neutralizes the hydrogen suifide.

\section{Rate of Injection}

In normal operation the gas is injected with a single compressor at a rate of 350-400 SCFM at a pressure of 250-300 psi. The water/chemical mixture is injected into the mixing head with a liquid injection pump at a rate of about $20 \mathrm{gpm}$.

\section{Special Equipment}

The formation and maintenance of a stable foam requires several pieces of special equipment. These are covered in detail in previous sections of this report.

\section{Requirements for Ideal Foams}

An ideal stable foam cleans the hole, is stable at wellbore temperature, resists the effects of contamination, and is disposed of easily. In many cases, it is necessary to experiment with the local water, contaminants and gas to determine the ideal foam.

\section{Hole Cleaning}

In most cases an annular flow rate of $300 \mathrm{fpm}$ is required to provide adequate hole cleaning. Lower rates (100 fpm) have been used, but in these cases foam quality was increased by controlling foam solutions composition and gas to liquid ratios. The relative lifting force of stable

5. Petroleum Engineering: "Stable Foam Cuts Cost, Increases Production," Vol. 41, No. 13, P. 61-63, December 1969. 
foam increases as its liquid volume decreases, as shown ${ }^{1}$ by figure 3.3. Test cases have shown that considerable quantities of solids can be removed from a well using foam.

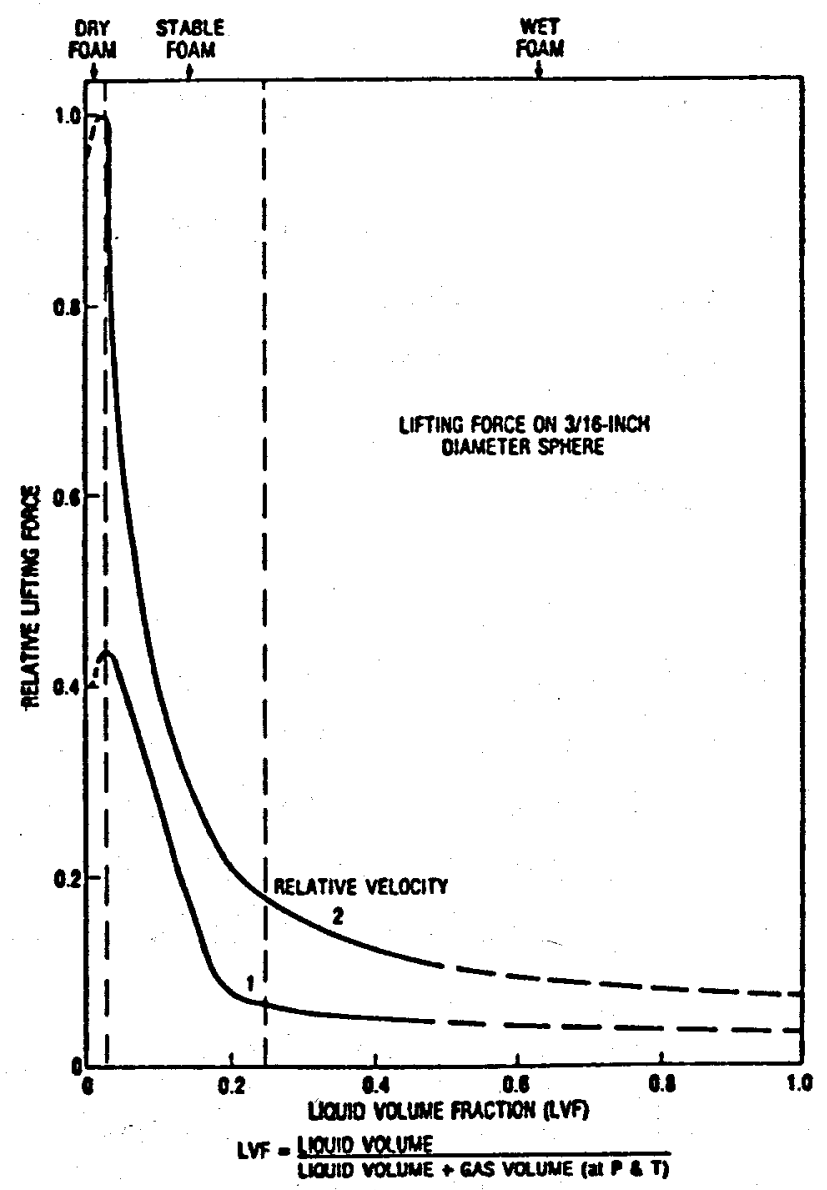

Figure 3.3. Relative lifting force of preformed stable foam (After Beyer, Millhone, \& Foote) 
In artic drilling a 17-1/2 inch hole was successfully drilled using foam at drilling rate of 35-60 feet per hour. In another test ${ }^{5}$ the carrying capacity of foam wa compared to that of salt water. The salt water was circulated at $150 \mathrm{fpm}$ and solids were removed at a rate of 16-40 Ibs/bbl of salt water. Foam was then circulated at $300 \mathrm{fpm}$ and solids were removed at 43-328 lbs/bbl.

A major requirement ${ }^{7}$ for cleaning drilled holes with foam is the formation of a stable foam which does not collapse when circulation is stopped.

\section{Temperature Effects}

A major limitation of stable foams is the temperature limits of the various foaming agents. To date very little information is available on this subject. Much research is needed to define and extend the temperature limits of foams. Experience has shown several unique uses for stable foam with regard to temperature conditions in wells.

In West Texas ${ }^{8}$ oil zones which contained paraffin have been put back on production after being completed with foams which were made with $200^{\circ} \mathrm{F}$ water.

6. Anderson, Glenn, W.: "Near Guage Holes Through Permafrost," 0 il $\varepsilon$ Gas Jour., Pp. 126-142, September 1971.

7. Jokhoo, Khem: "Aerated Foam Drilling in Trinidad," Petroleum Engineer, Vol. 48, No. 7, pps. 24-32, June 1976.

8. Bleakley, W. B.: "West Texas Workovers with Foam Gain Favor," Oil \& Gas Jour. Vol. 71, No. 11, Pp. 97-98, March 1973. 
Under arctic conditions ${ }^{6}$ the freezing of foams is prevented by the use of water containing 10-15\% salt water. If the fresh water is used, the foam freezes in a cellular state.

When bottom hole temperatures exceed $350^{\circ} \mathrm{F}$ and oils are present, air should not be used. This is to prevent fires.

A real potential exists for the use of stable foams in steam wells? The low heat conductivity of foam makes it an ideal circulating fluid.

\section{Contamination of Foams}

The technique of pre-forming foams at the surface has greatly solved the problem of foam failure by contaminants. It appears that once the foam is formed, contaminants do not destroy the foaming agents as readily. Foams have been designed to handle the following contaminants: ${ }^{5}$

1. 10-30 API Gravity Crude 0ils

2. Salt Water

3. Iron $0 x i d e$ and sulfide

4. Cement

5. Solvents

6. Caustic Solutions

7. Hydrochloric and Hydrofluoric Acids

8. Hydrogen Sulfide ${ }^{3}$ 


\section{Foam Disposal}

Foams are used in the drilling operation on ance through basis and must therefore be disposed of as they exist from the well. Several methods have been devised.

The foam is mixed with crude oil ${ }^{9}$ or salt water as it exits from the well and the foam is broken. Also, on occasion, certain chemicals can be added. If necessary these spent chemicals can be passed through an oil field heat-treater?

Under Arctic conditions ${ }^{6}$ the foam is simply allowed to freeze, then with minimal agitation the foam collapses.

9. Anderson, G. W.: "Foam Disposal--Offshore and Urban Operations," Chevron Research Company Foam Cleanout Technical Notes, April 1977. 
IV APPLICATION OF FOAMS IN GEOTHERMAL DRILLING

Drilling fluid related problems are the single most frequently sited reason for drilling problems in geothermal wells. The most apparent problems are the failures of the fluid to perform essential functions under high-temperature conditions. For example, gelation of conventional muds when circulation is stopped for operations other than drilling can lead to stuck pipe, aborted logging runs, stuck tools, etc. The related high pumping pressures can cause unexpected failure of casing seats or formation breakdown with consequent loss of circulation. Fluids formulated to remain reasonably stable at higher temperature do not have adequate filtration characteristics, resulting in formation damage.

Less obvious are the high direct costs which can be incurred with geothermal drilling fluids. Expensive treatment and replacement of materials is required to keep the fluid properly conditioned. Difficulties in corrosion control in geothermal environments lead to more frequent drill pipe replacement and drill pipe related problems than is experienced in non-geothermal applications.

Least obvious is the indirect cost from slower drilling, lost time for peripheral operations such as mixing mud, adding lost circulation materials, drill pipe inspection, etc.

As discussed in the review of foam drilling, the selection and use of drilling fluids for geothermal application requires greater care and technology than ordinary oil and gas operations. The high cost of these operations and the sensitivity of geothermal formations to irreparable drilling damage to productivity necessitates improvements in the effectiveness of drilling fluids in geothermal applications. 
A three element approach was used in examining the potential of drilling foams for reducing the cost of geothermal wells. First, an extensive survey of industry personnel was made to a) develop an overview of the extent of which foams are applicable to geothermal drilling and b) to determine the problems associated with using foams. second, to examine laboratory procedures for screening foam drilling fluids and to measure properties of typical candidate materials. Third, to recommend a program for improving drilling foams and their application in geothermal wells.

\section{A. Survey}

Over fifty industry technical personnel were contacted regarding drilling foams during the course of the study. A partial list of these is included in Appendix 4 along with summaries of questions posed to these individuals, and a sampling of responses received.

The most important conclusion drawn from this survey is that drilling foams are applicable to a significant part of geothermal drilling. Several knowledgeable people estimated as high as 70 to 80 percent of geothermal drilling could be done with foam with the majority agreeing that in excess of a third and perhaps a half of geothermal drilling will be done with foam if technical problems can be solved. Cost reduction estimates ranged from 98 percent saving on drill pipe wear down to 20 percent saving on lost time cost. Estimates were that foam would be slower than air drilling but 3 to 5 times faster than drilling with muds. Foam would definitely replace air if the technical problems are solved.

Using very conservative assumptions, according to our survey, estimates of cost benefits for improved drilling foams were made. As shown in Figure 10, improved 
drilling foams could directly account for a 3 percent reduction in geothermal well cost by 1986. This would result in almost a thirty-fold payback of the investment to develop this technology by 186 .

\section{HIGH TEMPERATLRE DRILLING FOAMS}

BENETT ESTIMATES

- appLCable to 35\% of hole

- applacable to ax of well costs

- COST REDUCtón is zor

- BENERTS BEgW accRUING WN 1981

- PROGRAM COMPLTE EY 1986

HIGH TEMPERATUAE ORILUNG FOAMS

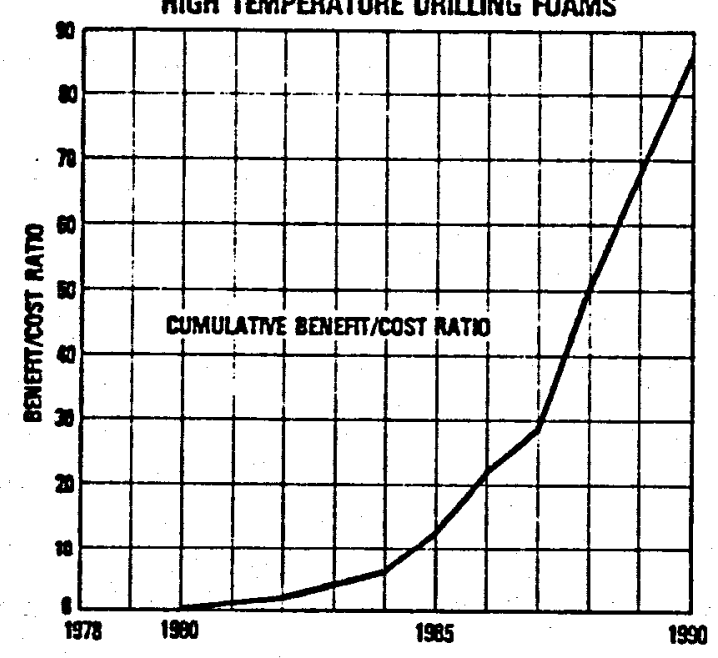

Figure 4.1. Conservative Estimate of Benefit/Cost Payout of Improved Geothermal Drilling Foam Development Program. 


\section{B. Technical Problems}

The technical problems limiting present use of drilling foams are as follows (not in order of priority):

1. Stability of foams under changing pressure and temperature conditions

2. Stability of foams under water or brine intrusion

3. Corrosivity of foams, including pH stability

4. Foam breaking, cleaning, and disposal problems

5. Borehole stability in the presence of foams

6. Sensitivity of foams in inert or stack gas with hydrocarbon impurities

7. Foam generators and other surface hardware

8. Lifting capability of foams

9. Heat transfer/insulation and heat capacity of foams

10. Testing and screening procedures for foams

Temperature stability of foaming agents was discussed with Fred Fowkes at Le-High University. He felt that no insurmountable technical barriers existed and that a hightemperature foamer could be developed with good corrosion and physical stability properties. He recommended a binary system be considered; in this syste, one component would be effective at low temperature, the other at high temperature. Similarly other technical people felt that the development of the requisite drilling foams was a matter of a systematic laboratory and field development program. The estimated time and financial budgets for such a program are presented in Chapter VII. 


\section{Testing of Foams}

Test procedures and testing of foams are included in separate sections of this report. Summarizing, however, it appears that a modified chevron test on foams (with testing before and after high-temperature aging) is probably the best presently available screening technique. Advanced testing methods including a high-temperature, highshear circulating flow loop is needed to test candidate foams under borehole conditions. The problem of ascertaining borehole stability in the presence of foams should also be addressed. Methods of breaking and cleaning foams will probably have to be tested on a field scale.

\section{Non-technical Problems}

It was evident in the interviews that non-technical considerations now limit the extent of which drilling foams are used in geothermal applications. The first of these is lack of technical expertise in their use and familiarity with their capabilities. Although several excellent papers have been written on the use of foam in workover operations discussions of drilling foams is less comprehensive. Also possibly impeding the use of foams is a lack of availability of reliable equipment for major drilling operations. All present economic incentives to use foams are reduced because present operating procedures entail having foam drilling as essentially an add on expense to air drilling operations.

\section{Summation}

There is a strong consensus that drilling foams will be widely applicable for geothermal drilling. Advantages of foam include: 
- Good Hole Cleaning

- High Drilling Rate

- Reduced Lost Circulation Problems

- Potential High-Temperature Capability

- Reduced Capital Cost

The disadvantages of mixing, breaking, and disposal along with corrosion and borehole stability have limited present applications.

Although Union and Chevron both have significant efforts directed toward developing improved drilling foams, it does not appear that there is any comprehensive effort towards solving the technical problems. Noticeably absent in the technical development were the service companies which typically have led in the development and marketing of improved drilling services.

Several individuals stated that due to the lack of effort in this area, government RED could play a particularly significant role in advancing technology without threatening the competitive structure of private industry. 


\section{Borehole Environmental Zones That Favor Foam as a Drilling Fluid}

There are four classifications of borehole environments that are appropriate for using foams. These are:

1. Lost Circulation Above Permeable Rock

2. Dry Fractured Rock

3. Hot Lost Circulation

4. Variable Density Requirements

The shallowest and coolest environmental zone that favors the use of foam as a drilling fluid is in the upper section of the hole where the temperature does not exceed $250^{\circ} \mathrm{F}$. Foam would be the favored drilling fluid if the rock was wet and fractured or had a lost circulation zone above a wet zone with a water drive. The water in the zones would preclude the use of air as a drilling fluid. The water in the zones would preclude the use of air as a drilling fluid. The compressible nature of the foam system would make it possible to have a light fluid at the top of the hole so as to avoid lost circulation and a denser fluid below that zone to repress the water flow. (See Appendix A--Foam Mathematics.) Figure 4.2 shows a schematic of this borehole situation. 


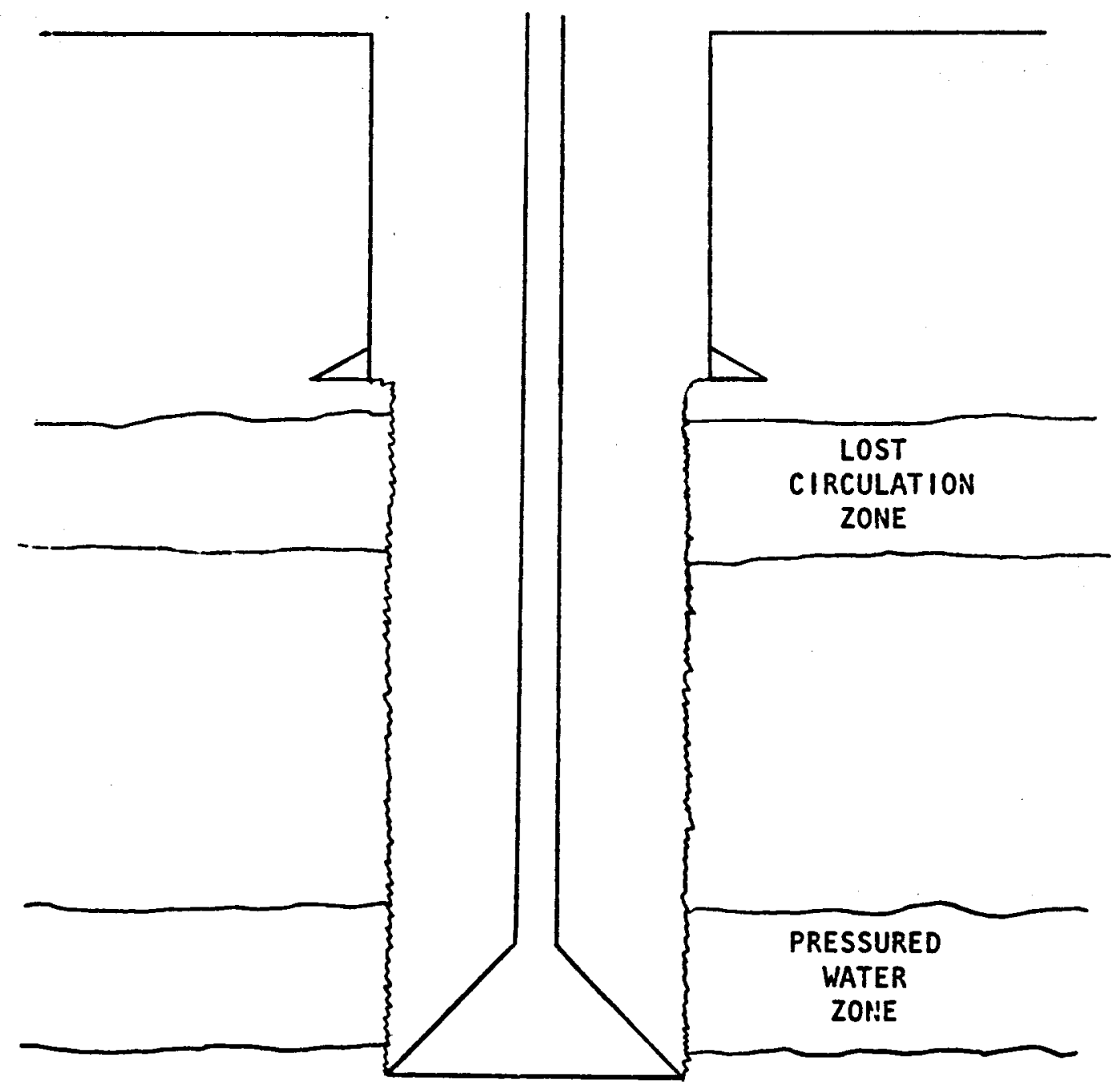

Figure 4.2. Foam Utilization Where Lost Circulation Occurs Above a Permeable Pressure Water Zone 
In dry rock, foam would be a favored drilling fluid in the section of the hole below $250^{\circ} \mathrm{F}$, if the rock is extensively fractured. The fracturing may be of the nature that normal drilling fluids would lose circulation, and air drilling would not support the walls of the hole which were extensively fractured and fragmented. (See comments on lifting capacity of foams in chapter 1.) Figure 4.3 indicates the borehole environment where foam can be used to support the walls of a fractured zone.

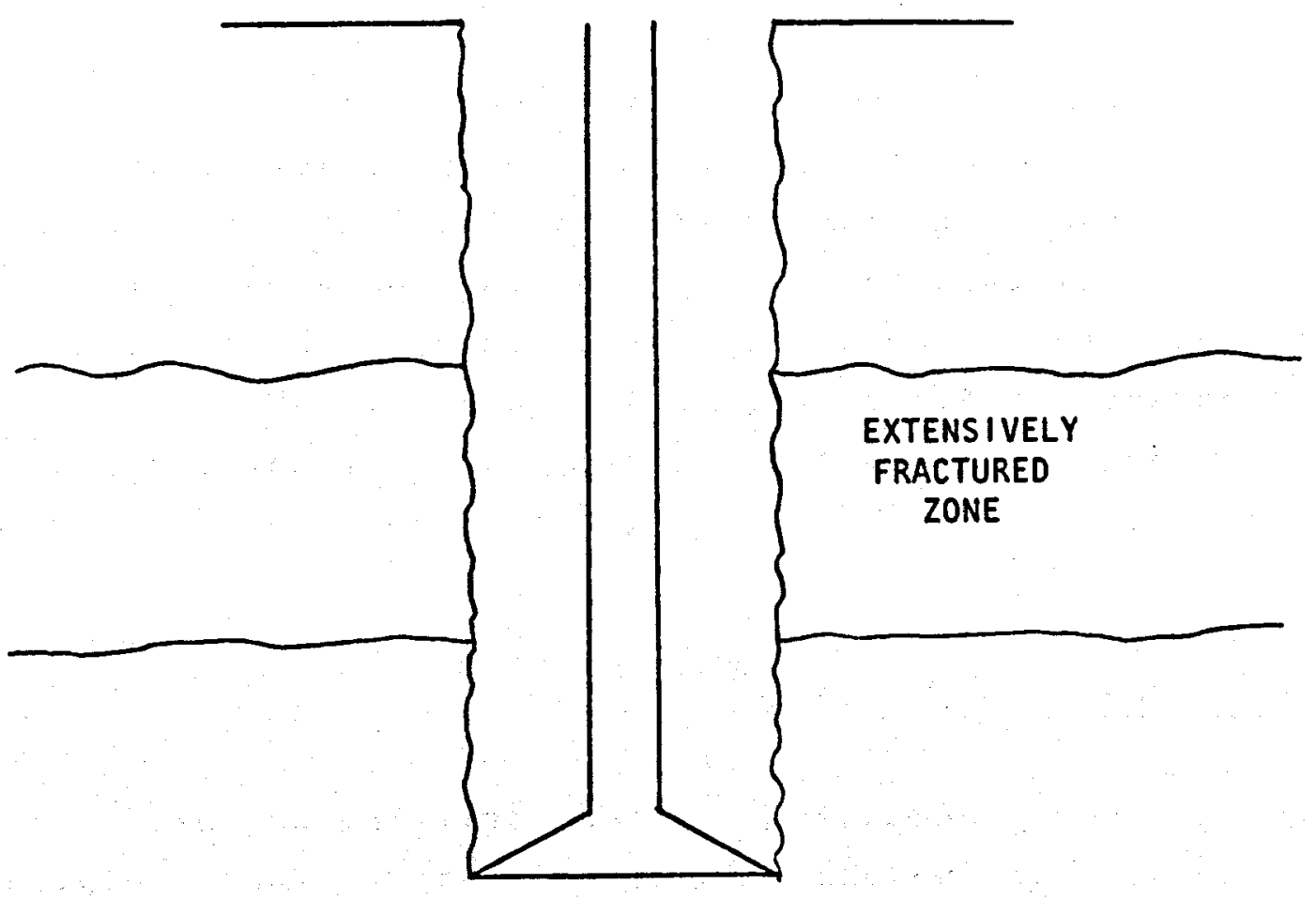

Figure 4.3. Use of Foam to Support the Walls of a Fractured Zone 
In shallow holes above $250^{\circ} \mathrm{F}$ where there was extensive lost circulation foam would be a favored drilling fluid, wherever there were formations with a water drive that precludes the use of air drilling. The variable density of the foam system as outlined in Appendix $A$ on Foam Mathematics allows a system to be built that can circulate and still repress most of the water drive. Foam systems can be built that will not go flat under the influence of reasonable amounts of water, so that the drilling system can achieve a practical balance. In hot systems of this nature, the insulating effect of the foam would tend to keep the hole from steam unlaoding during non drilling periods.

In deep holes, foam acts as a conventional driling fluid at the bottom. of the hole due to the compression of the air. The air expands at the top of the hole and thus effectively relieves the pressure on the upper part of the borehole by a greater percentage than on the bottom of the borehole. Figure $2.2,2.3$, and 2.4 in Chapter 11 show that the effective foam desnity is drastically reduced near the surface.

Equipment for Foam Drilling

The equipment necessary for foam drilling can be obtained from conventional air drilling operations equipment.

\section{Air Compressors}

The air compressors necessary for foam drilling fall within the range of the smaller air compressors available for air drilling. The equipment is effective and available. 


\section{Pumps}

The mud pumps necessary for foam drilling are available on the smaller rigs or from the equipment rental companies. Small duplex or triplex pumps in the $500 \mathrm{hp}$ range and capable of pressures to $1,000 \mathrm{psi}$ and volumes of up to 7 bbl per minute fulfill most foam drilling requirements.

\section{Foam Mixers}

The foam is mixed below the air compressor and before going down the drill pipe. There are several mixing designs available, most use a venturi effect to jet the liquid into the compressed air column. These are relatively standard pieces of piping, are easy to build, and normally available from the compressor operator.

\section{Air/Mud Meters}

The mud meter most commenly used is the Halliburton "spinner" which is normally used to measure the volume of cement slurries. It has a certain amount of wear and inaccuracies. The reciprocating mud pump is almost as accurate at the spinner, so mud flow rate measurements are available. Air volume measurements are usually made with a differential plate in the air line and a differential air meter at the compressor. This is a poor system because it does not allow a direct readout of the air entering the hole. Better readouts that directly read air volume are available and should be used. 
The only equipment that is not available at the present time is a device for breaking the foam so that the liquid can be disposed of or cleaned and remixed to foam again. Foam is used on a once through basis which adds significantly to the cost of using foam. Since the material is discharged as a persistent foam, there are areas where it cannot be used because it cannot be pumped, moved, or cleaned up until the foam breaks.

There has been very little effort made to break drilling foams. They are not pollutants in the chemical sense and so are allowed to lie in the pits until they eventually disappear. In some areas this can take years.

A major improvement in the use of foam drilling fluids would be the ability to break the foam and reuse the chemical and inhibitors. The foam is persistent and has a density of about $I$ ppg with the appearance of foaming shaving cream. It is difficult to transport to any particular point because it cannot be pumped or shoveled. It can sometimes be handled by vacuum truck with difficulty. Because of these problems and because the foam has generally been used in desert or arctic areas, there has been little done to develop methods of reusing the foam or simply breaking. it for disposal.

Operational Environments for Foams

\section{Available Foams Fresh Water}

The present foam systems are effective in fresh water environments below a temperature of $250^{\circ} \mathrm{F}$. The foam is stable and persistent. Water dilution from subsurface water flows acts only to reduce the quality or percent air in the foam. 


\section{Available Foams Salt Water}

Present foam systems are partiy effective in salt water systems. In general, as the salt or mineral content of the water increases, the foaming agent becomes less effective and more foaming agent must be used. With saturated subsurface waters, the foam tends to go flat and lose its foaming ability. At present the most effective technique to deal with this problem is to make the foam with fresher water and to maintain enough foam head against the formation to repress the formation water drive. More effective foams or foaming agents need to be developed for high salt water systems.

\section{Hot Fresh Systems}

At temperatures above $250^{\circ} \mathrm{F}$, the fresh water foams generally become ineffective as the foaming agent is broken down by the heat. Only one material was effective at $500^{\circ} \mathrm{F}$ and that was the only solid foaming material tested, sulfotex LAS 90. It is then both possible and practical to build high-temperature drilling foams that will have high lifting capacities and variable column density.

\section{Hot Saline Water Systems}

At high temperatures, it appears that there is no foaming agent available that is effective in saturated or near saturated saline water systems. This poses two limitations to the continued development of foam systems. 
a. Water influx into the bore will flatten

a foam and make it impossible to regain circulation from the bottom. The bit will have to be pulled up and circulation regained above the saturated water flow and then try to foam the head of it off going back in the hole. Experience indicates that this is easier to say then to do and causes great operation difficulties.

b. The foaming agent must be made up with fresh water. In many of the potential areas where foam would be a favored drilling fluid, saline or saturated water is available, but fresh water is very expensive. One of the major limitations to previous uses of foam and to the use of mist chemicals with air drilling has been the necessity of using fresh water. To the degree that the hole stays cool, this problem has been solved at least in part. High temperature, however, flattens all of the foams and makes all known foaming agents ineffective in saturated saline and chemical systems. 
INTRODUCTION

Foams were generated by the two following basic methods in this evaluation:

1. By injection of water solutions of the foamers into an air stream in a column

2. By aggitation of water solutions of the foamers with a high speed mixer

Liquid carry-over was measured in the column test. Foam volume (quality) and drainage time were measured on the foams generated with the high speed mixer. Foams were generated with eight of the commercial foamers which were submitted. Tests were performed with the foamers, as received, and also with the foamers which were exposed to $500^{\circ} \mathrm{F}-375$ psi for 16 hours. A standard ten foot API column was compared with a five foot column:

Other properties of the foams which were measured included corrosion rate, $\mathrm{pH}$, and surface tension. These tests were run on water solutions of the foamers, as received, and after exposure to $500^{\circ} \mathrm{F}-375$ psi for 16 hours.

\section{Column Tests}

\section{Liquid Carry-Over by $0.15 \%$ Foamer in Distilled Water}

Initially, all of the commercially available foaming agents which were tested removed large amounts of liquid from the five foot column as shown in Figure 5.1. Textilana's Sulfotex LAS-90 and Baroid's Surflo $\$ 375$ removed approximately 15\% more liquid from the column than the other foamers which 
Liquid Carry-over From A 5 foot Column Containing $0.15 \%$ Foamer In Distilled Water $\square$ - Initial

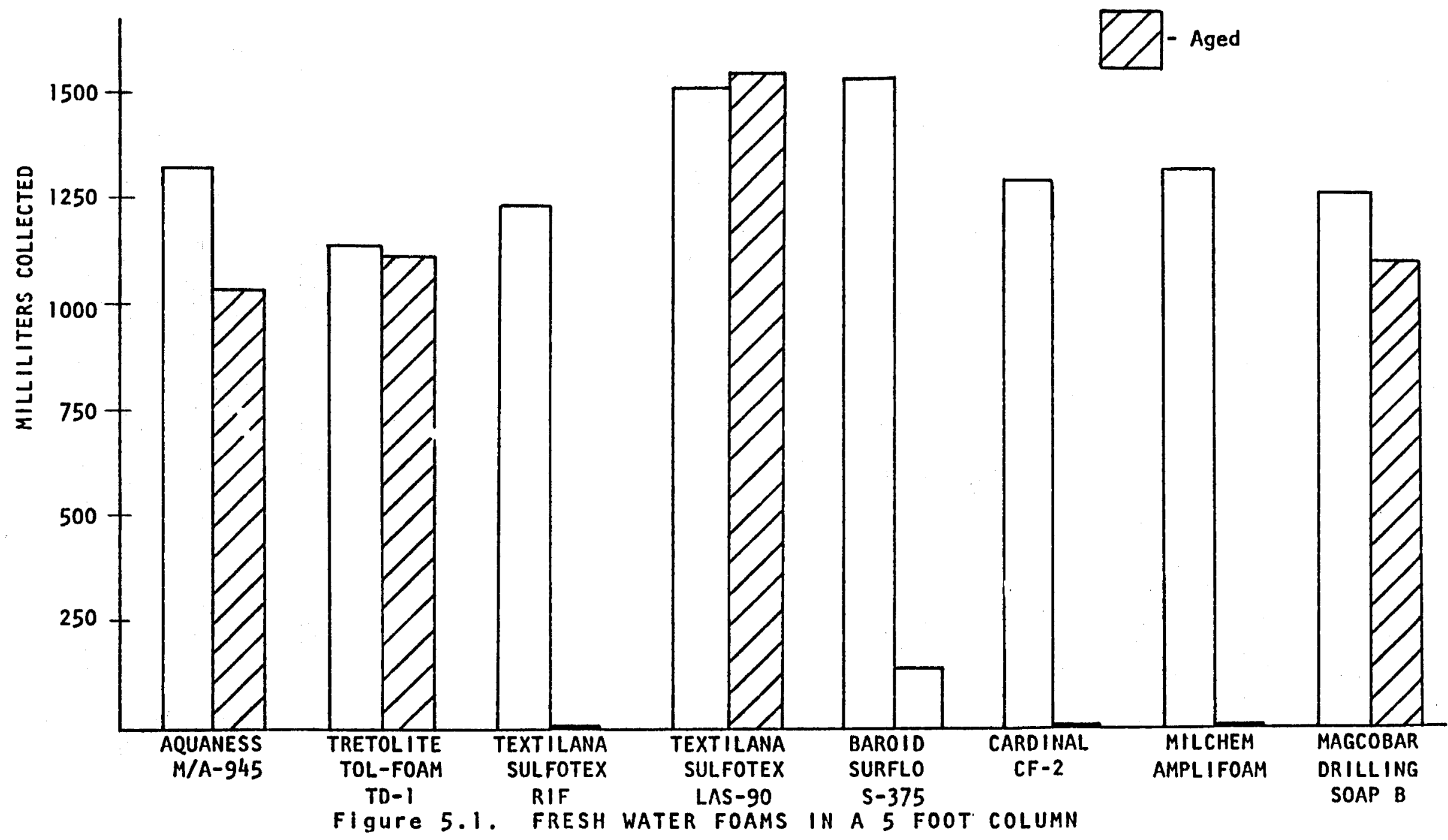

C 
were tested. Textilana's Sulfotex RIF coated the lucite column with an oily film that was difficult to remove.

After aging at $500^{\circ} \mathrm{F}-375$ psi for 16 hours, Textilana's Sulfotex LAS-90 removed about the same amount of liquid from the five foot column as before. Tretolite's Tol-Foam. TD-l also removed nearly as much liquid after exposure at $500^{\circ} \mathrm{F}$ as before but again the amount was approximately $15 \%$ less than that removed by the Sulfotex LAS-90. Textilana's Sulfotex RIF, Cardinal's CF-2, and Milchem's Amplifoam did not foam after aging at $500^{\circ} \mathrm{F}$. The other materials which were tested foamed, but a much smaller amount of liquid was removed by these foamers after exposure to $500^{\circ} \mathrm{F}$.

Similar trends were observed on tests conducted with a standard ten foot API column as shown in figure 5.2. The foamers which removed the largest amounts of liquid on the five foot column also removed the largest amounts of liquid on the ten foot column. Initially, the amount of liquid removed by Textilana's Solfotex LAS-90 and Baroid's Surflo $\$ 375$ was $20 \%-30 \%$ higher than that removed by the other foamers. only liquid and no foam was collected at the discharge port when Tretolite's Tol-foam To-l was tested. The size of the bubbles formed by Cardinal's CF-2 on the ten foot column were much smaller than those formed by the other materials. Generally, a smaller volume of liquid was removed from the ten foot column than from the five foot column.

After aging 16 hours at $500^{\circ} \mathrm{F}-375$ psi, Textilana's Sulfotex LAS-90 removed as much 1 iquid as when tested initially. Textilana's Sulfotex RIF, Baroid' Surflo $\$ 375$, Cardinal's CF-2, and Milchem's Amplifoam failed to remove any liquid from the ten foot column after being exposed to $500^{\circ} \mathrm{F}$. The remaining materials removed some liquid from the ten foot column after being exposed to $500^{\circ} \mathrm{F}$, but their ability to remove liquid was severely reduced. 
Liquid Carry-over From A 10 Foot Column Containing $0.15 \%$ Foamer in Distilled Water

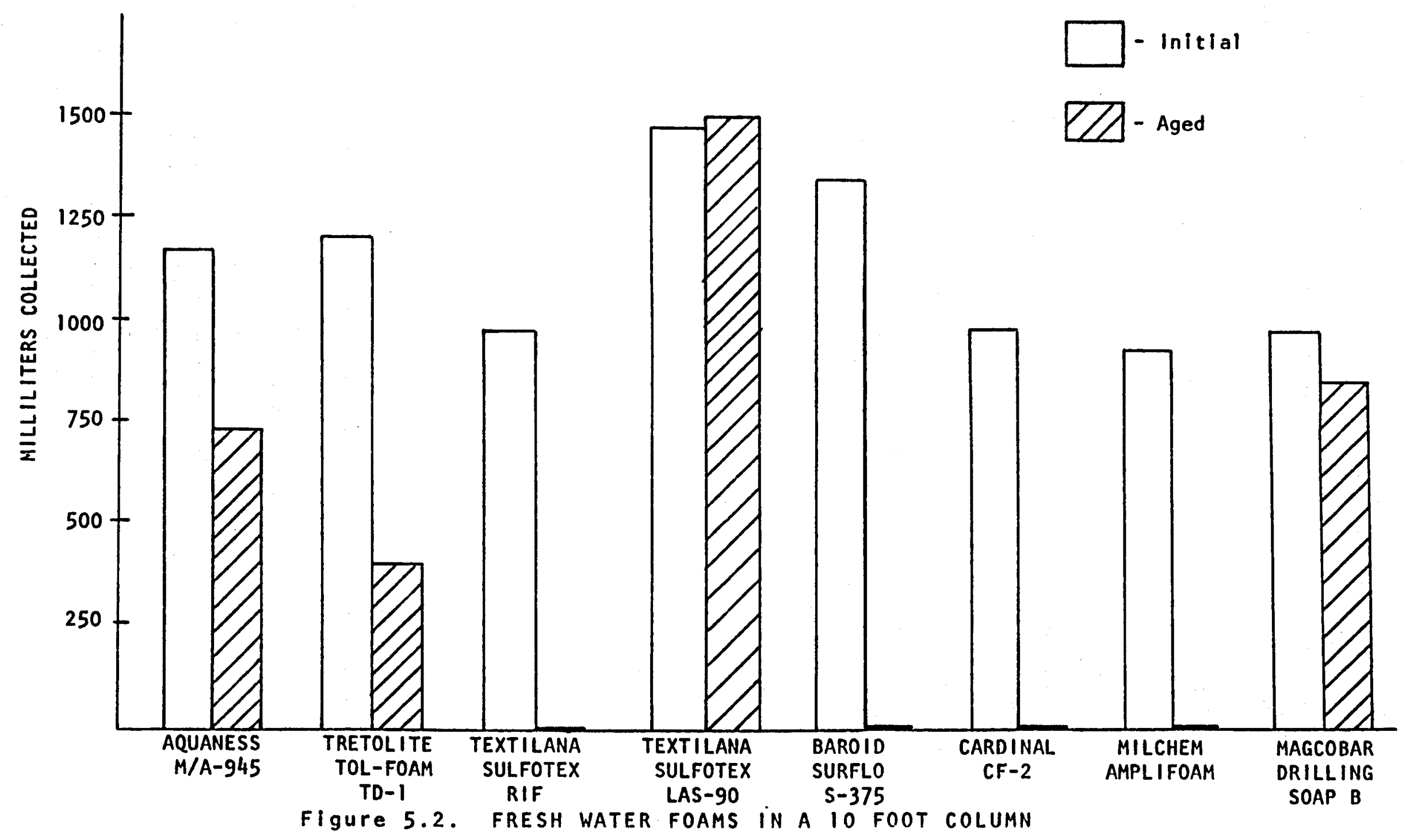

C.... 


\section{Liquid Carry-over by $0.75 \%$ Foamer in Ten Percent Sodium Chloride Solution}

When tested initially on the five foot column, seven of the foamers removed large amounts of salt water from the column. Textilana's Sulfotex LAS-90 removed about $20 \%$ less salt water than the-other foamers as shown in Figure 5.3. The volume of salt water removed by the other seven materials was within $6 \%$ of each other.

After aging 16 hours at $500^{\circ} \mathrm{F}-375$ psi, only Magcobar's Drilling Soap $B$ removed any salt water from the five foot column. Even here the amount of salt water removed was very low compared to that removed initially.

Similar results were obtained on the ten foot column as shown in Figure 5.4. Here again Textilana's Sulfotex LAS-90 removed the lowest amount of salt water initially. Tretolite's Tol-foam TD-1 removed a little more salt water than the Sulfotex LAS-90. The remaining materials removed about the same amount of salt water.

After exposure to $500^{\circ} \mathrm{F}$, again, only Magcobar's Drilling Soap $B$ removed any salt water. The amount removed on the ten foot column was even lower than that removed on the five foot column. 
Liquid Carry-over From A 5 Foot Column Containing $0.75 \%$

Foamer In A Ten Percent Sodium Chloride Solution

- initial
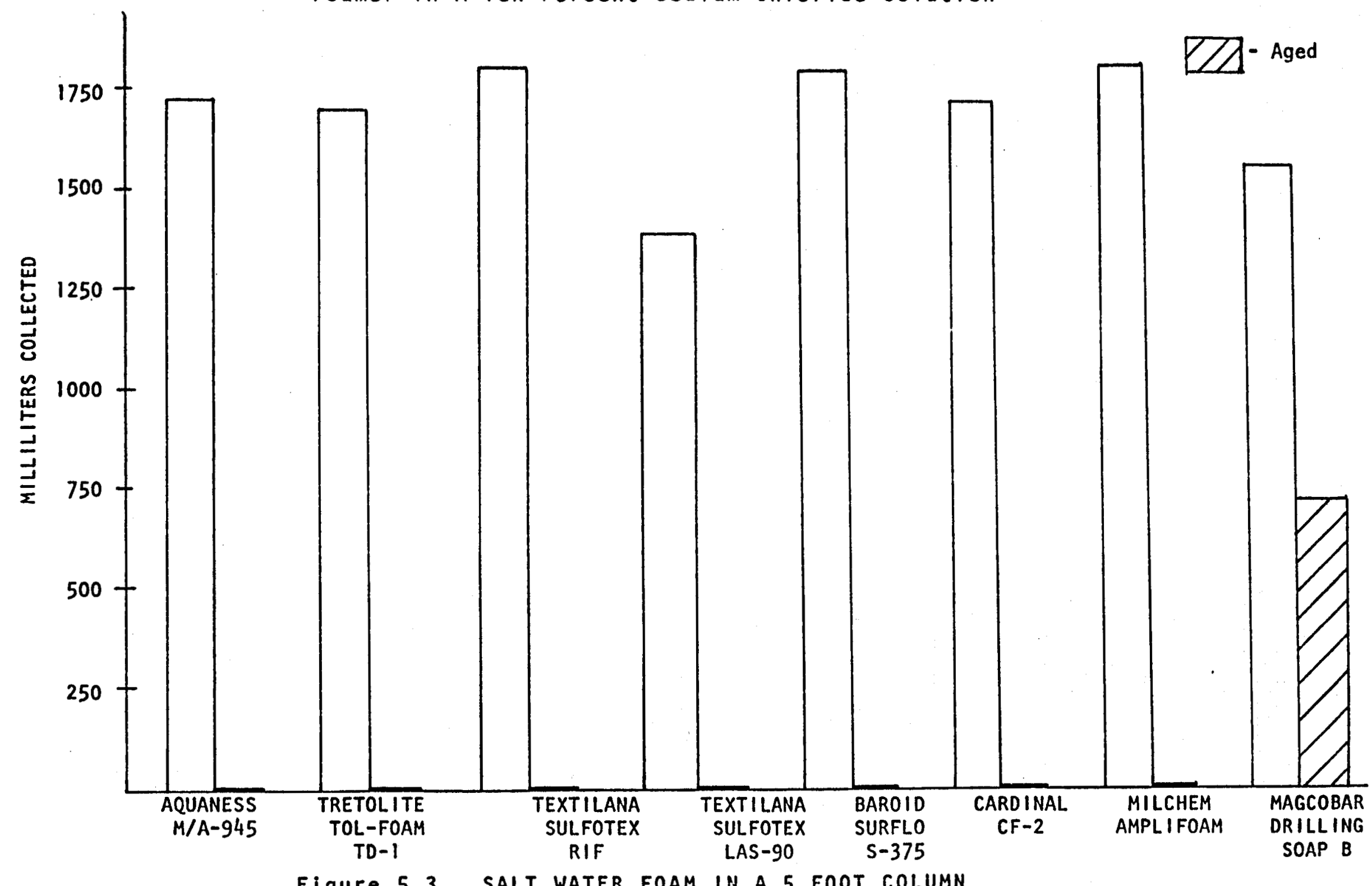

Figure 5.3. SALT WATER FOAM IN A 5 FOOT COLUMN

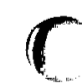


Liquid Carry-over From A 10 foot Column Containing

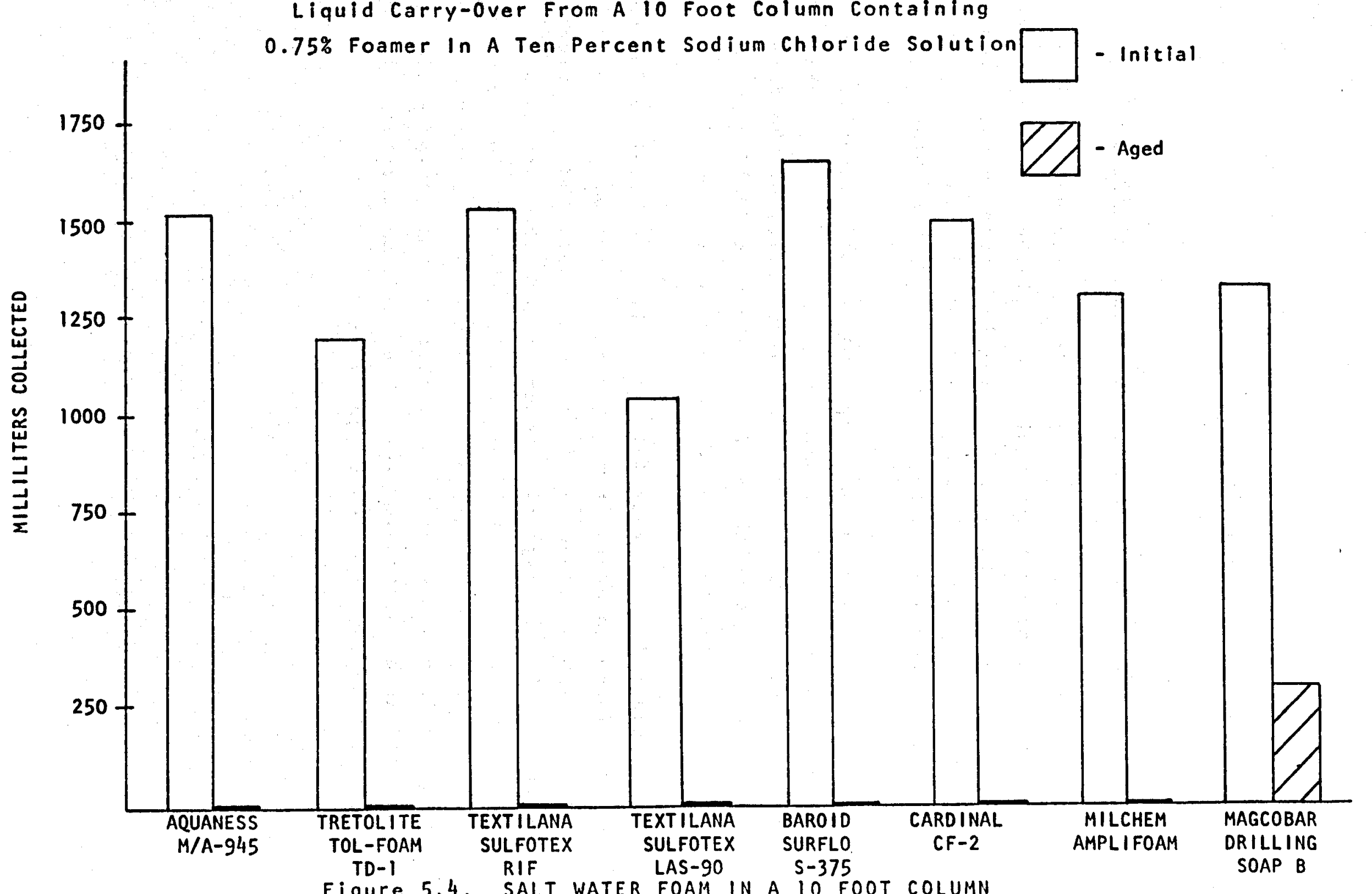




\section{Foams from $0.5 \%$ Foamer in Distilled Water}

Figure 5.5 shows that initially foam volumes of 6 to 7.5 times the volume of foamer solution could be generated by a high speed mixer. Foam quality, as indicated by the volume obtained from $100 \mathrm{ml}$ of foamer solution, increased when salt water was added and the solution was stirred at high speed.

Textilana's Sulfotex LAS-90 was the only material tested which foamed when stirred with the high speed mixer after aging 16 hours at $500^{\circ} \mathrm{F}-375$ psi. The quality of the foam formed after heating the sulfotex LAS -90 to $500^{\circ} \mathrm{F}$ was almost identical to the foam quality measured initially.

Table 5.1 shows that initially the time required for half of the liquid to drain from the foam generated with a high speed mixer was between $3-1 / 2$ and 5 minutes. No significant change in the drainage time occurred when the samples were restirred. Addition of $25 \mathrm{ml}$ of a $1 \%$ salt solution reduced the drainage time for all of the foamers except for Magcobar's Drilling Soap B. A further reduction in the drainage time occurred when the samples were restirred, except for Milchem's Amplifoam which increased slightly. 
Figure 5.5. Foam Volume Obtained From $100 \mathrm{ml}$ of $0.5 \%$ Foamer in Distilled liater

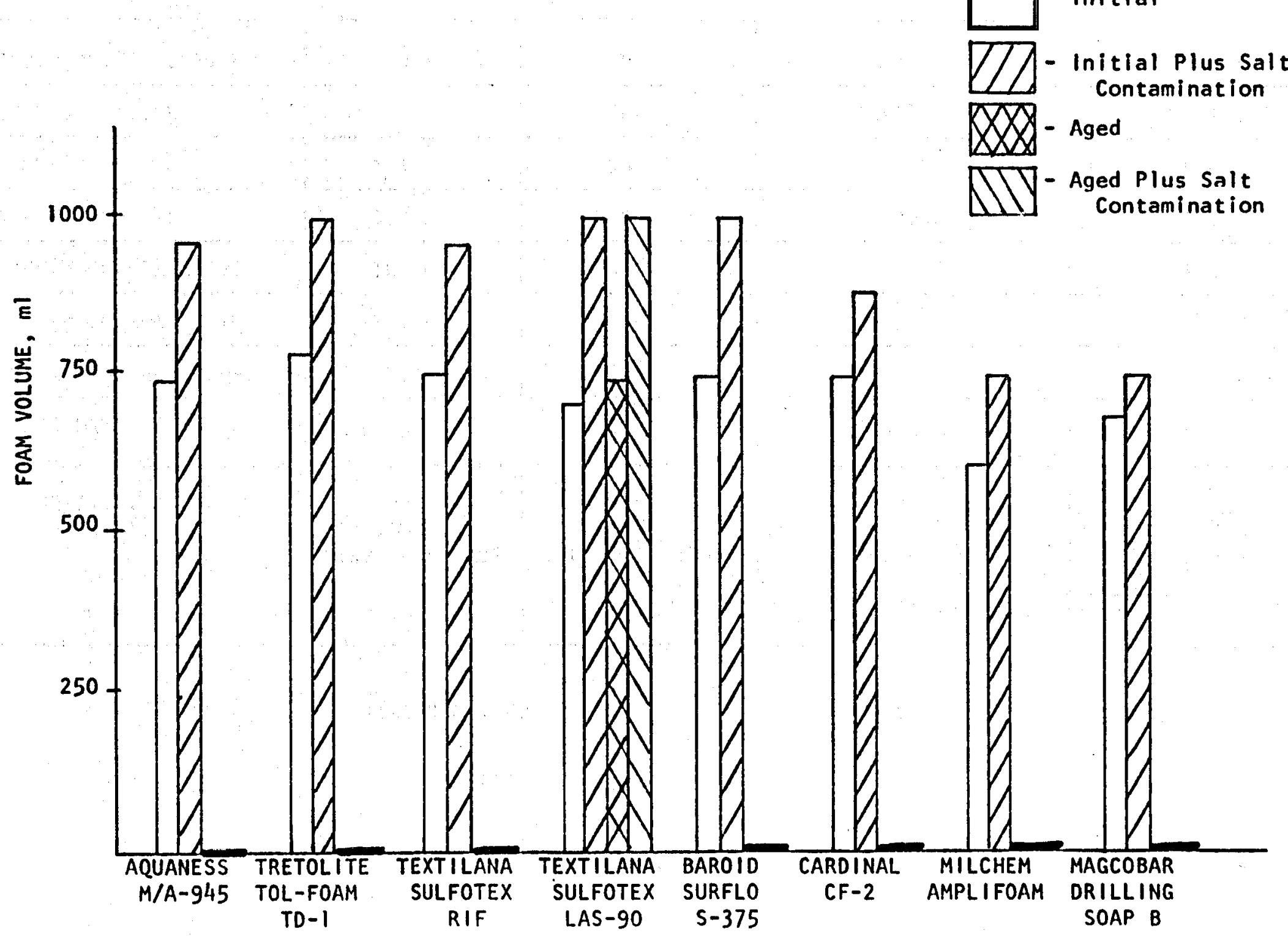


TABLE 5.1 .

\section{FOAMS GENERATED WITH A MIXER}

TIME REQUIRED FOR HALF OF THE LIQUIO TO ORAIN*

\begin{tabular}{|c|c|c|c|c|}
\hline $\begin{array}{c}\text { SAMPLE } \\
\text { IDENTIFICATION }\end{array}$ & $\begin{array}{l}\text { FIRST DRAINAGE } \\
\text { TIME, } \\
\text { SeC }\end{array}$ & $\begin{array}{c}\text { SECOND DRAINAGE } \\
\text { TIME, } \\
\text { SeC }\end{array}$ & $\begin{array}{c}\text { AFTER ADDITION OF } \\
\text { FIRST DRAINAGE } \\
\text { TIME. } \\
\text { SEC }\end{array}$ & $\begin{array}{c}\text { OF } 1 \% \text { SALT SOLUTION } \\
\text { SECOND DRAINAGE } \\
\text { TIME, } \\
\text { SEC }\end{array}$ \\
\hline AQUANESS $M / A-945$ & 247.7 & 265.1 & 210 & 172 \\
\hline TRETOLITE TOL-FOAM TD-1 & 229.2 & 234.5 & 203.5 & 196.5 \\
\hline TEXTILANA SULFOTEX RIF & 225.6 & 199.3 & 165 & 156.5 \\
\hline TEXTILANA SULFOTEX LAS-90 & 286.8 & 278.5 & 241.4 & 235.7 \\
\hline BAROIO SURFLO $\$ 375$ & 264.7 & 288.6 & 260.4 & 220.3 \\
\hline CARDINAL CF-2 & 291 & 299.5 & 234.4 & 225 \\
\hline MILCHEM AMPLIFOAM & 290.1 & 304 & 205 & 243.9 \\
\hline MAGCOBAR DRILLING SOAP B & 214.7 & 204.6 & 235 & 164.2 \\
\hline
\end{tabular}

*Initial Tests - $0.5 \%$ Foamer in Distilled Water 
Foam volumes generated when $100 \mathrm{ml}$ of $1.0 \%$ Foamer were stirred on the high speed mixer were only slightly higher than volumes obtained from $0.5 \%$ solutions as shown in Figure 5.6 . The effect of salt water additions and high temperature aging were almost identical as those previously observed on the $0.5 \%$ solutions. Again only Textilana's Sulfotex LAS-90 foamed after exposure to $500^{\circ} \mathrm{F}$ and the results obtained on the unheated sample were almost identical to those on the static aged sample.

Table 5.2 shows that the initial drainage times for the $1.0 \%$ solution of foamers was similar to those of the $0.5 \%$ solutions. Addition of salt water reduced the drainage time for all of the foamers tested at $1.0 \%$ concentration. No significant change in the drainage times occurred when the samples were restirred.

A comparison of the drainage times obtained on solutions of Textilana's Sulfotex LAS-90 is shown in Table 5.3. After exposure to $500^{\circ} \mathrm{F}$ only a slight reduction in the drainage time occurred. 
Figure 5.6. Foam Volume Obtained From $100 \mathrm{ml}$ of $1.0 \%$ Foamer in Distilled Water

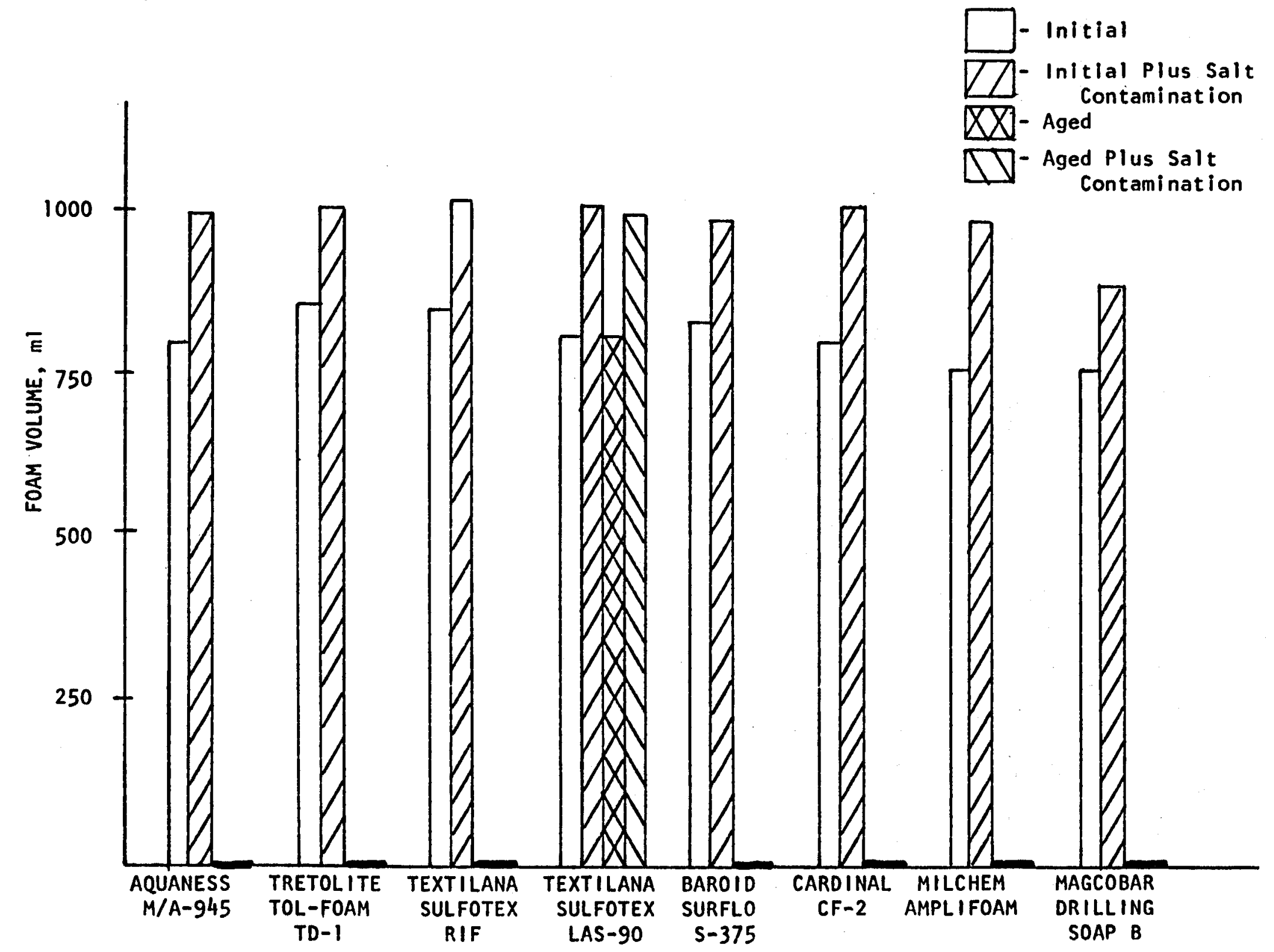


TABLE 5.2 .

FOAMS GENERATED WITH A MIXER

TIME REQUIRED FOR HALF OF THE LIQUID TO DRAIN*

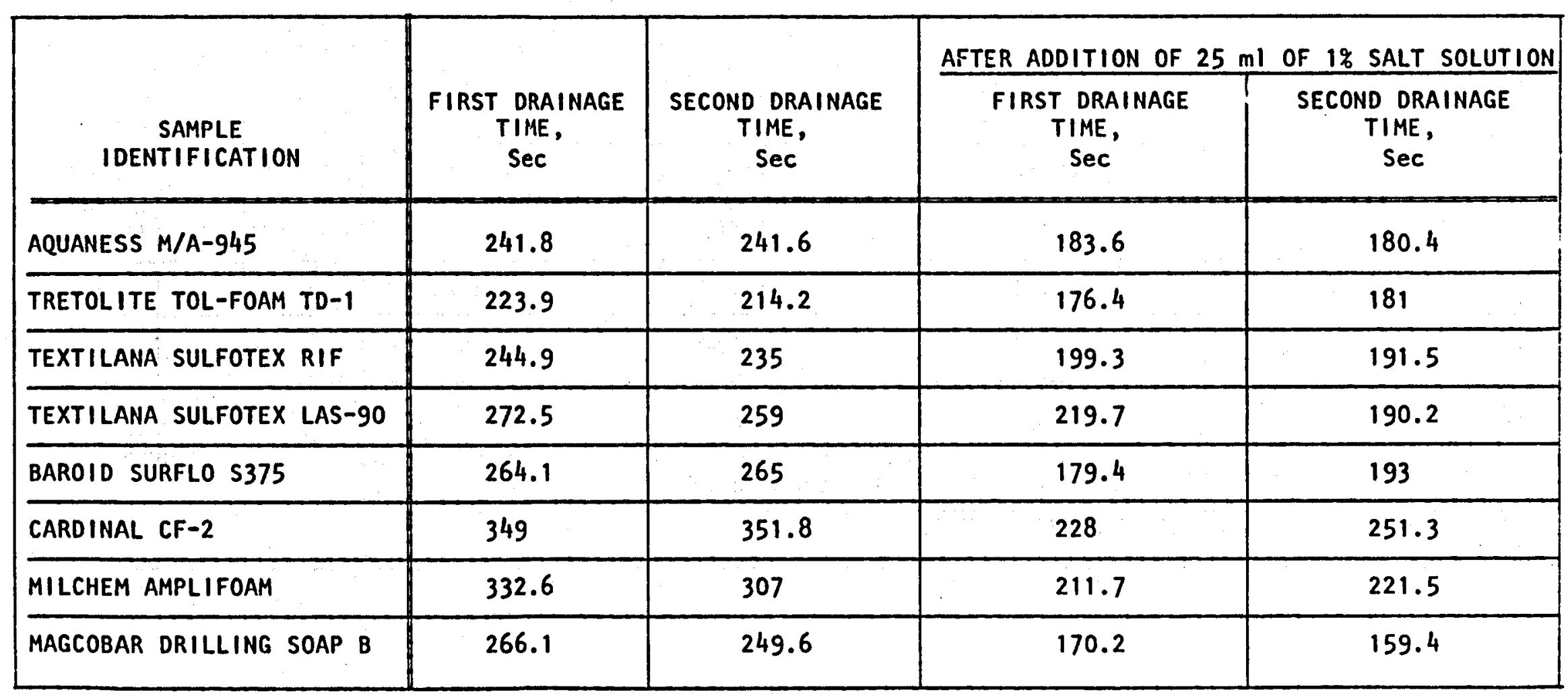

*Initial Tests - $1.0 \%$ Foamer in Distilled Water 
TABLE 5.3.

FOAMS GENERATED WITH A MIXER

DRAINAGE TIME FOR TEXTILANA'S SULFOTEX LAS-9O MEASURED INITIALLY

AND AFTER AGING AT $500^{\circ} \mathrm{F}-375$ PSI FOR 16 HOURS

\begin{tabular}{|c|c|c|c|c|c|}
\hline & & & & AFTER ADDITION OF & OF $1 \%$ SALT SOLUTION \\
\hline $\begin{array}{r}\text { SAM } \\
\text { IDENTIF }\end{array}$ & TION & $\begin{array}{c}\text { FIRST DRAINAGE } \\
\text { TIME, } \\
\text { Sec }\end{array}$ & $\begin{array}{c}\text { SECOND DRAINAGE } \\
\text { TIME, } \\
\text { SeC }\end{array}$ & $\begin{array}{c}\text { FIRST DRAINAGE } \\
\text { TIME, } \\
\text { Sec }\end{array}$ & $\begin{array}{c}\text { SECOND DRAINAGE } \\
\text { TIME, } \\
\text { SeC }\end{array}$ \\
\hline INITIAL & $0.5 \%$ & 286.8 & 278.5 & 241.4 & 235.7 \\
\hline & $1 \%$ & 272.5 & 259 & 219.7 & 190.2 \\
\hline AFTER AG ING & $0.5 \%$ & 231.5 & 247.3 & 210.9 & 201.3 \\
\hline $500^{\circ} \mathrm{F}-375 \mathrm{PSI}$ & $1 \%$ & 239.5 & 244.7 & 211.5 & 216.8 \\
\hline
\end{tabular}


Figures 5.7 and 5.8 show that all of the foamers which were tested lowered the surface tension of distilled water and a ten percent sodium chloride solution. A further reduction in the surface tension of distilled water solutions occurred when seven of the foamers were exposed to $500^{\circ} \mathrm{F}$ 375 psi for 16 hours. A slight increase in the surface tension of distilled watèr occurred after Cardinal's CF- 2 was heated to $500^{\circ} \mathrm{F}$.

Further reductions also occurred in the surface tension of the ten percent salt water treated with most of the foamers which were heated to $500^{\circ} \mathrm{F}$. No change in the surface tension occurred when the salt water was treated with Textilana's LAS-90 which was exposed to high temperature. A slight increase in the surface tension was again observed for the salt water which contained Cardinal's CF-2 after being heated to $500^{\circ} \mathrm{F}$.

\section{Corrosion Tests}

The corrosion rate of mild steel coupons exposed to water solutions of the foamers for 16 hours at $500^{\circ} \mathrm{F}-375 \mathrm{psi}$ is shown in Figure 5.9. The corrosion rate of distilled water and the ten percent sodium chloride solution is also shown for comparison. The only sample with a lower corrosion rate than the untreated waters was the sample treated with Textilana's Sulfotex LAS-90. Several of the saltwater solutions tested had corrosion rates greater than $50 \mathrm{mils}$ per year. Corrosion rates above this level are often considered excessive. Only 
Figure 5.7. 0.15\% FOAMER IN DISTILLED WATER

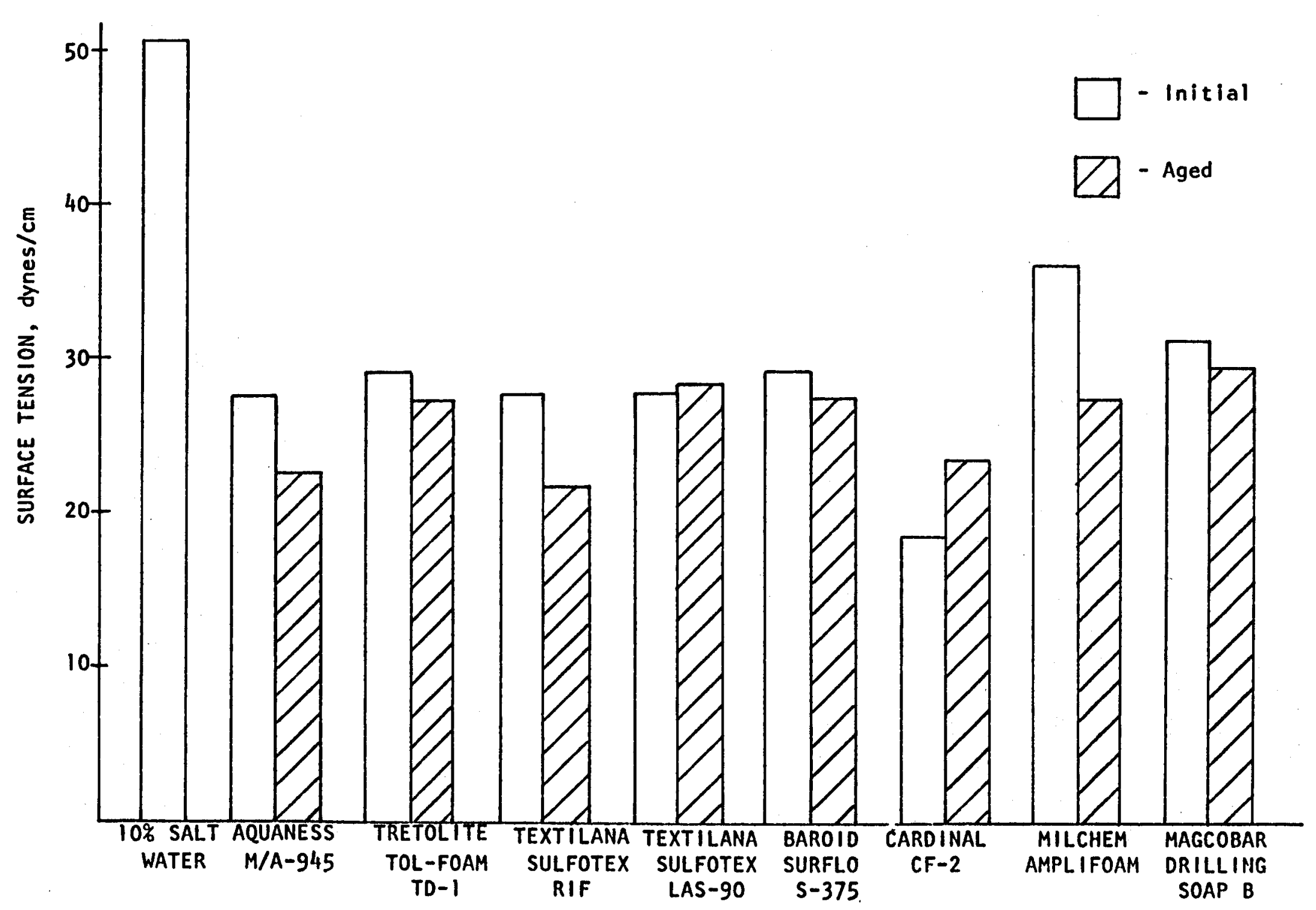




\section{SURFACE TENSION OF FOAMERS}

Figure 5.8. 0.75\% FOAMER IN A TEN PERCEHT SODILM CHLORIDE SOLUTION

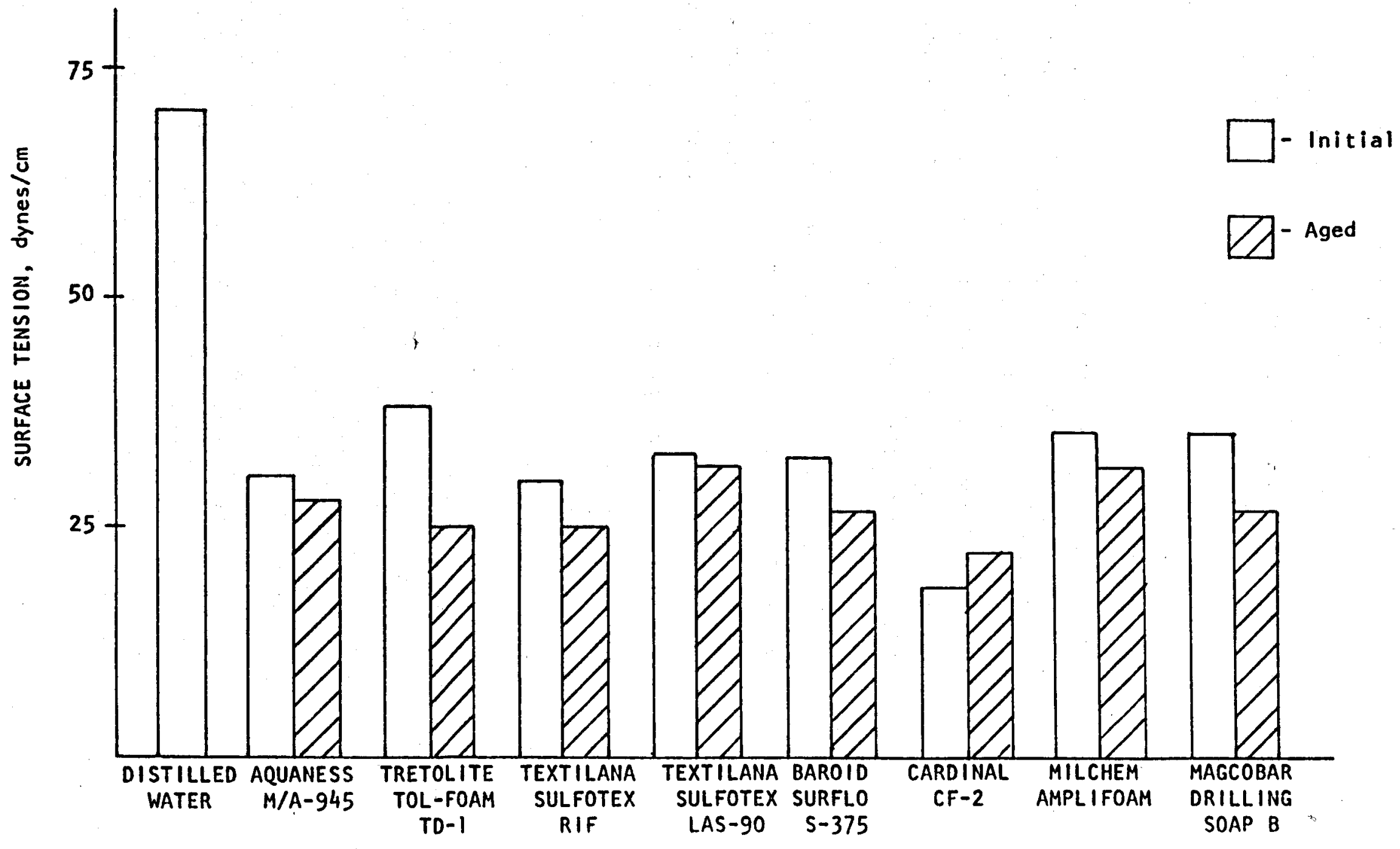


one of the materials tested, Milchem's Amplifoam, had a corrosion rate in excess of $50 \mathrm{mils}$ per year in fresh water.

pH

Addition of $0 . .5 \%$ of the foamers to distilled water increased the pH to $7.4-8.6$ as shown in Table 5.3. After aging 16 hours at $500^{\circ} \mathrm{F}$ - $375 \mathrm{psi}$, the pH was reduced to values ranging from 3 to 4 on samples containing AQUANESS N/A-945, Tretolite's Tol-Foam TD-1, Textilana's Sulfotex RIF, and Baroid's Surflo $\$ 375$.

Table 5.4 shows that the pH of the ten percent sodium chloride was nearly neutral or slightly alkaline when treated with $0.75 \%$ of the foamers. After aging at $500^{\circ} \mathrm{F}$ samples containing the same materials as mentioned earlier became acidic with pH's ranging from 2.9 to 3.1 . 
$C$

Figure 5.9 CORROSIOH RATES OF FOAMERS

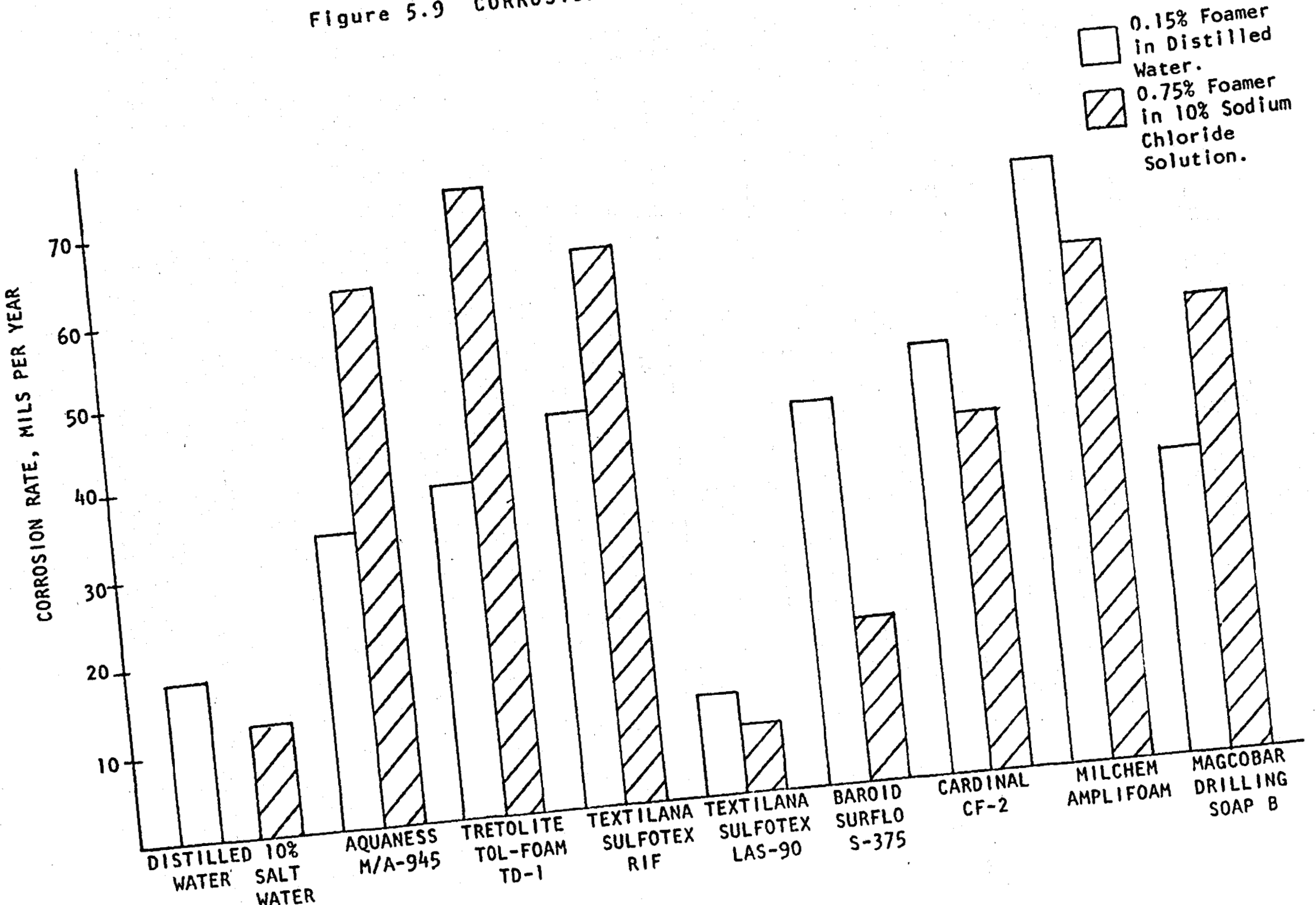


TABLE 5.4 .

PH OF $0.15 \%$ FOAMER IN DISTILLED WATER

\begin{tabular}{|l|c|c|}
\hline \multicolumn{1}{|c|}{$\begin{array}{c}\text { SAMPLE } \\
\text { IDENTIFICATION }\end{array}$} & $\begin{array}{c}\text { INITIAL } \\
\text { PH }\end{array}$ & $\begin{array}{c}\text { PH AFTER AGING } \\
16 \text { HOURS AT } \\
500^{\circ} \mathrm{F}-375 \text { PS i }\end{array}$ \\
\hline AQUANESS M/A-945 & 7.4 & 3.4 \\
\hline TRETOLITE TOL-FOAM TD-1 & 8.0 & 3.4 \\
\hline TEXTILANA SULFOTEX RIF & 7.5 & 3.5 \\
\hline TEXTILANA SULFOTEX LAS-90 & 8.5 & 8.1 \\
\hline BAROID SURFLO S375 & 7.6 & 3.1 \\
\hline CARDINAL CF-2 & 7.7 & 3.8 \\
\hline MILCHEM AMPLIFOAM & 8.6 & 8.3 \\
\hline MAGCOBAR DRILLING SOAP B & 7.8 & 7.1 \\
\hline
\end{tabular}


TABLE 5.5 .

PH OF $0.75 \%$ FOAMER IN A TEN PERCENT

SODIUM CHLORIDE SOLUTION

\begin{tabular}{|l|c|c|}
\hline $\begin{array}{c}\text { SAMPLE } \\
\text { IDENTIFICATION }\end{array}$ & $\begin{array}{c}\text { INITIAL } \\
\text { PH }\end{array}$ & $\begin{array}{c}\text { PH AFTER AGING } \\
16 \text { HOURS AT } \\
500^{\circ} \mathrm{F}-375 \text { PSi }\end{array}$ \\
\hline AQUANESS M/A-945 & 7.6 & 3.1 \\
\hline TKETOLITE TOL-FOAM TD-1 & 7.9 & 2.9 \\
\hline TEXTILANA SULFOTEX RIF & 6.7 & 2.9 \\
\hline TEXTILANA SULFOTEX LAS-90 & 8.2 & 7.5 \\
\hline BAROID SURFLO S375 & 6.9 & 3.0 \\
\hline CARDINAL CF-2 & 7.5 & 4.5 \\
\hline MILCHEM AMPLIFOAM & 8.4 & 8.3 \\
\hline MAGCOBAR DRILLING SOAP B & 6.8 & 7.4 \\
\hline
\end{tabular}




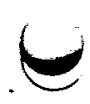




\section{SELECTION AND TESTING OF FOAMS}

Commercially available foamers used in drilling operations are normally proprietary blends. Mccutcheon's Detergents and Emulsifiers 1 ists over 2,000 materials and 49 classes of chemicals from over 150 suppliers in their 1978 North American Edition. Samples of foamers currently being used were requested from many of the larger manufacturers and suppliers. Table 6.1 contains a list of 36 samples, submitted by 15 suppliers. These materials were received during the course of this investigation.

TABLE 6.1

ALCO

Trenamine $A L-19$

AQUANESS CHEMICAL COMPANY

M/A 877

$M / A 941$

M/A 945

BRINADO

Brinefoam

CARDINAL COMPANIES

$$
\text { CF }-2
$$

DAVE NAGEL

DN- 100

$D N-200$

\section{DRESSER MAGCOBAR}

Drilling Soap $A$

Drilling Soap B

Drilling Soap $C$

Unmarked Sample

DUPONT

ZonyI FSA

Zonyl FSB

Zonyl FSC

Zonyl FSJ

Zonyl FSN

Zonyl FSP
FAR-BEST

Thermofoam BW-D

MILCHEM

Ampli-Foam

Gel-Air

NL BAROID PETROLEUM SERVICES

Surflo S 362

Surflo S 375

Surflo 5378

Surflo S 390

SELECT CHEMICAL COMPANY

SC 403

SC 404

SOONER CHEMICAL COMPANY

CI 800

MF 250

TEXTILIANA

Sulfotex AOS

Sulfotex LAS-90

Sulfotex PAI

Sulfotex RIF

Sulfotex SAL

TRETOLITE DIVISION

TO1-Foam TD-1

Tol-Foam TD-12 
Eight of the materials in Table 6.1 were selected for testing. Selection was based on availability of a sufficient amount of sample to complete all tests and timely reception of the samples. The number of samples which could be tested was limited by time restraints to eight samples. The following materials were selected.

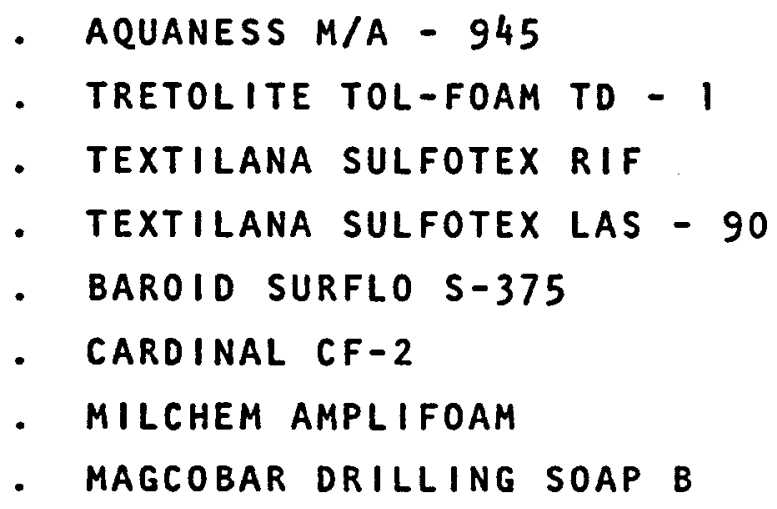

The foamers were tested initially and after exposing water solutions of the materials to $500^{\circ} \mathrm{F}$ at an applied nitrogen pressure of 375 psi for 16 hours. Foams were generated by injecting a solution of the foamer into an air stream in a column and by stirring a solution of the foamer with a high speed mixer. Other tests included the corrosion rate of mild steel, $\mathrm{pH}$, and surface tension measurements on water solutions or $10 \%$ sodium chloride solutions of the foamers. Detailed descriptions of these tests follows.

\section{Column Testing of Foamers}

This test is a modification of an API procedure for testing foaming agents for use in mist drilling? The column test is set up to simulate well design and drilling practices, as well as to provide a procedure which can be

1. API RP-46 
easily reproduced in most laboratories.

Basically, the test involves injection of air and a foaming agent solution into the bottom of a model well column. The air and liquid mix produces foam. The foam rises to the top of the column and exits through an outlet port and into a tared container. The material collected is weighed and the weight converted to volume. Since air and liquid flow rates are kept constant throughout each test, the various amounts of foam collected are used to rate each of the products tested.

Equipment

The individual components of the column system are listed below (see Figure 6.1).

1. Pump: A positive displacement pump is used for continuous injection of standard solutions of the foaming agents into the column. A back pressure valve is included downstream in the discharge line to aid in maintaining a constant flow rate.

2. Reservoir: A 4 liter reservoir with a magnetic stirrer is attached to the intake line of the pump.

3. Column: A 10 foot column made of clear lucite is used in the API testing procedure (see figure 6.1). A 5 foot column is used in a modification of the API procedure. Other than height, the 5 foot column is identical in all other dimensions to the 10 foot column. Removeable plugs are located at the top and bottom oi each column.

4. Air-liguid inlet tube: A $3 / 4$ inch diameter stainless steel tube is centered inside the column and emerges through a concentric opening in the top plug. A " $T$ " type conncetion at the top provides inlets for air and the standard foam solutions. 


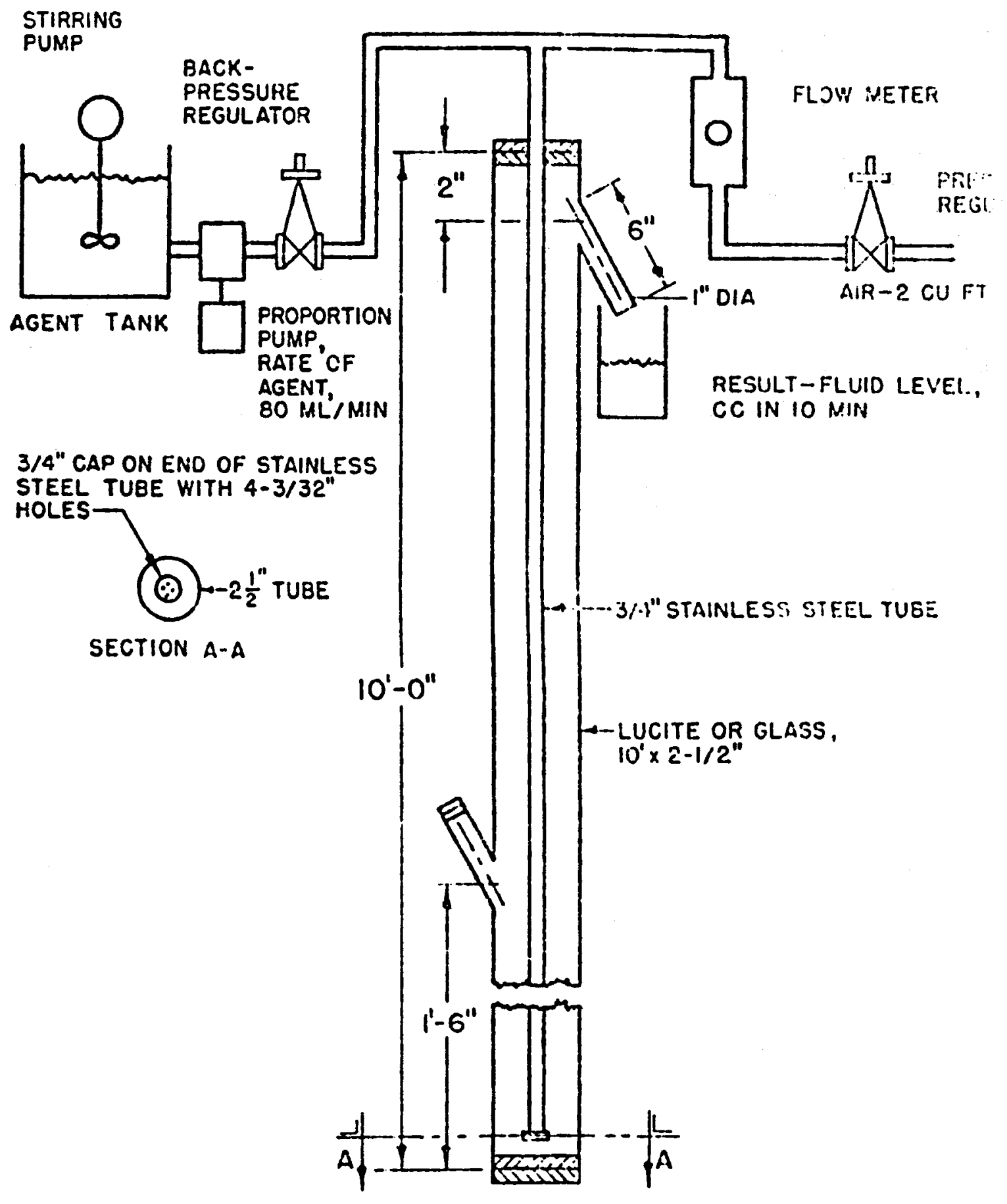

Figure 6.1. Laboratory Apparatus For Testing Foam Agents 


\section{Flow meter: A florator is used to monitor air flow. An air compressor and regulator provide constant air pressure.}

Tests

The following standard solutions are prepared for testing in the column tests:

\begin{tabular}{lcc} 
& $\begin{array}{c}\text { Fresh } \\
\text { Water }\end{array}$ & $\begin{array}{c}\text { Salt } \\
\text { Water }\end{array}$ \\
\hline Distilled Water, ml & 13,000 & 13,000 \\
Sodium Chloride, gm & & 1,368 \\
Foaming Agent, oby volume & 0.15 & 0.75 \\
Stirring time, min & 5 & 5
\end{tabular}

The solutions are tested immediately after preparation. Each standard solution is tested four times; twice on the $5 \mathrm{ft}$ column and twice on the $10 \mathrm{ft}$ column. The test procedure is as follows:

1. Add $1 \mathrm{gm}$ of 140-mesh silica flour to the bottom of the dry column to simulate the foam breaking effects of drilled solids.

2. Add 1 litter of the standard test solution through the inlet and into the bottom of the column. Add 4 liters of this solution to the reservoir.

3. The pump output is adjusted to $80 \mathrm{ml} / \mathrm{min}$.

4. Air flow is adjusted to 2 standard cubic feet per minute through a check line while the inlet valve to the column is shut. The valve to the column is then opened at the same time a timer is started. 
5. Test solution flow into the column is started as soon as foam from the initial solution in the bottom of the column reaches the top exit port of the column.

6. Foam overflow at the top of the column is collected for 10 minutes.

7. The foam is collected in a tared container and weighed. This allows the volume of the liquid to be calculated.

8. Steps 2-8 are repeated on both the $5 \mathrm{ft}$ and $10 \mathrm{ft}$ columns.

9. After each run, the column is thoroughly flushed with water. Before a new standard solution, is introduced into the reservoir. the entire system is flushed with water to avoid contamination from the previous sample.

Foam Screening Test Using a High Speed Mixer to Generate The Foam

This test is a modification of a test prcedure that was developed by Chevron. The procedure used in this investigation is as follows:

1. Place $100 \mathrm{ml}$ of distilled water into a $1,000 \mathrm{ml}$ beaker.

2. Add foamer $(1 / 2 \mathrm{ml}$ or $1 \mathrm{ml})$.

3. Mix in beaker with a Hamilton Beach mixer for 30 seconds.

4. Measure foam volume by reading the graduated scale on beaker and record.

5. Measure the time required for $50 \mathrm{ml}$ of liquid to drain from the foam after the mixer is shut off and record as the first drainage time. 
6. Refoam by mixing on the Hamilton Beach mixer for 30 seconds and obtain a second reading of foam height.

7. Measure the time required for $50 \mathrm{ml}$ of liquid to drain from the foam after the mixer is shut off and record as the second drainage time.

8. Add $25 \mathrm{ml}$ of $1 \%$ by weight sodium chloride solution to the foam from $\# 6$.

9. Repeat Steps 3,4, 5, and above.

Surface Tension

Standard solutions of foaming agents were prepared at the same concentrations used in the column testing. Surface tensions of the various standard solutions were measured using the Graham Tensiometer, shown in Figure 6.2. The method outlined below was used to calculate the surface tension.

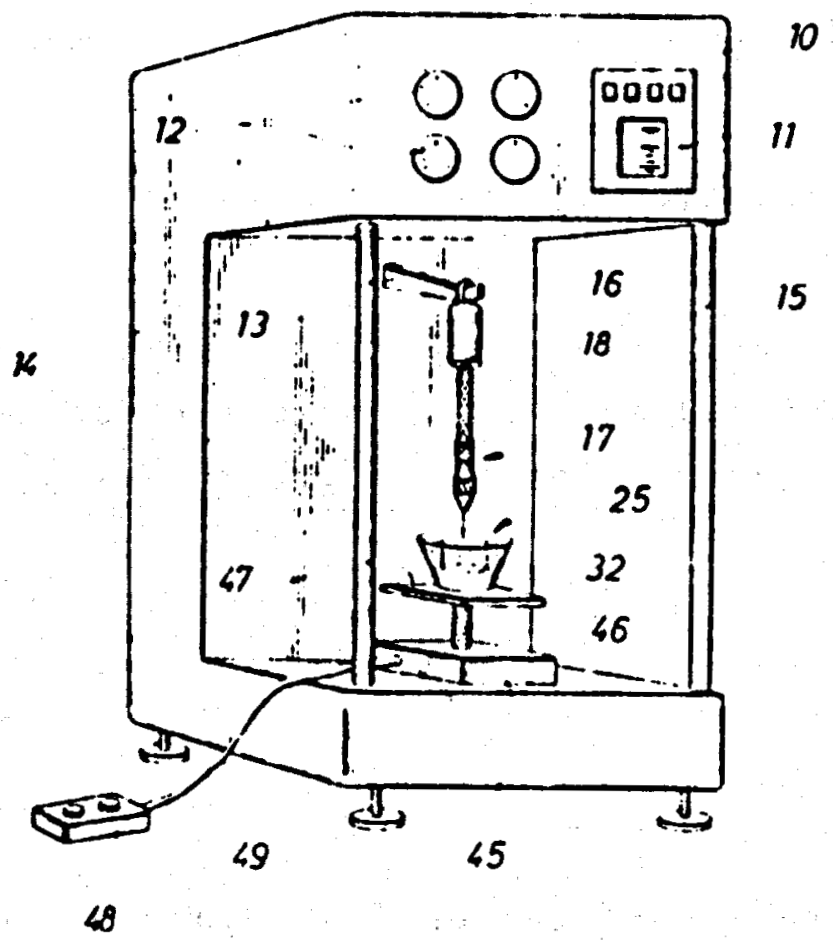

Figure 6.2. Graham Tensiometer Mounted in a Metler Balance (Drawing from U.S. Patent \#3,780,569) 
Procedure for Using the Graham Tensiometer

This method measures the upward force exerted on a small wire ring as the ring is pulled through a liquid to air interface. The upward force is opposed by the downward force exerted on the ring by the elastic, membrane-like interface of the solution (see Figure 6.3).

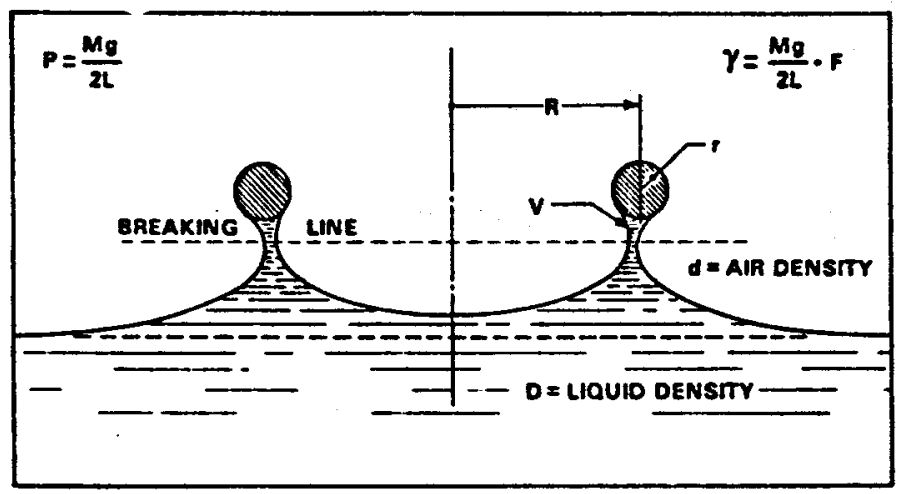

Figure 6.3. Condition of Surface Film at Breaking Point

The maximum resisting force, $P$, of the interface prior to rupture is defined as the apparent surface tension of the solution. The equation for calculating $P$ is given below:

$$
P=\frac{M g}{2 L} \cdot \cdot \cdot \cdot \cdot \cdot \cdot \cdot \cdot
$$

where

$$
\begin{aligned}
& P=\text { apparent surface tension, dynes per } \mathrm{cm} \\
& M=\text { mass, grams } \\
& L=\text { mean circumference of ring } \\
& g=\text { acceleration of gravity }=979.895 \mathrm{~cm} / \mathrm{sec}^{2}
\end{aligned}
$$

96 
Several physical occurrences arise between the ring and the surface film at the point of rupture (see Figure 6.3).

1. Two surface films balance the upward pull, one interior to the ring and one exterior to the ring.

2. The distance from the center of the ring to the breaking point is less than the mean radius of the ring.

3. A small volume of liquid clings to the ring and complicates the force balance calculation.

The occurrences necessitate an addition of a correction factor in the circulation. Zuidema and Waters have published a formula which gives a correction factor, F, accounting for these phenomena. Multiplication of the apparent tension by $F$ gives the true value of surface tension, $\gamma$ :

$$
Y=(P)(F) \cdot \cdot \cdot \cdot \cdot \cdot \cdot
$$

\section{Converting the Mettler Balance to a Tensiometer}

Conversion of the Metter Balance to a tensiometer using the Graham Tensiometer is accomplished as follows:
a. Remove pan from pan hook.
b. Remove pan brake from socket.
c. Insert stem of platinum - irridium ring in pin vise section of tensiometer assembly. Lock pin vise.


d. Hang tensiometer assembly from pan hook.

e. Place movable platform assembly on balance floor beneath Graham Tensiometer.

2. Measurement of Surface Tension

To measure surface tension:

a. Half fill a suitable glass container with the test solution.

b. With the solution in place on the platform, raise the platform until the ring is about

$2 \mathrm{~mm}$. beneath the test solution surface.

c. Determine the apparent weight of the assembly (with ring submerged) using standard analytical balance procedure. Record this weight, $W_{1}$.

d. With balance in "partial release" position, slowly lower the platform so that the ring slowly ascends through interface. When movement of the optical scale indicates that an "on scale" reading may be obtained, the balance is put in "full release" position. If further lowering of the platform produces an off-scale reading before rupture of the interface, the balance is returned to the parilal release position and the weight increased by $0.1 \mathrm{gm}$. Continuing carefully in this manner, the apparent "weight" associated with interfacial rupture is obtained. Record this we ight, $W_{2}$.

Having determined $M=W_{2}-W_{1}$, the apparent surface tension, $P$, is calculated from Equation (1). To determine the correction factor, $F$. enter Figure 6.4 with the value $P /(D-d)$. The true value of surface tension is, then: 


$$
Y=(F)(P)
$$

e. Cleaning: Accuracy of surface tension measurements depends strongly on the cleanliness of the platinum ring surface area. Consequently, the ring must be thoroughly cleaned before and after each test. Clean the platinum ring by rinsing it in methyl ethyl ketone. Then heat in the oxidizing portion of a gas flame until a "cherry-red" color appears. Flame only that portion of the ring which will be immersed in the liquid under test.

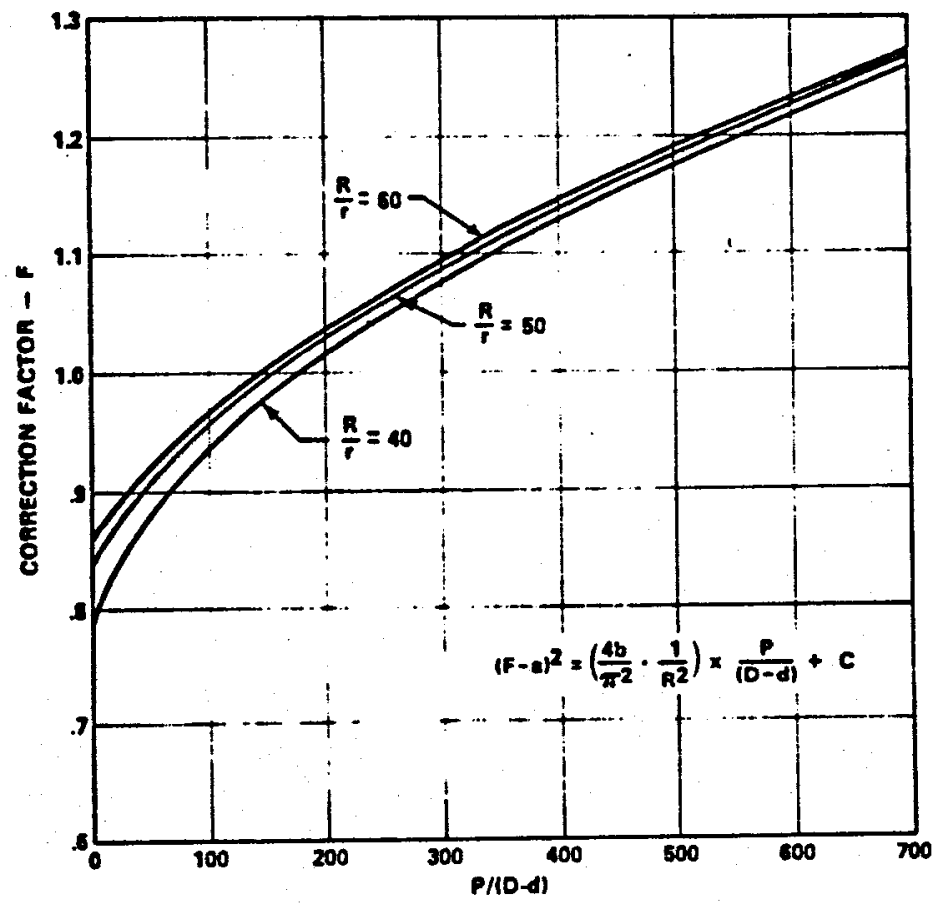

Figure 6.4. Correction Factor for Surface and Interfacial Tension by Ring Method ( $6 \mathrm{~cm} \mathrm{Ring}$ ) 
U 


\section{RECOMMENDED PROGRAM}

Currently, foams used to drill geothermal wells degrade when exposed to high temperatures. Many expensive fishing jobs are caused by the corrosive effects of acidic products formed when the foaming agents degrade. Rapid corrosion also occurs if acidic formation. fluids enter the wellbore causing a reduction in the $\mathrm{pH}$ of the water phase of the foam. The high costs for using foams is also influenced by the fact that the foaming agent is injected continually at the stand pipe and discarded at the blooie line.

A program to develop improved foams should consist of the following elements:

1. Design, manufacture, and test laboratory equipment for testing foams at $700^{\circ} \mathrm{F}$.

2. Design, manufacture, and test equipment to recover the foaming agent and remove solids in order to recycle the foamer.

3. Develop improved foams for use at $550^{\circ} \mathrm{F}$.

4. Develop improved foams for use at $700^{\circ} \mathrm{F}$.

Table 7.1 contains a proposed budget to support this program. 
TABLE 7.1

$\frac{\text { PROPOSED EXPENDITURES FOR FOAMS }}{\text { (Thousand DOllarS) }}$

FY-78 FY-79 FY-80 FY-81 FY-82 FY-83 FY-84 FY-85 TOTAL

State-of-the-Art Study Program Formulated

100

100

Equipment

Laboratory
Field

175

150

$50 \quad 125$

125

100

325

Developing Improved foams

Phase $1-550^{\circ} \mathrm{F}$

Phase $11-700^{\circ} \mathrm{F}$

\begin{tabular}{|c|c|c|c|c|c|c|c|c|}
\hline & & 100 & 200 & $\begin{array}{r}125 \\
75 \\
\end{array}$ & $\begin{array}{r}75 \\
200 \\
\end{array}$ & 200 & 100 & $\begin{array}{r}500 \\
575 \\
\end{array}$ \\
\hline 100 & 175 & 250 & 250 & 325 & 400 & 300 & 100 & 1900 \\
\hline
\end{tabular}




\section{Laboratory Equipment}

In order to develop foams capable of functioning under geothermal conditions, equipment suitable fcr testing foamers must be developed. A laboratory instrument capable of generating foam, hating the foam to temperatures up to $700^{\circ} \mathrm{F}$, measuring the rheological characteristics at the elevated temperature, cooling the foam to near ambient temperature, and discharging the foam at atmospheric pressure must be developed. A 2-year program to design and build this equipment should begin during FY-1979.

The laboratory equipment should be designed to simulate the temperature and pressure experienced by foam in the drilling operation. At least two basic approaches should be considered in order to simulate the foam cycle. One approach would be to inject foamer into an air stream at approximately 300 psi and rapidly heat the foam to elevated temperatures as the foam moves through the system. Pressuredrop measurements could then be obtained at the elevated temperature.

The foam would then have to be cooled rapidly and then discharged at atmospheric pressure. Temperatures and pressures could be simulated in this system, but residence time would be very short compared to actual residence time in the hole. This system would be similar to a flow loop used to test drilling muds .

Anothcr approach which should be considered would be to aggitate the foamer in a closed vessel to simulate foam formation and movement in the drilling process. Pressure and temperature could be closely controlled and monitored in this system. Residence time and the degree of aggitation could also be regulated in order to simulate the shear history experienced by the foam. 
Either of the above systems could be used to simulate pressure and temperature experienced by foams, but the second system has the advantage of being able to simulate residence time of foams

\section{Field Equipment}

Equipment for deaerating the foam, removing-the solids from foams and recycling the foaming agents must also be developed. This program should begin during FY-1981. The design of this equipment should be complete by FY-1982. Equipment fabrication can be accomplished late in FY-1983. Field test should be scheduled for early in FY-1984.

Foam deaerating equipment must be capable of handling the total flow from the well. Gas flow could range from 350 to 500 cubic feet per minute. Techniques which should be considered for deaerating the foam are sonic, vacuum, electrical, chemical, and thermal. Chemical additions to foams might cause problems with reuse of the foams. Any material used to defoam the system would probably hinder the reformation of a foam. Use of thermal methods to break foams could also cause irreversible changes in the chemical compositon of the foamer. A vacuum technique might be suitable for separating the air from the liquid, but a major consideration must be the size of the equipment and the cost to operate this equipment. An electrical spark might cause the liquid to separate from the air without damaging the chemical foamer. High frequency sound has been used to defoam liquids which contained a small amount of entrained gas. Here again, equipment size, initial cost, and operating cost will be major considerations 
Developing Improved Foams

The remainder of the program consists of developing foamers stable at $550^{\circ} \mathrm{F}$ and $700^{\circ} \mathrm{F}$. These two target temperatures are represented as separate phases in the project to develop imfroved foams. Laboratory equipment developed earlier in the program should be used to test candidate materials.

\section{Phase $1-550^{\circ} \mathrm{F}$}

In FY-1980 a study should be initiated to investigate foam systems which will be stable at $550^{\circ} \mathrm{F}$. The laboratory test portion of this study should be complete by the middle of FY-1981. Field tests should be scheduled and conducted in FY-1982. This project should be complete by late in FY- 1983

\section{Phase $11-700^{\circ} \mathrm{F}$}

In FY-1982, work should begin on developing foams stable at $700^{\circ} \mathrm{F}$. Laboratory tests should be completed by Fy-1983. Foam systems developed in this study should be field tested during FY-1984. All work on developing improved foams should be completed by FY-1985.

Table 7.2 contains the Milestones for this program. 


\section{Laboratory Equipment}

In order to develop foams capable of functioning under geothermal conditions, equipment suitable for testing foamers must be developed. A single pass laboratory instrument capable of generating foam, heating the foam to temperatures up to $700^{\circ} \mathrm{F}$, measuring the rheological characteristics at the elevated temperature, cooling the foam to near ambient temperature, and discharging the foam at atmospheric pressure must be developed. A 2-year program to design and build this equipment should begin during FY-1979.

\section{Field Equipment}

Equipment for deaerating the foam, removing the solids from foams and recycling the foaming agents must also be developed. This program should begin during FY-1981. The design of this equipment should be complete by FY-1982. Equipment fabrication can be accomplished late in FY-1983. Field test should be scheduled for early in FY -1984 .

\section{Developing Improved Foams}

The remainder of the program consists of developing foamers stable at $550^{\circ} \mathrm{F}$ and $700^{\circ} \mathrm{F}$. These two target temperatures are represented as separate phases in the project to develop improved foams. Laboratory equipment 
developed earlier in the program should be used to test candidate materials.

\section{Phase $1-550^{\circ} \mathrm{F}$}

In FY-1980 a study should be initiated to investigate foam systems which will be stable at $550^{\circ} \mathrm{F}$. The laboratory test portion of this study should be complete by-the middle of FY-1981. Field tests should be scheduled and conducted in FY-1982. This project should be complete by late in FY-1983.

\section{Phase $11-700^{\circ} \mathrm{F}$}

In FY-1982 work should begin on developing foams stable at $700^{\circ} \mathrm{F}$. Laboratory tests should be completed by FY-1983. Foam systems developed in this study should be field tested during FY-1984. All work on developing improved foams should be completed by FY-1985.

Table 7.2 contains the Milestones for this program. 
MILESTONES

$F Y-78 \quad \underline{F Y-79} \quad \underline{F Y-80} \quad \underline{F Y-81} \quad F Y-82 \quad F Y-83 \quad \underline{F Y-84} \quad F Y-85$

State-of-the-Art Study Program Formulated

\section{Equipment \\ Laboratory \\ Field}
Developing Improved Foams
Phase $1-550^{\circ} \mathrm{F}$
Phase $11-700^{\circ} \mathrm{F}$

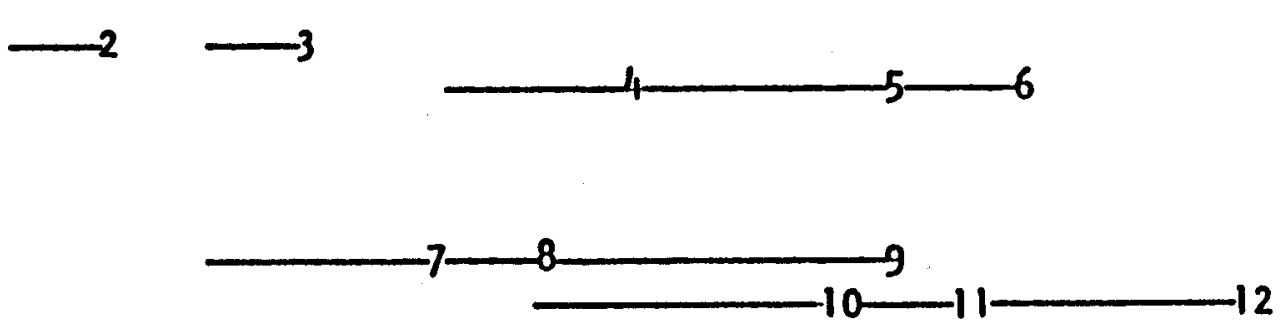

1. State-of-the-Art Study Completed. Program Formulated. 7. Laboratory Tests of $550^{\circ} \mathrm{F}$ Foam Complete.

2. Design Complete.

8. Field Tests of $550^{\circ} \mathrm{F}$ Foam.

3. Laboratory Equipment Completed.

4. Design of Field Equipment Complete.

9. $550^{\circ} \mathrm{F}$ Foam Work Complete.

5. Field Equlpment Fabricated.

6. Fleld Tests of Foam Handling Equipment.

10. Laboratory Tests of $700^{\circ} \mathrm{F}$ Foam Complete.

11. Field Tests of $700^{\circ} \mathrm{F}$ Foam.

12. $700^{\circ} \mathrm{F}$ Foam Work Complete. 
APPENDIX.A.

A complete analysis was made of the iterative equation presented under "The Effect of Foam."

$$
\begin{aligned}
& h=\frac{1}{D}\left[p+\frac{n p}{100-n} \ln \left(\frac{p+p}{d}\right)\right] \\
& h=\text { depth, ft } \\
& \text { D = hydrostatic pressure, psi, of a column } \\
& \text { of fluid one foot high with no air in it } \\
& p \text { - pressure in atmospheres at depth } h \text { due } \\
& \text { due to mud column only } \\
& p=\text { back pressure at wellhead, atmospheres } \\
& \begin{aligned}
& \frac{n}{100}=\text { fraction by volume of gas in mud at wellhead } \\
& \text { at back pressure } p
\end{aligned}
\end{aligned}
$$

Tables 1 - 7 are respentative samples of analysis from which figures 7,8 , and $g$ in the text were developed.

In the Tables, "pressure" is gauge pressure, "Density" is average density to the surface, and "q" is the percent fluid in the foam at that depth. 


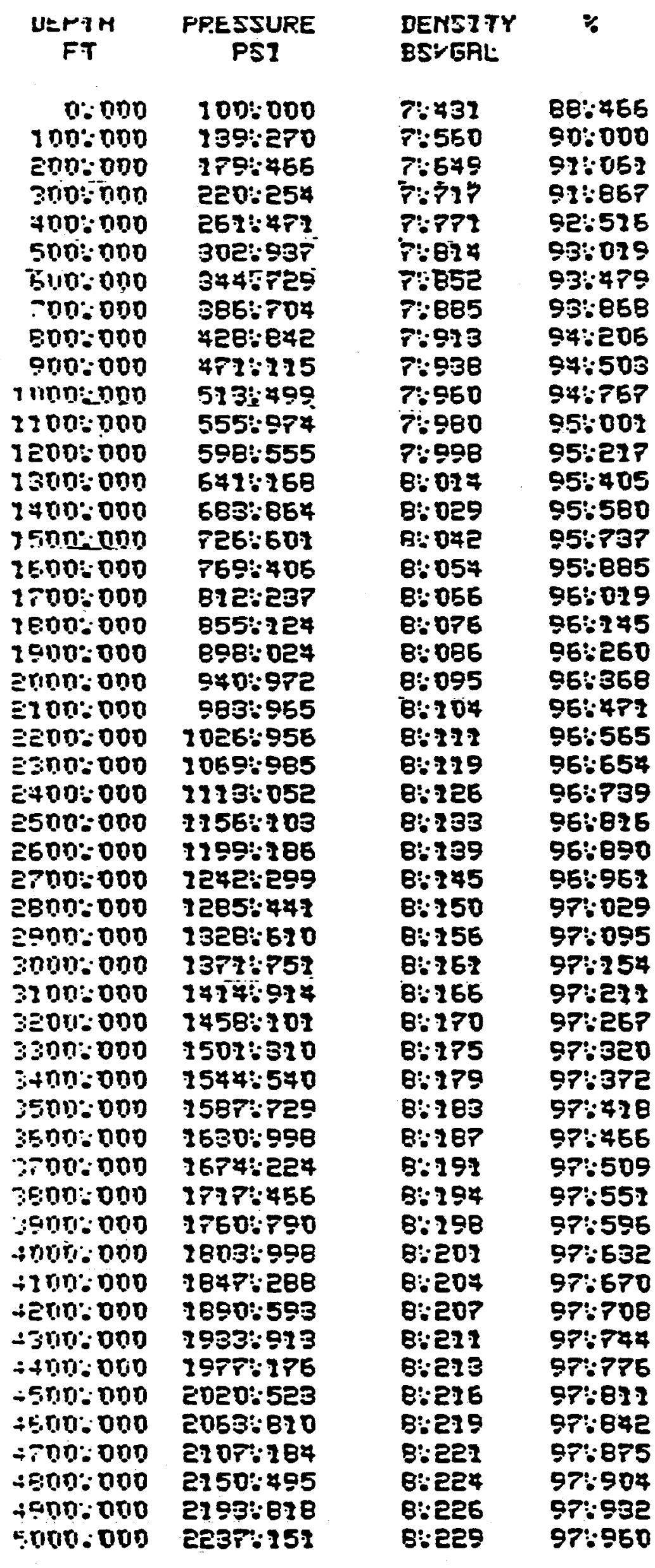

Uncut Hud Wt. 8.4 ppg Ratio Air:fluid at "O" gauge 10:1 


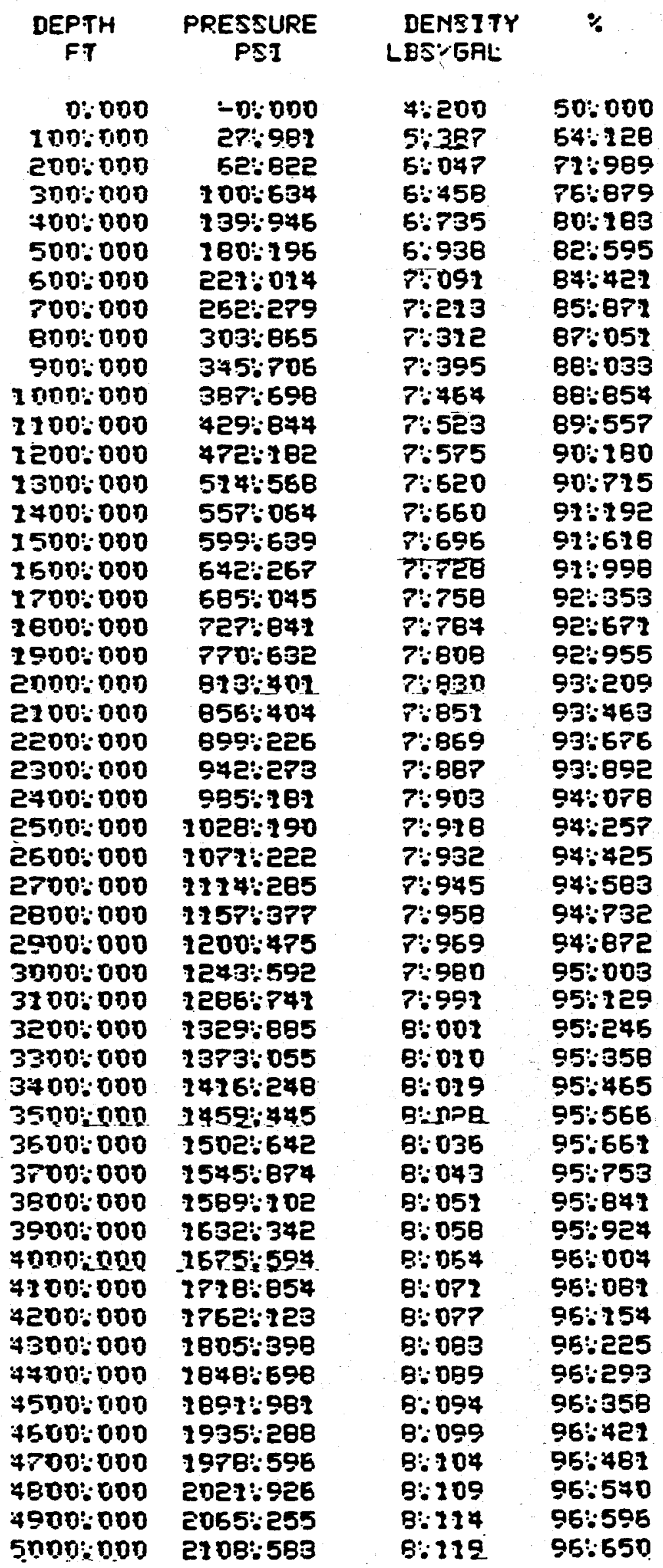

Table 2

Uncut Mud Wt. 9.4 Ppj Wellhead Pressure "O Ratio Air:fluid at "O" gauge $1: 1$ 


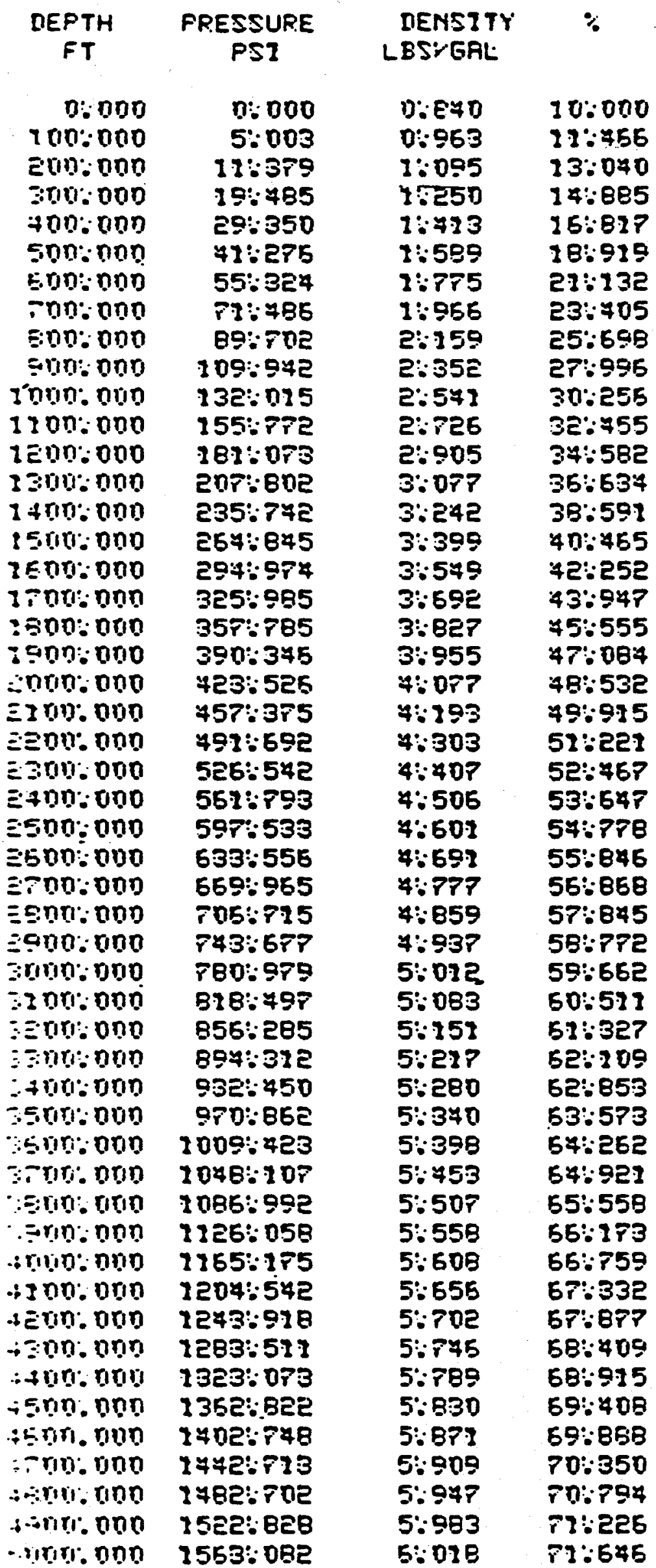

Table 3

Uncut Mud Wt $8.4 \mathrm{ppg}$ Wellhead Pressure "O" Ps Ratio Air:fluid at "O" gauge 10:1 


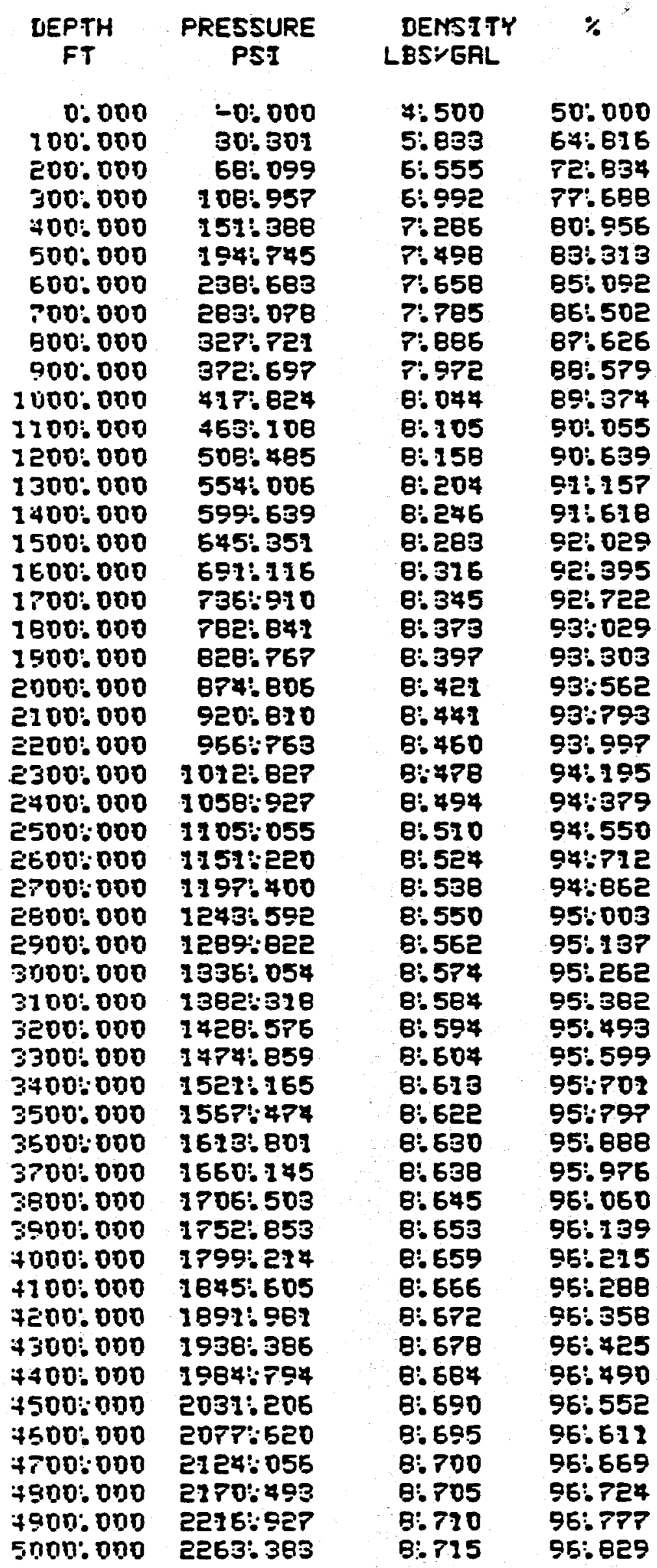

Table 4

Uncut Mud Weight 9 pp!l Wellhead Pressure "O" Ratio Air:fluid at "o" $1: 1$ 


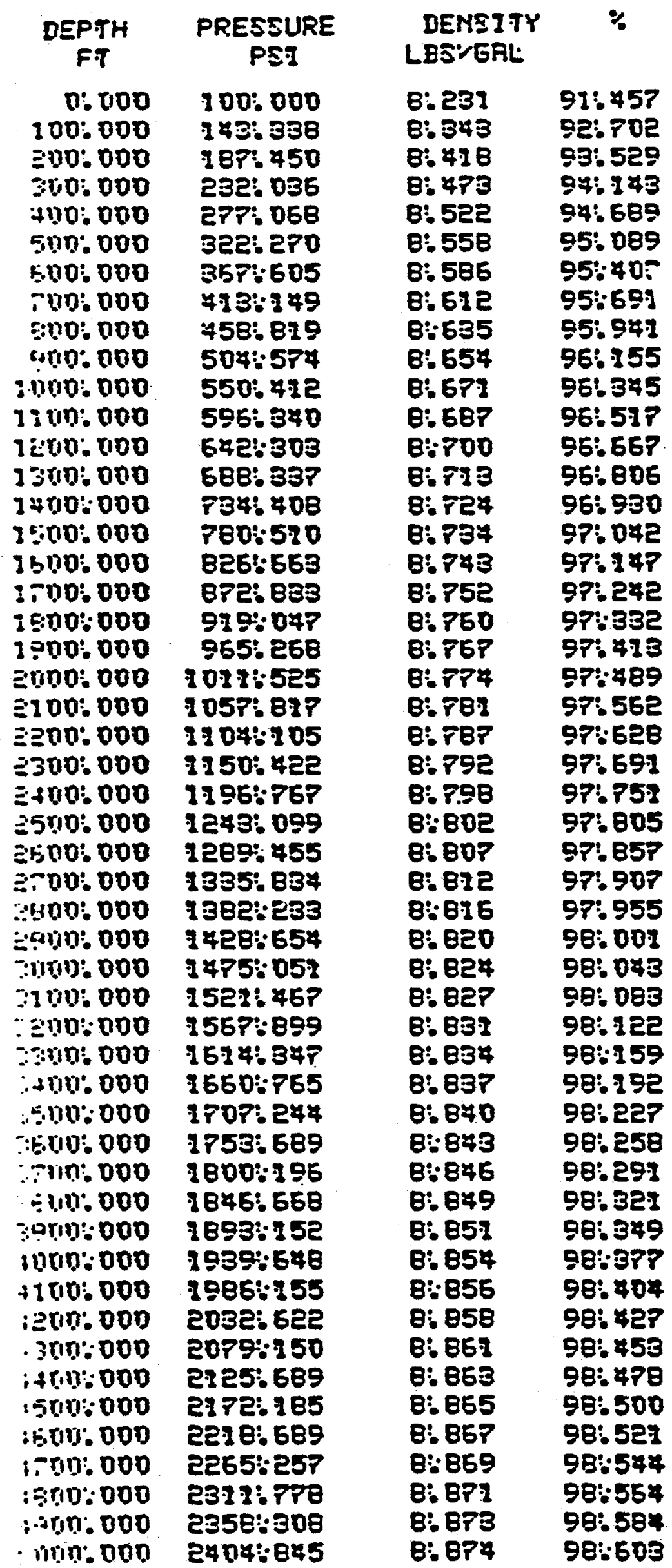

Table 5

Uncut Mud Weight 9 ppg

Wellhead Pressure 100 psi

Ratio Air: Fluid at "O" Gauge $2: 1$ 


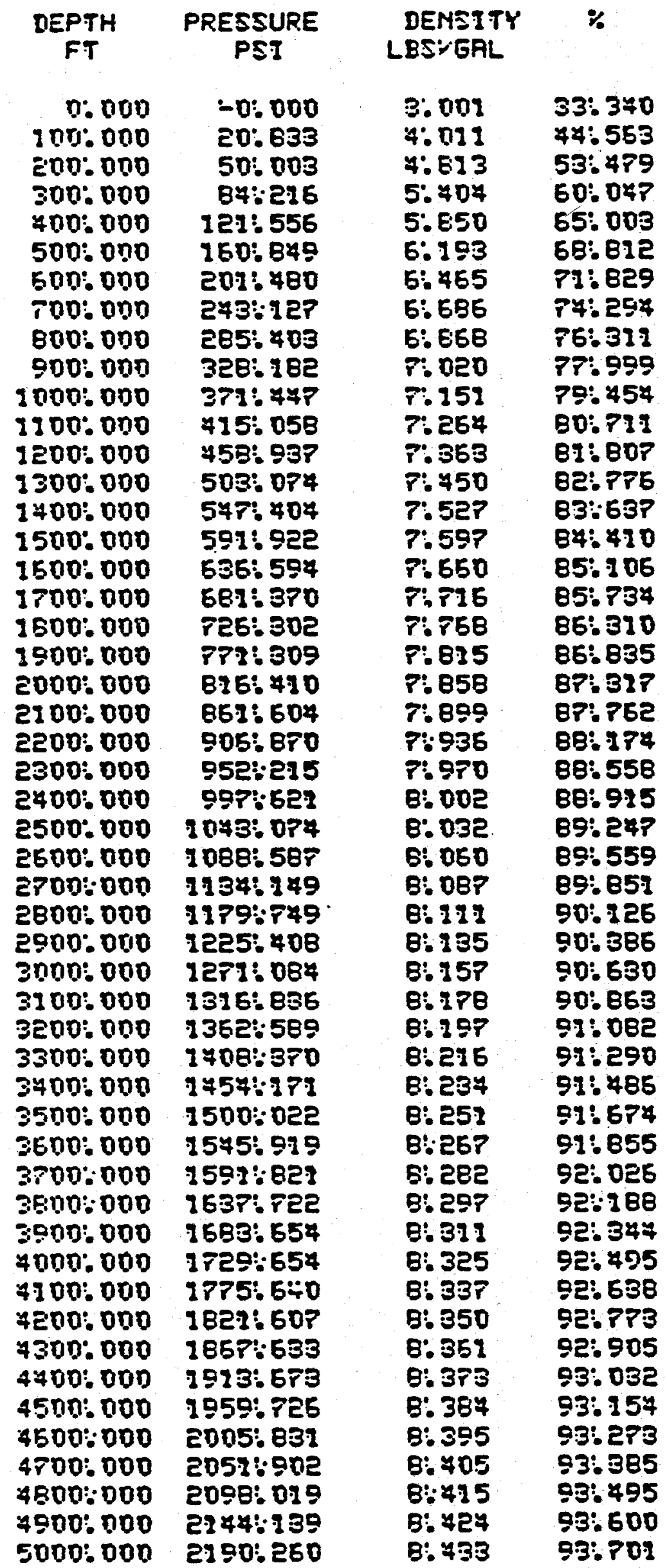

Table 6

Lncut Mud Weight 9 ppg Wellhead Pressure "o" Ratio Air: Fluid at "0" Gauge $2: 1$ 


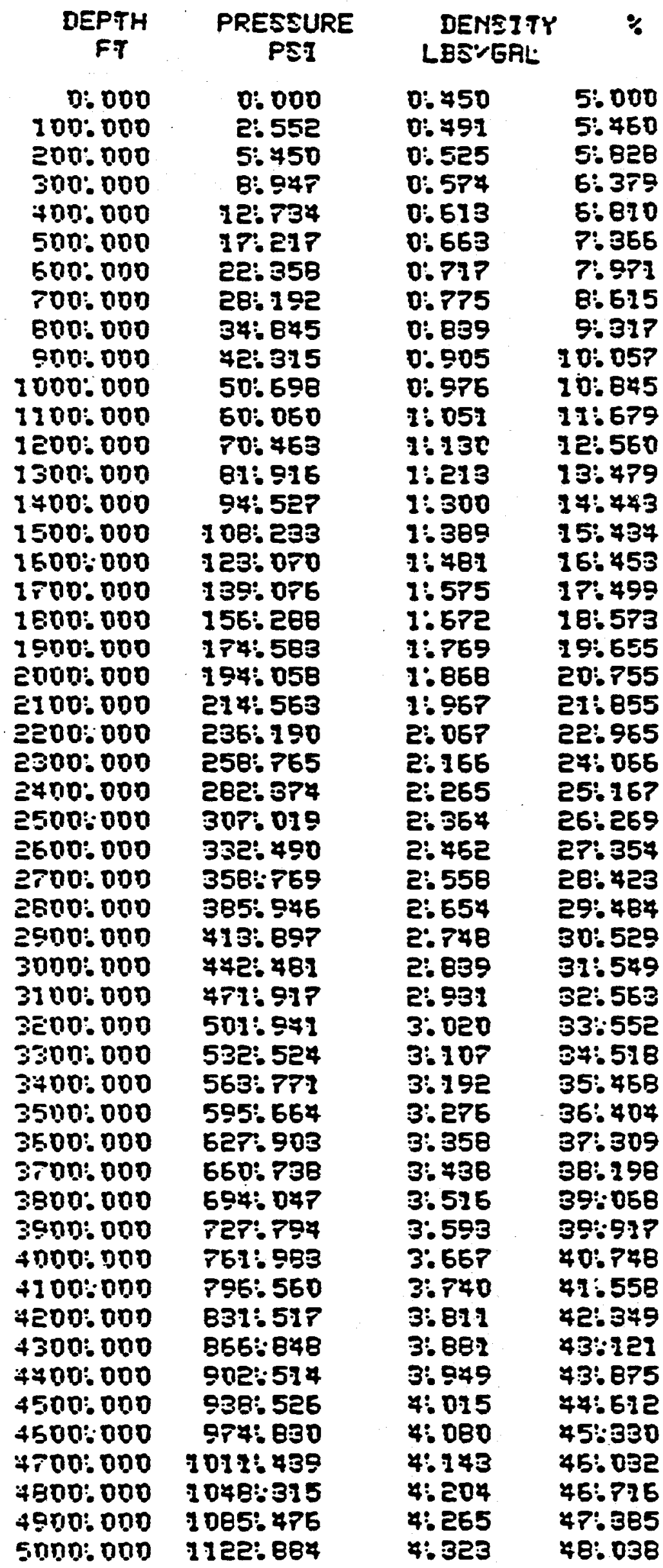

Table 7

Uncut Mud Wt. 9 ppg

Wellihead Pressure "o"

Ratio Air:fluid at "o" 20:1 


\section{BASIC MUD REQUIREMENTS}

There are three basic requirements for drilling. They are the tool, the system for handling the tool, and a method of cleaning the tool cuttings from the hole. Applications of these requirements vary from the small hand drill used by the handyman around his home to the complex drilling rig capable of drilling to 30,000 feet. The drilling rig that is used to explore for natural resources uses a drilling fluld to clean the hole. The drilling fluid used depends upon the situation, but varies from natural gas to weighted drilling mud with a density of 21 ppg.

Normally there are seven functions of a drilling fluid that are basic to its design or use. They are:

1. Clean the bit

2. Clean the hole

3. Lubricate and cool the bit and drill string

4. Control subsurface pressures

5. Support the walls of the hole

6. Suspend cuttings or cavings in the hole when circulation is stopped

7. Support part of the weight of the drill string and casing

The drilling fluid used on any particular project will depend upon the priorities of the above functions and other related problems such as the ability to improve drilling rate and the problems of lost circulation. 
Geothermal drilling fluids are a natural evolution from oil well drilling fluids since oil well drilling on a large commercial scale preceded geothermal work. The development of rotary drilling fluids was affected more and more by temperatures as drilling for oil ands gas went deeper and into areas of higher temperature gradients. The Southwest Texas area, with high-temperature gradients and deep holes, provided many of the first indications of temperature limitations in drilling mud.

The first problems arose with the phosphate thinner used in oil well muds in the 1930s. At the depths drilled in that period $-7,000-10,000$ feet, the bottom-hole temperatures rose above the $150^{\circ} \mathrm{F}$ mark which causes the breakdown of the phosphates.

When lime muds replaced the phosphate treated mud in the 1940s, high-temperature gelation (cementing) occurred at $300^{\circ} \mathrm{F}$ in the deeper hotter holes of that period. It was discovered that the solids content of the mud was, and is, a powerful factor in the destabilization of the mud due to temperature.

Later work resulted in muds with lower pH (low lime muds and gypsum mud) to reduce the high-temperature gelation. It was also learned that lignite and sodium chromate would work effectively to keep muds fluid up to $300^{\circ} \mathrm{F}$.

In efforts to drill deeper and hotter with heavy muds, Mobil oil developed the DMS-DME Sodium Surfactant mud in the 1950s. It had some undesirable properties, but the Ginther well was drilied with bottom-hole temperatures of $450^{\circ} \mathrm{F}$ and mud weights of $18 \mathrm{H} / \mathrm{gal}$ using the sodium surfactant system. 
The introduction of low solid muds in the 1960 s led to the use of asbestos as a bentonite replacement. It was not very successful for that purpose, but it turned out to be a good water thickener for the high temperatures that were just then being drilled at The Geysers in California. The development of sepiolite was a research concept that postulated 'what was nejded was a bentonite that was stable at about $500^{\circ} \mathrm{F} . '$ Mineralogically, this was sepiolite.

Geothermal muds have evolved from this background with cypan and sepiolite being the only present products developed purely for high-temperature mud. This progression is quite logical considering that most geothermal areas are cool enough near the surface to be drilled with conventional muds that are then slowly converted to geothermal systems.

There is, however, a further problem - lost circulation. Lost circulation is probably the single most expensive problem of rotary drilling. In geothermal drilling, the lost circulation problem is accentuated by the fractures in the typical geothermal reservoir rock and the normal extremes of relief in the area. These are problems that are common to oil and gas drilling and mineral exploration, but the altered and fractured nature of geothermal rocks makes the problem of lost circulation in geothermal drilling the dominant control over drilling costs.

The history of oil and gas drilling, and mineral exploration, provides the technical background for lost circulation control. In its most basic form, lost circulation is caused by one or two conditions. 
Condition One - Lost Circulation

The pressure of the drilling fluid column is greater than the fluid pressure in fractured or vugular formations, and the drilling fluid is lost to existing passages. This occurs in areas where the water table is low, such as in areas around the Grand Canyon or on high mesas. The drilling fluid column, if it is water or heavier than water, exerts a greater pressure than the normal formation fluid pressure. Normal formation fluid pressure is generally considered to be equal to the pressure exerted by a column of water to the surface or back.

\section{Condition Two - Lost Circulation}

The pressure of the drilling fluid column fractures the rock and the drilling fluid is lost to the induced fracture.

A term developed for calculating fracture gradients in sedimentary formations is:

$$
\frac{P_{W}}{D}=\left(\frac{S}{D}-\frac{P}{D}\right)\left(\frac{v}{T-v}\right)+\frac{P}{D}
$$

where

$$
\begin{aligned}
P_{w}= & \text { Wellbore Pressure, psi } \\
v= & \text { Poisson's Ratio (horizontal to } \\
& \text { vertical stress ratio) } \\
s= & \text { Overburden Stress, psi (varies } \\
& \text { with depth) } \\
D= & \text { Depth, ft } \\
P= & \text { Formation Pressure, psi }
\end{aligned}
$$


The conditions that cause lost circulation then are basic to the geology of the area. Lost circulation materials are used to help plug the fractures or vugs. The materials are generally wood fibers, nut hulls, cottonseed hulls, etc. The use of lost circulation materials is dependent upon the area, sometimes they are effective, almost always they are expensive, and often they are totally ineffective. Lost circulation is best solved by avoiding it:

To avoid lost circulation, the density of the drilling fluid needs to be reduced to below formation pressure or fracture pressure. Some care needs to be taken in reducing the pressure of the drilling fluid column to below that of the formation fluid, because formation fluid may flow into the well ibore.

Air (or natural gas) was used as a drilling fluid at least as early as the 1930s. Where the formations are strong enough or competent enough so that they would not slough into the hole, and where very little water is produced into the hole, air drilling is very successful. The Geysers in California provide an excellent example of air drilling in the geothermal environment. The upper part of the hole at The Geysers produces too much water to air drili. The bottom of the hole produces only steam and so air drilling is successful.

Air is the best drilling fluid when it can be used because of increased drilling rates in hard rock. It has, however, 1 imitations:

1. Air has poor lifting capacity and large a ir volumes must be used so it is expensive. 
2. Water in the hole compresses the air. This reduces the lifting capacity and also often causes the hole to slough.

3. Formations can produce fluid and gas into the hole to make air drilling impossible.

4. Air drilling is expensive because of the high cost of air compression and the wear and corrosion on the drill pipe.

Mist drilling was developed as a method of coping with water influx into the air drilled hole. A foaming detergent and lime water is added to the air stream in the ratio of water to air of 1:1000 to help form a mist in the air stream. This approach is only partly effective. As the influx volume of water increases, the system tends to go into two phase flow with the water crawling up the side of the hole and the air blowing out the center of the hole. So mist drilling is effective in damp holes or to clean mud rings out of damp holes, but does not solve the problems of fluid influx or sloughing formations.

The obvious approach to the limitations of air drilling was to combine air and drilling mud into aerated mud. This was done as early as the late 1940 s but usually the results were disappointing. The aerated mud or water was generally too expensive, and the system too unstable. Nevertheless, since that time there has been considerable work done with aerated muds. Given close supervision under the proper hole conditions they have performed well in some areas.

Foam was developed as an improvement to aerated mud. The aerated mud was too unstable, so a stable aerated mud was developed. It was so stable, however, it could not be broken down and reused. The mixture looked like aerosol shaving foam, but was stable and persistent. It had a good lifting capacity, was lighter than water and helped support the walls of the hole. 
ABSTRACTS

APPENDIX C

Anderson, Glenn W.: "Near Gauge Holes Through Permafrost,": $0 i l \varepsilon$ Gas Journal, p. 126-142, September 1971 .

Anderson, Glenn W.: "Stable Foam Circulation Cuts Surface Hole Costs," World 0il, Vol. 173, No. 4, p. 39-42, September 1971.

\section{FOAM DRILLING THROUGH PERMAFROST}

Penetration rate of large diameter surface holes drilled through permafrost in Northern Canada has been increased significantly by a stable foam circulating system. It is estimated that use of foam can reduce cost of drilling 800 feet of surface hole as much as $\$ 12,000-\$ 18,000$ oer well.

\section{WHY USE FOAM?}

Due to its excellent insulating properties, low heat capacity and poor heat conductance, stable foam allows driling of a near-gage hole through frozen sections. Stable foam was used in drilling parts of wells where ambient temperature ranged from $-5^{\circ}$ to $-68^{\circ} \mathrm{F}$.

\section{PROBLEMS AND REMEDIES}

The problems encountered while drilling through permafrost with stable foam are:

1. Freezing of the foam

2. Getting formation samples

3. Circulating stable foam from about 1,800 feet due to compressor limitations and low surface temperatures $\left(-70^{\circ} \mathrm{F}\right)$ ect.

A compressor combination with more flexibility should be used. For winter operation some type of heat jacketed line from the foam generator to the rig is essential. An independent water tank, heated and thermostatically controlled for winter use, should be installed for the stable foam process. 
Eleakley, W. B.: "West Texas Workovers with Foam Gain Favor,"

0 il E Gas Journal, Vol. 71, No. 11, p. 97-98, March 1973.

USE OF FOAM IN WEST TEXAS

Stabilized foam permits circulation in wells where water or heavier liquids would be lost to the formation. Standard 0 il Company of California has successfully used stabilized foam, to work over more than 100 wells in West Texas with low bottom hole pressures for cleancut and deepening.

\section{PERFORMANCE OF FOAM}

Stabilized foam with a density of about 2 lb/cu.ft. can be circulated without losing returns and still the foam can remove collected debris or drill cuttings. Even bit cones have been circulated sut successfully. The technique used in drilling a large number of new infill wells in the persian Basin to prevent reservoir damage and loss of drilling fluids is to drill these wells to the top of the pay, set casing, then drill through with foam for an open hole comaletion.

When paraffin is a problem, foam made from water at $200^{\circ} \mathrm{F}$ has been relpful. In wells with high standing water levels, getting circula: ion started without using large air volumes and excess pressure requires special techniques.

\section{ADVANTAGES OF FOAM}

1. Lower move-in cost.

2. Larger cuttings returned.

3. Safer--less combustible.

4. Less corrosive.

5. Moves more formation fluid. 
Jokhoo, Khem,: "Aerated Foam Drilling in Trinidad," Petroleum Engineer, Vol. 48, No. 7, pp. 24-32, June 1976.

GENERAL

Foam has been very successful as a drilling fluid in low pressure, partially depleted areas in Trinidad. 0ld wells drilled with conventional muds presented problems of lost circulation and resulted in low initial potential and ultimate recovery. New wells drilled with foam showed excellent initial potential.

\section{PERFORMANCE OF FOAM}

Foam as experienced in Trinidad is that the foam must be 5 table throughout the system until it leaves the blooie line.

The most successful procedure used in Trinidad to minimize reservoir damage and the loss of drilling filuids to the low pressure formation was to drill the wells to the top of the pay, run and cement casing, and then drill to total depth with foam for an open hole completion with preperforated casing landed opposite the pay zone.

The density of liquid foam-mix commingled with air utilized in Trinidad was as low as $0.27 \mathrm{lb} / \mathrm{gal}$ continuous circulation is almost imperative in foam drilling and it avoids the problem of drill pipe sticking.

\section{COST CONSIDERATIONS}

The cost of a foam rig is higher than a conventional mud rig on a daily basis but on a job basis it might be cheaper to drill a given well with foam than with mud. Drilling costs from top of pay to completion of well were $15 \%$ to $20 \%$ lower for wells drilled with the foam system as compared to the conventional mud system. 
Hutchinson, S. 0. and Anderson, G. W.: "What to Consider When Selecting Drilling Fluids," World Oil, October 1974.

Selecting proper drilling fluids is very important for the economic drilling of wells. Major points to consider when choosing a circulating medium include formation geology, formation pressure, geothermal temperature, makeup water availability and quality, penetration rates, formation evaluation, completion procedures, and ecological considera tions.

The following information pertains to stable foams:

1) Classification and Characteristics

\begin{tabular}{|c|c|c|c|}
\hline $\begin{array}{l}\text { Density } \\
\text { Range }\end{array}$ & $\begin{array}{c}\mathrm{pH} \\
\text { Range }\end{array}$ & $\begin{array}{c}\text { Temperature } \\
\text { Limit }{ }^{\circ} \mathrm{F}\end{array}$ & $\begin{array}{c}\text { Cost } \\
\text { Per Bbl }\end{array}$ \\
\hline $\begin{array}{l}0.56- \\
0.8 \mathrm{ppg}\end{array}$ & $\begin{array}{l}7.0- \\
8.0\end{array}$ & 250 & $\begin{array}{l}\$ 2.50- \\
\$ 3.50\end{array}$ \\
\hline
\end{tabular}

AEC Stiff Foam Gel Mud and Foaming Surfactant

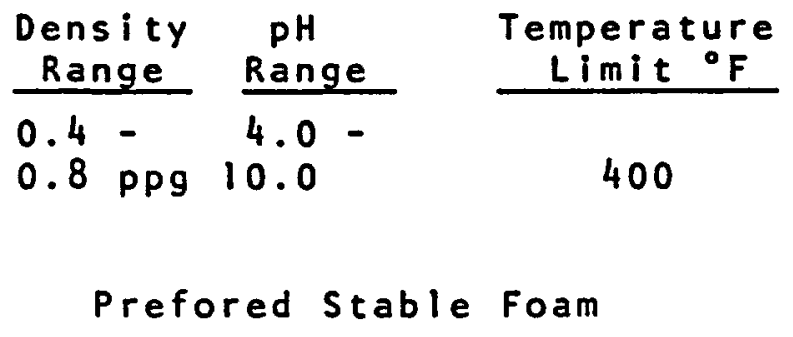

2) Hole Cleaning Capabilities

\begin{tabular}{|c|c|c|}
\hline $\begin{array}{l}\text { Viscosity } \\
\text { Funnel }\end{array}$ & $\begin{array}{c}\text { Hole Size } \\
\text { Inches }\end{array}$ & $\begin{array}{l}\text { Annular } \\
\text { Vel.fpm }\end{array}$ \\
\hline \multirow{2}{*}{$\begin{array}{r}\text { Thick } \\
\text { Stable }\end{array}$} & $9-7 / 8$ & 75 \\
\hline & $17-1 / 2$ & 40 \\
\hline
\end{tabular}

Stable Foam.
Volume

$\frac{(\mathrm{gpm})}{300 \mathrm{cfm}}$
$20 \mathrm{gpm}$
$300 \mathrm{cfm}$
$20 \mathrm{gpm}$

Problem

Excellent cleaning regardless of hole size.

Adequate hole cleaning. Increasing annular velocity annular velocity improves lifting ability and reduces return time. 
Anderson, G. W.: "Foam Disposal - Offshore and Urban Operations,"

Chevron Research Company Foam Cleanout Technical Notes, April 1977.

\section{FOAM DISPOSAL}

Following are the four basic principles for satisfactory foam disposal:

\section{Containment}

To. absorb the violent surge of energy generated by the foam returning at surface at reduced pressure, a vessel or separator must be provided.

\section{Foam Suppression}

a. Foam collapse by expansion in a low pressure chamber.

b. Blending with a large volume of crude oil or produced water from other wells.

c. Chemical foam breakers such as aluminium stearate in diesel oil or water dispersable defoamers in water can be sprayed on the foam surface to break the foam so that the liquids can be pumped or drained off.

3. After the foam has been separated into gas and liquids, it must be subjected to violent agitation or the foam will tend to reform.

4. If natural gas is being used as the gaseous phase, means must be provided to recover or flare the gas. 
Essary, R. L., and Rogers, E. E.: "Techniques and Results of Foam Redrilling Operations - San Joaquin Valley, California," AlME Formation Damage Control Symposium, SPE Paper 5715, PP. 237-244, 1976.

\section{GENERAL}

During the past three years, Standard 0 il Company of California has had a very active foam redrill program in several oil fields in the Southern San Joaquin Valley. Approximately 150 shallow zone wells have been recónditioned by replacing liners using foam redrilling techniques so that the wells could be utilized for steam stimulation and steam flood operations.

\section{ADVANTAGES OF FOAM REDRILLING}

1. The use of low density stable foam provides a practical, economic method for redrilling old low-pressure, high-permeability wells without creating significant formation damage.

2. Redrilling old wells with stable foam provides a substantial savings compared to the drilling of new wells.

\section{LIMITATIONS}

1. Open hole logs cannot be run.

2. Drilled in liners cannot be gravel packed.

3. Intermediate water zones cannot be excluded effectively.

4. Existing small diameter casing would preclude installing satisfactory size liner. 
Bobo, Roy A.: "New Air/Mud System Can Boost Bit Performance," $0 i l \varepsilon$ Gas Journal, May 1968.

Magcobar, Dresser: "Air Drilling Handbook," August 1975.

,: "Modified Stable Foam Can Give Lower Drilling Cost," Petroleum International, Vol. 15, No. 2, February 1975.

GENERAL

It is a confirmed fact that the lower the borehole drilling pressure, the greater is the drilling rate. This effect is more pronounced at higher bit loads. Also, the lower the difference between bottom hole mud pressures and formation fluid pressures, the greater would be the drilling rate (at higher bit loads).

\section{REDUCTION IN BOTTOM HOLE PRESSURES CAN BE ACHIEVED BY:}

1. Aerated Mud: (Air mixed with mud)

a. No lost circulation material cost.

b. Maintain (in some cases increase) drilling rate.

c. Less fluid cost.

d. Less danger of differential sticking of pipe.

2. Dust Drilling: (Air-Drilling)

When properly used can bring faster penetration rates, longer bit

life resulting in fewer round trips, better control of lost circulation, cleaner cores, cleaner formations, etc. can be used only when the formation is completely dry or the water influx is slight enough to be absorbed by the air stream. As the well deepens, more air is necessary to maintain the velocity needed to bring cuttings to the surface.

3. Mist Drilling: (Air plus Foaming Agent)

Mist drilling is used when fluids are encountered. It removes larger cuttings and most of the advantages achieved by straight air drilling are approached. About $30 \%$ to $40 \%$ more air is required for mist drilling (Foam) than for Air-Drilling. Hole sloughing and caving cause most unsuccessful mist drilling jobs because as the hole enlarges, annular velocity drops and the air foam ceases to lift cuttings efficiently.

There is only one drilling situation that precludes the usage of foam drilling and that is where hydrostatic pressure is deemed necessary. (Foam densities varies from 0.4 to $0.8 \mathrm{lb} / \mathrm{gal}$.) 
Hutchinson, S. 0.: "What Foam Is and How It's Used," World Oil, November 1969.

\section{GENERAL}

Stable preformed foam is easy to circulate and relatively inexpensive to produce. It replaces mud, oil, water, air, etc. as a circulating medium in well completion and remedial operations.

\section{ADVANTAGES OF STABLE FOAM}

1. Low Hydrostatic Head: 15 psi @ $1,000 \mathrm{ft}-\mathrm{Actual}^{--}$Actus

$50 \mathrm{psi}$ ¿ 2,900 ft--- Measurements

Problems like formation damage, lost curculation are eliminated.

2. No hole washout in unconsolidated formations while drilling in liners.

3. Excellent carrying capacity for cuttings.

4. Low compression requirements.

5. Low circulating pressures.

6. Stable at high temperatures and bottom hole pressures.

\section{COMPOSITION OF FOAM}

Stable foam consists of a detergent, fresh water, and compressed gas. It must be preformed, i.e., it must be generated out of contact with the solid and liquid contaminants naturally encountered in a well. Foam should have a gas to liquid volume ratio from 3 - $50 \mathrm{cu}$. $\mathrm{ft} / \mathrm{gal}$ depending on downhole requirements. Various gaseous sources used to produce foam include nitrogen, carbon dioxide, natural gas, inert gas air, etc.

\section{PERFORMANCE OF FOAM}

Use of a 2 lb/cu-ft preformed foam circulating medium has speeded well cleanout, reduced sanding problems. Foam has been used successfully on wells deeper than $9,500 \mathrm{ft}$ with tubing pressured to 1,850 psi. 
Magcobar, Dresser: "Stiff Foam," Technical Memorandum, February 1970. WHAT IS FOAM?

Stiff foam is a very stable air-in-mud emulusion formulated with stabilizing mud additives and foaming agents. The system has special application where neither straight air or mist drilling techniques nor aerated muds will suffice because of economic mechanical or other reasons.

WHY USE FOAM?

1. To drill large diameter holes (straight air drilling needs large air volumes).

2. To drill unconsolidated formations. (stiff foam stabilizes this type of formation.)

3. To drill in low pressure or unconsolidated producing zones. (Exerts minimum hydrostatic pressure).

4. To drill water sensitive shales which teno to slough badly when mist drilled.

5. To drill severe lost circulation zones.

COMPOSITION OF FOAM

Stiff foam consists of a thin medium slurry (4-14 gpm) injected with enough air to give a 100 to $200 \mathrm{fpm}$ annular velocity near the surface. Air mud ratios range from 100:1 to 300:1. In order to obtain stable foam, the mud slurry should consist of 12 \#/bbl maglogel, 1 \#/bbl soda ash, $1 / 2$ \#/bbl Hi Vis CMS, $1 / 2$ to $1 \%$ by volume magco foamer $66,1 / 2$ \#/bbl Drispac, and 1 \#/bbl cypan.

\section{PERFORMANCE OF FOAM}

The system is safe, and geological interpretation is facilitated by visual observation at the surface of large cuttings. Penetration rates approaching those obtained with air can be obtained.

\section{LIMITATIONS}

1. High volumes of water or oil limit the true stiff foam approach. Even small amounts of gas can cause troubles.

2. Foam cannot be recirculated.

3. Economical for a depth over $5,000-6,000 \mathrm{ft}$. 
Petroleum Engineering: "Stable Foam Cuts Costs, Increases Production," Vol. 41, No. 13, Pp. 61-63, December 1969.

GENERAL

When used as a circulating medium, stable foam with low density and high solids carrying capacity can reduce workover costs and al increases production.

\section{COST OF FOAM DRILLING}

Heavier units needed for mixing and circulating the foam will cost in the range of $\$ 35,000$ to $\$ 50,000$. Total cost of equipment rentals, chemical usage and royalty payments will range from $\$ 200$ to $\$ 500$ per day.

\section{PERFORMANCE OF FOAM}

Greatest use of the stable foam has been in cleaning out wells with unconsolidated sand formations where severe sandup problems have occurred. Also, foam has proven advantageous over other cleanout methods by stabilizing the sand. In a survey by Standard 0 il Company, twelve wells saved an average of $48 \%$ in sand removal cost, $71 \%$ in future sand entry and $23 \%$ in controllable costs while cumulative production increased $31 \%$.

Stable foam has been effective in reducing the cost of certain fishing operations. Other remedial applications have included circulating in of inner liners, plug-back cementing, recompletions and plugging of old wells. In all cementing operations stable foam has the advantage of minimizing or eliminating lost circulatio because of the low overall hydrostatic head. 
COMPUTER BIBLIOGRAPHY

APPENDIX D.

FLUID

ACCESSION NURBER

TITLE

AUTHORS

SOURCE

ENTRY YEAR

INDEX TERMS
ACCESSION NUMBER TITLE

\section{AUTHORS}

SOURCE

ENTRY YEAR

INDEX TERMS
ACCESSION NUMBER TITLE

SOURCE

ENTRY YEAR

INOEX TERMS
234983

OPERATOR TALK... GLYCOL DEHYORATION

BALLARD D

HYDRCCARBON PROCESS $V$ 56. NO 4. PP 111.118.

APRIL 1977

1977

ABSOREER: ABSORPTION: AESORPTION PROCESS:

ACIOITY/BASICITY: ACTIVITY: CHART: CLEANING:

COLUMN: CONSTRUCTION: CONTAMINATION: CONTROL:

CORROSION: CORROSION CONTROL: CORROSIVITY:

CCST: DDRYING: ECONOMIC FACTOR: ENGLISH:

FILTRATION: FLOW CHART: FOLMING: FREEZING:

- gas DEHYDRATION: - GaS PROCESSING: GAS

PRODUCING: -GLYCOL DEHYDRATION: -HYOROGEN

SULFIOE REPOVAL: INSPECTING: OPERATING COST:

PH: PHASE BEHAVIOR: PHASE CHANGE: PHYSICAL

PROPERTY: PHYSICAL SEPARATION: PIPELINE

CORROSION: PREVENTION: PROCESS CONTROL:

PRODUCING: PURIFYING: REGENERATION:

SEPARATION EOUIPMENT: SOLIDIFICATION:

SORPTION: SORPTION PROCESS: STARTUP: TESTING

234917

AIR. MIST AND FOAM ORILLING: A LOOK AT

LATEST TECHNIOUES

COOPER L W: HOOK R A: PAYNE $B R$

WORLD OIL $V$ 184, NO 5. PP 95-96, 100, 102.

106. APRIL 1977

1977

- AIR DRILLING: aMOCO PRODUCTION CO: BIT PERFORMANCE: BIT (ROCK): CHART: CIRCULATING

RATE: COMPRESSOR: CUTTINGS REMOVAL: DATA:

DRILLING OATA: - DRILLING EOUIPMENT: DRILLING

FLUID: ORILLING PROBLEM: ORILLING RATE:'

-ORILLING (WELL): ENGLISH; FLOW RATE: *FOAM

DRILLING: GRAPH: LOST CIRCULATION: 'MIST

DRILLING: RATE: REMOVAL: -ROTARY DRILLING:

TECHNOLOGY

\section{5}

METHOD OF OPENING CARBON-BEARING GEDS WITH PRODUCTION WELLS FOR UNOERGROUND GASIFICATION LOKSHIN E L: STARINSKY A $A$; VOLK A F

US 4.003 .441 . C 1/18/77. $4 / 22 / 75$

1977

BITUMINOUS DEPOSIT: BITUMINOUS SANDSTONE:

- Casing setT:NG: Casing (WELL): CEMENTING:

CHART: COAL BED: COAL GASIFICATION:

CONVERSION PROCESS: DEPOSIT (GEOLOGY):

DIAGRAM; DRILLING EQUIPMENT: ODRILLING FLUIO:

DEVELOPMENT CORP: -THIXOTROPY: TRISACCHARIOE:

- hater base muo: (D) GREAT BRITAIN 
ACCESSION NUMBER TITLE

\section{AUTHORS \\ SOURCE \\ ENTRY YEAR}

INDEX TERMS

ACCESSION NUMBER TITLE

\section{AUTHORS}

SOURCE

ENTRY YEAR

INDEX TERMS
ACCESSION NUMBER

TITLE

AUTHORS

SQURCE

ENTRY YEAR

INDEX TERHS
233976

THEY SAID IT COULON'T BE DONE. DRILCO SOLVES THE KELLY MUD-LOSS PROBLEM WITH THE MUD-CHEK

KELLY VALVE

DRILLING Y 38, NO 6. PP 28. 60. APRIL 1977 1977

APPLICATION: CHECK VALVE; CONTROL: COST:

DESIGN: DESIGN CRITERIA: ORILL STEM: DRILLING

COST: OORILLING EQUIPMENT: ORILLING FLUID:

DRILLING FLUID COST: - DRILLING PROBLEM:

-DRILLING (WELL): ECONOMIC FACTOR:

ENGINEERING: ENGLISH: KELLY: KELLY JOINT

VALVE: HUD SAVER: OIL GASE MUD: PIPE

HANDLING: PIPE TRIP: POLLUTION CONTROL:

-ROTARY ORILLING: SAFETY: SPECIFICATION:

- valve

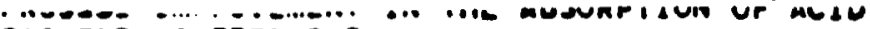

GAS FROM A FEED GAS

GUFFY $U$ C: PAULSON $M$ H: WINKLER R A

U 5 4.002.721. C 1/11/77, F 9/26/74: CHEVRON RESEARCH CO

1977

- $A B S O R B E N T: \angle B S O R B E R: \triangle B S O R P T I O N:$ ABSORPTION

PROCESS: $\triangle O D I T I V E:$ ALCOHOL: BUTYL ALCOHOL:

CARBON DIOXIOE: CARBON DIOXIOE REMOVAL:

CHART: CHEVRON RESEARCH CO: CIRCULATING

SYSTEM: COMPOSITION: COMPOUND: CONTAMINATION:

DATA: DESIGN: DESIGN CRITERIA: DIAGRAM:

-ELUTION: ENGINEERING; ENGLISH: ETHER; FLOW

CHART: FOAM: -FOANING: GAS ABSORPTION: -GAS

FROCESSING: *HYOROCARBON SOLVENT: HYDROGEN

SULFIDE: HYOROGEN SULFIOE REMOVAL: INORGANIC:

KETONE: MIXTURE: NATURAL GAS: ORGaNIC: PATENT

(A): PETROLEUM: PPHYICAL SEPARATION;

PREVENTION: PROCESS DESIGN: PROOUCING OIL +

GAS: PURIFYING: SEPARATION EOUIPMENT:

SOLVENT: -SORBENT: SORPTION: SORPTION

PROCESS: SOUR GAS: SPECIFICATION: SULFIDE:

SURFACE ACTIVE AGENT: SYSTEM (ASSEMBLAGE):

TABLE (DATA): (P) USA

232163

WELL CIRCULATION FLUID FOR USE IN PERMAFROST

ANDERSON $G W$ : HUTCHISON $S 0$

CAN 1.003.200.C 1/11/77. F 3/26/73: CHEVRON

RESEARCH CO

1977

ACDITIVE: -ARCTIC ORILLING: ARTIFICIAL LIFT:

BOREHOLE: CHEVRON RESEARCH CO: CUTTINGS

(ROCK): OORILLING FLUID: ODRILLING (WELL):

ORILLING (WELL) (C): ENGLISH: FOAM: FOAM

ORILLING: FOAM LIFTING: FOAMING: FOAMING

AGENT: FREEZING: -INSULATING MATERIAL:

MIXTURE: PATENT (A): -PERMAFROST: -PERMAFROST

ZONE: PHASE behaviOR: PHASE Change: ROCK

SAMPLE: SAMPLE: SOLIDIFICATION: SUPPLEMENTAL

TECHNOLOGY: "THERMAL INSULATION; WALL: -ZONE

(GEOLOGY): (P) CANAOA 
ACCESSION NUMBER TITLE

AUTHORS

SOURCE

ENTRY YEAR

INDEX TERMS

ACCESSION NUMBER TITLE

AUTHORS

SOURCE

ENTRY YEAR

INDEX TERMS

ACCESSION NUMBER TITEE

AUTHORS

SOURCE

ENTRY YEAR

INOEX TERHS
232033

METHOD FOR COMPLETING A WELL IN A PERMAFROST ZONE

NG $F$ : PERKINS $T K$

U 5 3.995.695,C 12/7/76, F B/25/75: ATLANTIC RICHFIELD CO

1977

ANNULUS: ARCTIC DRILLING: ATLANTIC RICHFIELD

CO: CHART: "ClEANING: COMPOSITION: DENSITY:

DIAGRAM; DISPLACEMENT: ORILLING FLUID:

DRILLING (WELL): ENGLISH: FLOW PROPERTY:

- FLUSHING; FREEZING: LIOUID VISCOSITY: PATENT

(A): PERMAFROST: -PERMAFROST ZONE: PHASE

BEHAVIOR: PHASE CHANGE: PHYSICAL PROPERTY:

PREVENTION: PROCEDURE: SOIL.. (EARTH):

SOLIOIFICATION: VISCOSITY: -WASTE MATERIAL:

-WASTE WATER: WATER BASE MUD: WATER CONTENT:

- WELL CLEANOUT: WELL COMPL SERV + WORKOVER:

-Well COMPLETION: Well wORKOVER: *zONE

(GEOLOGY): (P) USA

232031

FOAMED CEMENTITIOUS COMPOSITIONS AND METHOO

OF PROOUCING SAME

CORNWELL C E: PLUNGUIAN M

U 53.989 .534 , C $11 / 2 / 76$, F 8/29/74

1977

- ADDITIVE: aERATION: LLUMINATE: alUMINOUS

CEMENT: ANION: BENTONITE: CALCIUM ALUMINATE:

CARBOHYDRATE: CASING SETTING: - CEMENT: CEMENT

COMPOSITION: CEMENT SLURRY: CEMENTING: CLAY:

COMPOSITION: COMPOUND: CONCRETE: CONTROL:

DATA: -DENSITY: DEPOSIT (GEOLOGY): ENGLISH:

FILLER: -FOLM: FOAMING: -FOAMING AGENT: GUAR

GUH: GYPSUM: INORGANIC: ION: - LIGHTWEIGHT

CEMENT: MINERAL: -MIXTURE: NATURAL RESIN:

NONIONIC: ORGANIC: PATENT (A): -PHYSICAL

PROPERTY: POLYSACCHARIDE: PORTLAND CEMENT:

STARCH: SULFATE MINERAL: SURFACE ACTIVE

AGENT: TABLE (DATA): WEIGHT: WEIGHT CONTROL:

WELL COMPL SERV + WORKOVER: WELL COMPLETION:

(P) USA

232012

METHOD OF FOAM ORILLING USING A

DI-SUBSTITUTED TAURATE FOAMING AGENT

FISCHER P W: PYE D 5

U 5 3.995.705. C 12/7/76. F 10/24/75; UNION

OIL CO CALIFORNIA

1977

ACIO: -ADOITIVE: ALKALI METAL: ALKANE: ALKYL: AMINO $\triangle$ CIO: AMMONIUM: COMPOSITION: COMPOUND: CONCENTRATION: CUTTINGS REMOVAL: DATA:

- DRILLING FLUID: ORILLING (WELL): ORILLING

(WELL) (C): ENGLISH: ESTEA: FOAM: -FOAM

ORILLING: FOAMING: FOAMING AGENT: -gaS

DRILLING: HIGH TEMPERATURE: HYOROCARBON

COMPOUND: MIXTURE: MOLECULAR STRUCTURE:

MOLECULAR WEIGHT: ORGANIC ACID: PATENT (A):

PHYSICAL PROPERTY: REMOVAL: SALT: SATURATEO HYOROCARBON: STRUCTURE: SULFONATE: SULFONIC ACID: "SURFACE ACTIVE AGENT; TABLE (DATA): TAURINE: TEMPERATURE: UNION OIL CO CALIFORNIA: (P) USA 
ACCESSION NUMBER

TITLE

AUTHORS

SOURCE

ENTRY YEAR

INDEX TERMS

ACCESSION NUMBER TITLE

AUTHORS

SOURCE

ENTRY YEAR

INDEX TERAS
ACCESSTON NUMBER

TITLE

AUTHORS

SOURCE

ENTRY YEAR

INDEX TERIMS
232009

CLAY-FREE THIXOTROPIC WELLBORE FLUIO

HARTFIEL A $H$

U S 3.988,246, C 10/26/76, F 5/24/74:

CHEMICAL ADDITIVES CO

1977

- ADOITIVE: BACTERIA: BRINE: BUSINESS

OPERATION: CARBOHYORATE: CHEMICAL ADDITIVES

CO: COMPOSITION: COMPOUND: DATA: DERIVATIVE

(CHEHICAL): OORILLING FLUID: DRILLING (WELL)

(C): ELEMENT (CHEMICAL): ENGLISH: "FLOW

PROPERTY: FLUID: FLUID PROPERTY: INORGANIC:

LIGNOSULFONATE: - LOW SOLIDS MUD: MAGNESIUM:

MAGNESIUM OXIDE: MANUFACTURING: MUD

ADDITIVE: MUD COMPOSITION: NONNEWTONIAN

FLUIO: ORGANIC MUD ADDITIVE: OXIDE: PATENT

(A): -PHYSICAL PROPERTY: POLYSACCHARIDE:

RHEOLOGY: SALT CONTENT: STARCH: * STARCH MUD:

- organoclar complex: patent (a): phrsical

PROPERTY: - OUATERNARY ARMONIUA COMPND:

RHEOLOGY: SALT: -SILICATE MINERAL: SLURRY:

STEARATE: STEARIC ACID. HYDROXY -: STRUCTURE:

SURFACE PROPERTY: SUSPENSION: TABLE (CATA):

VISCOSITY: WAX: WETTABILITY: (P) USA

230621

APPARATUS FOR SPRAYING AN INSULATING FOAM ON

AN INSIDE WALL OF A TANK

ESTEBANEZ J: LINFIELD P $M$

U S 3,989,006,C $11 / 2 / 76$, F 6/16/75. FR GR

BRIT 6/21/74: SHELL OIL CO

1977

ADJUSTABILITY: APPLYING: CHART: COATING

MATERIAL: - COATING PROCESS: COLUMN: CRYOGENIE

TEMPERATURE: DESIGN: DESIGN CRITERIA:

ENGINEERING: ENGINEERING DRAWING: ENGLISH:

FOAM: - FOAMED PLASTIC: FOAMING: - INSULATING

MATERIAL: INTERNAL COATING: LOW TEMPERATURE:

- MARINE TRANSPORTATION: MIXTURE: MOUNTING:

NONRETALLIC COATING: NOZZLE: PATENT (A):

PIPELINING. SHIP + STORAGE; PLASTIC: PLASTIC

COATING: *POLYMER: SHELL OIL CO: "SHIP:

SPECIFICATION: "SPRAYING: STORAGE FACILITY:

TANK: - TANKER: TEMPERATURE: * THERMAL

INSULATION: TTRANSPORTATION: WALL: (P) USA

230311

'STIFF FOAM' DRILLING

MCCALLUM $R$

I GROUNOWATER ASS S SW AFR V 1. NO 2. PP 4. 12. JULY 1975 (AO)

1977

AIR: *AIR DRILLING: *AIR HAMMER DRILLING:

ANNULAR FLOW: BOREHOLE: OORILLING FLUID:

DRILLING PROBLEM: - ORILLING (WELL): ORILLING

(WELL) (C): ECONOMIC FACTOR: ENGLISH:

EROSION: FLUID: FLUID FLOW: FLUID VELOCITY:

- FOAM: FOAM ORILLING: FOAMING: GAS:

INUECTION PRESSURE: LOST CIFCULATION:

- MIXTURE: -PERCUSSION ORILLING: PRESSURE:

ROTARY DRILLING: SLURRY: SPECIFICATION:

SUSPENSION: VELOCITY: WATER WELL: WEAR: WELL 
ACCESSION NUMBER TITLE

AUTHORS

SOURCE

ENTRY YEAR

INDEX TERMS
ACCESSION NUMBER TITLE

AUTHORS

SOURCE

ENTRY YEAR

INDEX TERMS
ACCESSION NUMBER TITLE

AUTHORS

SOURCE

ENTRY YEAR

\section{4}

LIGHTWEIGHT CELLULAR CEMENT COAPOSITIONS ANO METHODS OF CASTING THE SAME

SUTTON D L

U S 3.979.217.C 9/7/76.F 5/5/75. PR US

6/1/73: HALLIBURTON CO

1977

- adoITIVE: CASING SETTING: -CEMENT: *CEMENT

COMPOSITION: CEMENT HANOLING: CEMENT WATER

RATIO:- CEMENTING: COMPOSITION: CONCRETE:

CONSTRUCTION: CCNSTRUCTION MATERIAL: CONTROL:

DEFORMATION: DENSITY: ENGLISH: FOAH;

FOAMING: FORIING: HALLIBURTON CO:

- LIGHTWEIGHT CEMENT: MIXTURE: MOLDING: PATENT

(A): -PHYSICAL PROPERTY: PROCEDURE:

STABILIZER (ADOITIVE): - SURFACE ACTIVE AGENT: WEIGHT: WEIGHT CONTROL: WELL COMPL SERV + WORKOVER: WELL COMPLETION: (P) USA

\section{3}

GEOTHERMAL WELL ORILLING FLUID TECHNOLOGY -.A LITERATURE SURVEY

GOODE A H: LILES K J: SADLER L Y III

U $S$ EUR MINES INFORM CIRC NO 6724. 28 PP. 1976 1977

ACRYLIC ACIO HOMOPOLYMER: - AODITIVE: ASIA:

ATLANTIC OCEAN: CALIFORNIA; CHROMATE:

COMPOSITION: CONTROL: DATA: DRILLING FLUID:

DRILLING FLUID CONTROL: DRILLING PROBLEM:

- DRILLING (WELL): DRILLING (WELL) (C):

ENGLISH: EUROPE: -EXPLORATION: - EXPLORATORY

ORILLING: FIELD DATA: FLUID PROPERTY:

- GEOPHYSICAL EXPLORATION: GEOTHERMAL

EXPLORATION: HAWAII: MIGH TEMPERATURE:

ICELAND: ITALY: JAPAN: LIGNOSULFONATE: -MUD ADDITIVE: MUD PROPERTY: MUO WEIGHT: NEVADA: NEW ZEALAND: NORTH AMERICA: OCEANIA: PHYSICAL PROPERTY: POLYMER: SEAS AND OCEANS: TABLE (DATA): TEMPERATURE: TURKEY: UNITED STATES: - WATER BASE MUD; WELL TEMPERATURE: WESTERN US: WORLD WIDE

\section{2}

CHEMICAL TREATMENT PROGRAMMES FOR INJECTION WATER:-- AN INSTRUMENTATION PACKAGE FOR NORTH SEA FIELDS

BAKER C: WITHERS A

PETROL TIMES V 80. NO 2036. PP 23. 25.27. $10 / 1 / 76$

1976

-TRANSITION TEMPERATURE: WATER: WATER BASE MUO: WATER CONTENT: WELL COMPL SERV + WORKOVER: -WELL COMPLETION: -ZONE (GEOLOGY): (P) USA

227120

THE POTENTIAL OF STABLE FOAM

MITCHELL T

OILWEEK V 27, NO 35, P 11. 10/11/76

1976

AIR ORILLING: ALBERTA: CANADA: CASE HISTORY: COMPARISON: CONTAMINATION: CONTROL: DATA: -ORILLING FLUID: DRILLING PROBLEM: -DRILLING (WELL): DRILLING (WELL) (C): ENGLISH: -FOAM: - FOAM DRILLING: FOOTHILLS STRUCTURE: 
FREEZING: GENERATOR: INSULATING MATERIAL: LIMIT: -LOST CIRCULATION: MINIMUM: MIXTURE: MOUNTAIN: NEWS: NORTH AMERICA: PHASE

BehaVIOR: PHASE CHANGE: - PHYSICAL PROFERTY; SAFETY: SHELL CANADA LTO: SOAP;

SOLIOIFICATICN: -STABILITY: THERMAL INSULATION

ACCESSION NUMBER

TITLE

AUTHORS

SOURCE

ENTRY YEAR

INDEX TERMS

ACCESSION NUMBER

TITLE

AUTHORS

SOURCE

ENTRY YEAR

INDEX TERMS
ACCESSION NUMBER TITLE

\section{AUTHORS}

SOURCE

ENTRY YEAR INDEX TERMS

\section{5}

TAR SANDS TREATMENT

SMITH R H

CAN 993.392. C 7/20/76.F 10/3/73, PR US 7/9/73: ATLANTIC RICHFIELD CO

1976

ALT FUELS + ENERGY SOURCES: ATLANTIC RICHFIELD CO: -BITUMINOUS SANDSTONE: CENTRIFUGE: CENTRIFUGING: CCRUDE OIL: DESIGN: DESIGN CRITERIA: DILUTING: DISPOSAL: DRYING: ENGINEERING: ENGLISH: FOAM: FOAMING:

GRAVITATIONAL SEPARATION: FOT WATER: - ManUfactured CRUDe oIl: mechanical

DEHYDRATION: MIXTURE: OIL ANO GAS RECOVERY: - OIl RECOVERY: PARTICLE: PATENT (A):

- PETROLEUM: PHYSICAL SEPARATION: PROCESS OESIGN: RECOVERY PROCESS: RESIDUE: -ROCK: - SANDSTONE: - SEDIMENTARY ROCK: SEPARATION EOUIPMENT: SOLID: SPECIFICATION: STEAM: STRIPPING: -TAR SAND: TAR SAND OIL: -TAR SAND OIL RECOVERY: WATER: WATER DISPOSAL: WATER VAPOR: (P) CANADA

223382

LERATED FOAM DRILLING IN TRINIDAD JOKHOO $\mathrm{K}$

PETROL ENG V 48, NO 7. PP 24, 26, 28, 32. JUNE 1976

1976

CASING SETTING: CENOZOIC: CENTRAL AMERICA:

COST: CUTTINGS REMOVAL: DATA: DRILLING COST: DRILLING DATA: DRILLING EOUIPMENT: - DRILLING FLUIO: DRILLING PROBLEM: ODILLING PROGRAM: DRILLING RATE: - ORILLING (WELL): DRILLING (WELL) (C): EARTH AGE: ECONOMIC FACTCR: ENGLISH: FLUID PROPERTY: FOAM: FOAM

DRILLING: FORMATION (GEOLOGY): GEOLOGIC STRUCTURE: GUAYAGUAYARE OIL FIELD:

INCOMPETENT BED: LESSER ANTILLES: LOST CIRCULATION: LOW PRESSURE: MIOCENE: MIXTURE: MUO PROPERTY: MUD WEIGHT: OIL AND GAS FIELDS: OIL FIELD: OIL RESERVOIR: PHYSICAL PROPERTY: PIPE STICKING: PRESSURE: REMOVAL: RESERVOIR: SANDSTONE RESERVOIR: TERTIARY PERIOD:

- TRINIDAD: TRINIDAD AND TOBAGO: UNCONSOLIDATED FORMATION: OUNUSUAL DRILLING CONDITION: WELL LOGGING: WEST INOIES

222543

THE EFFECT OF POTASSIUM-SALT MUDS ON GAMMA RAY, AND SPONTANEOUS POTENTIAL MEASUREMENTS COX J W: RAYMER L L 17TH ANNU SPWLA LOGgING SYMP TRANS $20 \mathrm{FP}$. 1976 (PAPER NO II)

1976

BICARBONATE: BUSINESS OPERATION: CHEMISTRY:

CHLORIDE: - DRILLING FLUIO: "ELECTRIC LOGGING: ELECTROCHEMISTRY: ELEMENT (CHEMICAL): ENGLISH: EVALUATION: FILTRATE: FLUID 
PROPERTY: FORMATION DAMAGE: FORMATION EVALUATION: "GAMAMA RAY LOGGING:

- INTERPRETATION: INVAOED ZONE: ION: ISOTOPE:

- MINERAL: MUD PROPERTY: MUD RESISTIVITY:

- NUCLEAR LOGGING: PHYSICAL PROPERTY:

POTASSIUM: POTASSIUM GICAREONATE: POTASSIUA

CHLORIDE: - POTASSIUM MINERAL: RADIOACTIVE

ISOTOFE: RADIOACTIVE MINERAL: RADIOACTIVITY:

- SAlt water MUD: - SELF potential lOGgING:

THERMAL PROPERTY: "WATER BASE MUD: -WELL LOG

INTERPRETATION: WELL LOGGING: WELL LOGGING * SURVEYING

STAEILIZATION: HYDRAULICS: MUD ADOITIVE: "MUD CONPOSITION: -MUD PROGRAM: NORTH AMERICA:

OKLAMONA: STABILIZATION: TEMPERATURE: TEXAS:

UNITED STATES: - UNUSUAL DRILLING CONDITION:

USA: WATER GASE MUO

ACCESSION NURIBER

TITLE

AUTHORS

SOURCE

ENTRY YEAR

INDEX TERMS
ACCESSION NUMEER

TITLE

AUTHORS

SOURCE

ENTRY YEAR

INDEX TERMS
219176

FORMATION FRACTURING WITH STABLE FOAM

BLAUER R E: DURECROW J

U 53.937 .283 . C 2/10/76.F 10/17/74: DOW CHEMICAL CO. MINERALS MANAGEMENT INC 1976

ACID: ADOITIVE: AIR: BLOCK DIAGRAM: CAREON

DIOXIDE: CHART: COMPOSITION: COMPOUND: COMPRESSEO GAS: DIAGRAM: DOW CHEMICAL CO:

ELEMENT (CHEPICAL): EMULSION: ENGLISH:

FISSURE (GEOLOGY): FLUIO: FOAIA: FOAMING:

FRACTURE EXTENSION: FRACTURE (ROCK):

- FRACTURING: - FRACTURING FLUID: FRACTURING

PRESSURE: GAS: GAS INJECTION: GEOLOGIC

STRUCTURE: GRAPHICAL REPRESENTATION:

- HYORAULIC FRACTURING: INDUCED FRACTURE:

INJECTION: LIOUID: MATHEMATICAL ANALYSIS:

MATHEMIATICS: MINERALS MANAGEMENT INC: MIXING:

- MIXTURE: NITROGEN: OIL: ORGANIC: PATENT (A):

- PHYSICAL PROPERTY: PRESSURE: PROCEDURE:

OUALITY: - STABILITY: SURFACE ACTIVE AGENT:

TEMPERATURE: WATER: WELL COMPL SERV +

WORKOVER: WELL COMPLETION: WELL STIMULATION:

(P) USA

218874

METHOD OF RECOVERING OIL USING STEAM

NEEDHAN $R$ B

U S APPL B 529.836. F 12/5/74: PHILLIPS

PETROLEUM CO

1976

ADOITIVE: CHEMICAL INJECTION: CRUDE OIL:

ENGINEERING: ENGLISH: FOAH: FOAMING: FOAMING AGENT: - FORMATION PLUGGING: GEOLOGIC

STRUCTURE: INJECTION: INJECTION WELL:

INJECTIVITY: *INJECTIVITY PROFILING:

- MIXTURE: OIL AND GAS RECOVERY: OIL

PRODUCING: OIL RECOVERY: OIL RESERVOIR:

PATENT (A): PETROLEUM: PETROLEUM ENGINEERING:

PHILLIPS PETROLEUA CO: PHYSICAL PROPERTY:

- PLUGGING: PLLUGGING AGENT: PRODUCING:

PRODUCING WELL: PROFILING; RECOVERY

CATEGORY: -RECOVERY PROCESS: RESERVOLR:

RESERVOIR ENG + REC METHOO: RESERVOIR

ENGINEERING: SECONDARY RECOVERY: STEAM: 
ACCESSION NURBER IITLE

AUTHORS

SOURCE

ENTRY YEAR.

INDEX TERMS
ACCESSION NUMBER TITLE

\section{AUTHORS}

SOURCE

ENTRY YEAR

INDEX TERMS
ACCESSION NUMBER TITLE

\section{AUTHORS \\ SOURCE \\ ENTRY YEAR \\ INDEX TERMS}

ACCESSION NUMBER

TITLE

AUTHORS

SOURCE

ENTRY YEAR

INDEX TERMS
218057

CCMPOSITION AND PROCESS FOR DEFOAMING

ORILLING FLUIDS

ELTIIHG K A C

US 3.920.559. C 11;18/75.F 2/19/74: MILCML

INC

1376

ACID: - $D D O I T I V E:$ ALCCHOL: ALUMINUM STEARATE:

- ANTIFOAMING AGENI: CALCIUM STELRATE:

COMPOUNO: CONTROL: DATA: DEFOAMING:

-DEGASSING: -DRILLING FLUID: -DRILLING FLUID

CONTROL: DFILLING (WELL) (C): ENGLISH: ESTER: FCAIA: INHIEITION: IRON STEARATE: MILCHEM INC: HIXTURE: OLEYL ALCOHOL: ORGANIC: ORGANIC ACIO: ORGAACMETALLIC CCMPCUND: PATENT (A): - PHYSICAL SEPARATICN: PROPYLENE OXIDE: SALT: SOAP: STEARATE: STEARIC ACIO: SURFACE ACTIVE AGENT: -SYNERGISTIC EFFECT: TABLE (DATA):

- WaTER BASE mUD: ZINC STEARATE: (P) USA

217859

TECHNICUES AND RESULTS OF FOAM REDRILLING OPERAIIONS--SAN JOAOUIN VALLEY. CALIFORNIA ESSARY R L: ROGERS E E 2ND SPE OF AIME FORMATION DAMAGE CONTR SYMP PREPRINT NO SPE-5715. PP 237-244, 1976 1976

CALIFORNIA: CASE HISTORY: - CIRCULATING SYSTEM: COST: CUTTINGS REMOVAL: DATA: DRILLING COST: -DRILLING FLUID: -DRILLING (WELL): ECONOMIC FACTOR: ENGLISH: FOAM: -FOAM DRILLING: FORMATION DAMAGE: INUECTION WELL: - LINER COMPLETION: LOW PRESSURE: MIXTURE: NORTH AMERICA: PRESSURE: RECOVERY PROCESS: REMOVAL: SAN JOAQUIN BASIN: "SHALLOW WELL: STANDARO OIL CO CALIFORNIA: STEAM INJECTION: - SYSTEM (ASSEMBLAGE): THERMAL RECOVERY: UNITED STATES: *WELL: WELL COMPL SERV + WORKOVER: "WELL COMPLETION

217844

PREFORMEd STABLE fOAM PERformanCE IN DRILLING EVALUATING SHALLOW GAS WELLS IN NORTHEASTERN ALBERTA

BENTSEN $N W$ : VENY J $N$

2ND SPE OF AIME FORMATION DAMAGE CONTR SYMP PREPRINT NO SPE-5712. PP 213-218. 1976

1976

- ADOITIVE: -ALBERTA: CANADA: CAPACITY (ROCK): CIRCULATING SYSTEM: CORING: CUTTINGS REMOVAL:

212005

FOAM RECOVERY PROCESS

RoOT $P J$

US 3.893.511. C 7/8/75. F 6/9/71: SUN 01L CO 1975

aODITIVE: CAREON DIOXIDE: - CARBON DIOXIDE

INJECTION: CHEMICAL: CHEMICAL INJECTION:

COMPCUND: - CONTROL: CRUDE OIL: CYCLIC

INJECTION: EFFICIENCY: ENGINEERING: ENGLISH:

FLOODING (FORNATION): -FLOW CONTROL: -FLUIO

ENTRY PROF ILING: FLUID FLOW: FOAM: FOAM

FLOCDING: FOAMING: FOAMING AGENT: FORMATION DARAGE: -GAS ENTRY PROFILING: - GAS INJECTION: GEOLOCIC SIRUCTURE: HETEROGENEITY: IN SITU: 
- INJECTION: INJECTION WELL: INJECTIVITY: INJECTIVITY PROFILING: -MIXTURE: OIL RECOVERY: OIL RESERVOIR: ORGANIC: PATENT (A): PERMEABILITY: PERHEABILITY (ROCK): PETROLEUR: PETROLEUM ENGINEERING: PHYSICAL PROPERTY: - PROFILING: -RECOVERY: RESERVOIR: RESERVOIR ENG + REC METHOD: RESERVOIR ENGINEERING: - SECONDARY RECOVERY: SUN OIL CO: SURFACE ACTIVE AGENT: SWEEP EFFICIENCY: WELL: (P) USA

ACCESSION NUMBER

TITLE

AUTHORS

SOURCE

ENTRY YEAR

INDEX TERMS
ACCESSION MUMBER

TITLE

AUTHORS

SOURCE

EMTRY YEAR

INOEX TERMS
ACCESSION MUMBER

TITLE

AUTHORS

SOURCE

ENTAY YEAR

INOEX TERUS
211954

FOAM PRESSURE LOSS IN VERTICAL TUBING

KRUG $J A$

OIL GAS $\ \vee 73$, NO 40, PP 74-76, 78, 10/6/75

1975

-artificial lift: calculating: change:

CHART: COEFFICIENT OF FRICTION: CONTROL:

DATA: -DECREASE: DENSITY: DIAMETER: CRILLING

(WELL): -EMPIRICAL ANALYSIS: ENGLISH:

EOUATION: EXAMPLE: FANNING FRICTION FACTOR:

FLOW PROPERTY: FLUIO FLOW: FOAM: FOAM

ORILLING: "FOAM LIFTING: FOAMING: FRICTION:

*FRICTION LOSS (FLUID): GRAPH: *GRAPHICAL

SOLUTION: LAMINAR FLOW: -LOSS: "MATHEMATICAL

ANALYSIS: MATHEMATICAL MODEL: "MATHEMATICS:

MECHANICAL PROPERTY: MIXTURE: MODEL:

MULTIFHASE FLOW: PHYSICAL PROPERTY: PIPE

DIAHETER: PRESSURE: "PRESSURE DECLINE:

QUALITY: OUALITY CONTROL: REYNOLDS NUMBER:

- TRANSMISSION LOSS: TUBE: TUEING (WELL):

TUBULAR GOODS: TURBULENT FLOW: VERTICAL:

VISCOSITY: WELL COMPL SERV + WORKOVER; YIELO POINT

205152

APPARATUS FOR GENERATING ANO PUMPING FOAM

ERON R E

GR BRIT 1,387,975, C 3/19/75, F $2 / 26 / 73$

1975

- ADDITIVE: AGITATING: AGITATOR: AIR DRILLING:

-ARTIFICIAL LIFT: CLEANING: OORILLING (WELL):

ORILLING (WELL) (C): ENGLISH: -FIRE FIGHTING:

- FLOODING (FOFMATION): FOAM: -FOAM DRILLING:

- foAm Flooding: - foam lifting: * foaming

AGENT: GAS DRILLING: GENERATOR: MEASURING:

METERING: MIXTURE: NOZZLE: PATENT (A):

PHYSICAL PROPEATY: PUMPING: -RECOVERY: SOAP:

STABILITY: STABILIZER (ADDITIVE): SURFACE

ACTIVE AGENT: TESTING: WELL CLEANOUT: (P)

GREAT BRITAIN

\section{6}

FOAMED CONCRETE STRUCTURES

ERGENE M T

U S 3.867.159, C 2/18/75,F 9/10/73, PR US

10/22/70; STANLEY WORKS

1975

- AOOITIVE: ADHESIVE: CASING SETTING: CAVITY: - CERENT: -CEMENT ACCELERATOR: CERENT

ADOLTIVE: *CEMENT COMPOSITION: CEMENTING:

CHEMICAL: CHLORIDE: COMPOSITION: COMPOUND:

CONCENTRATION: DENSITY: ENGLISH: FIBER:

- FOAII: FOAHING: *FOAMING AGENT: FORMING;

INORGANIC; -LIGHTWEIGHT CEMENT: MIXTURE:

MOLOING: PATENT (A): PHYSICAL PROPERTY:

POLYMER: PORE: PORE SIZE: POROSITY: PRESSURE:

PROCEOURE: REINFORCING AGENT: STANLEY WORKS:

SYNTHETIC RESIN: WELL COMPL SERV + WORKOVER:

WELL COMPLETION: (P) USA 
ACCESSION NUMBER TITLE

\section{AUTHORS \\ SOURCE \\ ENTRY YEAR \\ INDEX TERMS}

ACCESSION NUMBER TITLE

SUTHORS

SOURCE

ENTRY YEAR

INDEX TERA:S
ACCESSION NUMBER TITLE

AUTHORS

SOURCE

ENTRY YEAR

INDEX TERHS
204908

hoolf IED stagle foAm Can give lower dRILling

COSTS

HIGGINS $B$

PETROLEUM INT $V$ 15. NO 2, PP 12-14, 16. FEB

1975

1975

AFTIFICIAL LIFT: CAFRYING CAPACITY: COST:

CUTTINGS REMOVAL: -ORILLING COST: ORILLING

FLUIO: - DRILLING FLUID COST: DRILLING FLUID HYDRAULICS: -DRILLING (WELL): DRILLING (WELL)

(C): -ECONOMIC FACTOR: ENGLISH: FLOW

PROPERTY: FOAM: FOAM DRILLING: FOAM

LIFTING; HYDRAULICS: -MIXTURE: PHYSICAL

\section{2}

CLOSED CIRCUIT METHOD OF CLRCULATING A SUBSTANTIALLY SOLID FREE ORILLING FLUID JACKSON J Hi

U S 3.844.361. C 10/29/74. F 4/19/73. PR US $12 / 23 / 70$

1975

ADDITIVE: CALCIUM CHLORIDE: CATION: CHANGE:

CHEMICAL: CHLORIOE: - CIRCULATING:

- CIRCULATIRG SYSTEM: Clay SWELLING: *Closed SYSTEA: - CCIAFOSITION: CCMIPOUND:

CONTALIINAT!ONA CCNTROL: CUTTINGS REROVAL; CUTTINGS (ROCK): -ORILLING FLUID: DRILLING

FLUID CONTFOL: DRILLING FLUID HYORAULICS:

- DRILLIHG FLUIO SYSTEM: DRILLING (WELL):

ELECTROLYTE: ENGLISH: EXFANSION: FLCW

FROPERTY: MYORAULICS: HYDROXYETHYL CELLULOSE:

INHI8!TOR: INORGANIC: IOH: - LOW SOLIOS MUD:

- MUD COMPOSITION: MUD SEPARATOR: MUD

VISCOSITY: ORGANIC: PATENT (A): PHYSICAL

PROPERTY: FREVENTION: REMOVAL: ROCK SAMPLE: ROTARY ORILLIHG: SALT: SAMPLE: SCREEN: SEPARATION EQUIPMENT: SHALE SHAKER: SODDIUM CHLOR:DE: SURFACE ACTIVE AGENT: - SYSTEM (ASSER:BLAGE): VISCOSITY: WATER: WATER BASE MUD: (P) USA

200217

SILICATE FOAM STRUCTURES ANO METHOD OF PREPARATION

HORAI J C: SHEELER C W JR

U S 3.844,804, C 10/29/74,F 1/3/72: GAF CORP 1975

ACIO: ALKaLI METAL: -CEMENT: CHEMICAL:

CHEMICAL REACTION: COMPOSITION: COMPOUND: CONCENTRATION: *CONSTRUCTION MATERIAL:

-DENSITY: ENGLISH: -FOAM: FOAMING: FORMING:

GAF CORP: HEATING: IN SITU: INORGANIC:

- LIGHTWEIGHT CEMENT: MECHANICAL PROPERTY:

- MECHANICAL STRENGTH: - MIXTURE: MOLDING:

PATENT (A): PHOSPHORIC ACID: PHYSICAL

PROPERTY: POTASSIUM SILICATE: SILICATE:

SODIUM SILICATE: SOLUBILITY: TEMPERATURE:

WATER SOLUBILITY: (P) USA

SURFACE TENSION: TABLE (OATA): TESTING: THIN FILM: VVELOCITY: VISCOSITY: WATER: "WAVE VELOCITY 
ACCESSION NUMBER

TITLE

SOURCE

ENTRY YEAR

INDEX TERMS
ACCESSION NUMBER TITLE

AUTHORS

SOURCE

ENTRY YEAR

INDEX TERUS

\section{ACCESSION NUMEER TITLE \\ AUTHORS \\ SOURCE \\ ENTRY YEAR \\ INDEX TERMS}

\section{ACCESSION NUMBER} TITLE

SOURCE

ENTRY YEAR

INDEX TERMS
197598

EXIINGUISHING LIOUIO HYOROCARBON FIRES

AUSTRAL 453.734: C 10/10/74. F 4/29/69. PR US 4/30/68: UNION CARBIDE CORP

1974

ADOITIVE: CHAHGE: CHEMICAL: COMEUSTION:

- COMFOUND: DECREASE: ENGLISH: -FILM: FIRE :

- FIRE FIGHTING: FLARIAABILITY: FLUID: - FOAM;

- FOANIING: FOAHINC AGENT: HYOROCARBON

COHPOUND: LIOUID: MIXTURE: PATENT (A):

PHYSICAL PROPERTY: SAFETY: SILICONE:

SOLUBILITY: SUPPLEMENTAL TECHNOLOGY: SURFACE

ACTIVE AGENT: SURFACE PROPERTY: SURFACE

TENSION: THIN FILIA: UNION CARBIDE CORP:

WETTAEILITY: (P) AUSTRALIA

197490

METHOD OF PRODUCIHG AND USING \& GELLED OIL

BISE PACKER FLUID

MCNDSHINE T C

U S 3.831.678.C 8/27/74.F 5/2/73:N L

INOUSTRIES INC

1974

- LODITIVE: aSBESTOS: CLAY: COMPOSITION:

CONCENTRATION: -CCNTROL: DATA: DEPOSIT

(GEOLCGY): DISPERSANT: OISPERSING: ORILLING

FLUIO: ENGLISH: FERRCMAGNESIAN MINERAL: GEL:

GELATION: "GELLIMG AGENT: HEAT: HEATING: IN

SITU: MINEAAL: MIXTURE: N L INDUSTRIES INC:

OIL EASE MUD: - PACKER FLUID: PATENT (A):

PHASE BeHAVIOR: PHASE CHANGE: PROCEDURE:

SILICATE MINERAL: TABLE (OATA): TEMPERATURE:

- TEMPERATURE CONTROL: VISCOUS OIL: WELL COMPL

SERV + WORKOVER: WELL COMPLETION: -WELL

SERVICING: WELL WORKOVER: (P) USA

197130

DRILLING PROGRESS. PT, 1. EACH DRILLING

FLUID HAS A SPECIFIC APPLICATION

ANDERSON G W: HUTCHISON 50

WORLD OIL V 179. NO 5. PP 84-86, OCT 1974 1974

ACIOITY/BASICITY: ADOITIVE: AIR: APPLICATION:

CHART: CLASSIFICATION: COMPOSITION:

- CONTROL: COST: DATA: DENSITY: DIAGRAM:

195118

AIR CR!LLING WAY PLAY ROLE IN GROWING DEEP LPPALACHIAN PLAY

OIL GAS U $V 72$, NO 38. PP $136 \cdot 138,9 / 23 / 74$ 1974

ADOITIVE: HIF DRILLING: APPALACHIAN BASIN:

ARTIFICIAL LIFT: CARRYING CAPACITY: CASING

SETTING: CASING SIRING DESIGN: CEMENTING:

CHART: COLUAIAAR SECTION: COST: CUTTINGS

RENOVAL: DEEP CRILLING: DESIGN: DRILLING

COST: DRILLING PRCBIEH: DRILLING PROGRAH:

ORILLING RIG: DRILLING (WELL): DRILLING

(WELL) (C): ECOI:CMIC FACTOR: ENGINEERING:

ENGLISH: EXPLORATORY ORILLING: FLOW

PROPERTY: FOAM: FOAM ORILLING: FOAM LIFTING:

FOAMING AGENT: FOFHATION DAMAGE: -GAS

ORILLING: "GAS RESERVE: HOLE CAVING: HOLE

DEVIATION: HOLE STABILIZATION: LANO ANO

LEASING: MIXTURE: N:UD PGCGRAM: NEWS: NORTH

AOERICA: PHYS:CAL FROPERTY: PIPE STICKING:

PROGRAM: REBOVAL: -RESERVE: SALT BED:

SHORTAGE: SLCUGHING SHALE: STABILIZATION:

HATER ENTRY: WEST VIRGINIA 
ACCESSION NUMBER TITLE

AUTHORS

SOURCE

ENTRY YEAR

INOEX TERMS
ACCESSION NUMBER

TITLE

AUTHORS

SOURCE

ENTRY YEAR

INOEX TERMS
ACCESSION NUMBER TITLE

\section{AUTHORS}

SOURCE

ENTRY YEAR

INDEX TERMS
194948

MATER!ALS FOR LEAK-PROOFING NAVY OIL TANKERS (SUPPLEMENT)

MATHEWS C W: VIND H P

U S haval CIVIL ENG LaB ReP No

NCEL-TN-1252-S. 11 FP. JULY 1973: AD-765.568/1 1974

ACDITIVE: -CRUDE OIL: ENGLISH: -FLUID LOSS:

FOAM: FOAF:ED PLASTIC: FOAMING: FOAMING

AGENT: -LEAK: MAINTEHANCE: MARINE

TRANSPORTATION: MIXTURE: -PETROLEUM:

PIPELINING. SHIP + STORAGE: -PLASTIC;

- POLYRER: PUAPING: REMOVAL: REPAIR: SEAL:

- SEALING: -SHIP; STORAGE FACILITY: TANK: TANK BOTTOM: -TANKER; TRANSPORTATION; US NAVAL

CIVIL ENG LAB: *VEHICLE

194476

WATERFLOODING PROCESS

JONES $L W$

US 3.817.331. C 6/18/74,F 12/22/72; AMOCO

PRODUCTION CO

1974

- AOOITIVE: ALCCHOL: ALIPHATIC: AMOCO

PRODUCTION CO: CHEMICAL: COMPOSITION:

COMPOUND: CRUDE OIL: DATA: -EFFICIENCY:

CEMENT COATED PIFE: CHART: COAL TAR: - COATING MATERIAL: - CCATING PROCESS: - CONSTRUCTION: CONTROL: CORROSION CONTROL: CRUDE OIL: DEPTH: DIAGRAM: ENGLISH: -EXTERNAL COATING: FOAM: FOAMED PLASTIC: FOAHING: INCONESIA:

INCOR:ESIAN SEAS: -INSULATING MATERIAL: JAVA: JAVA SEA: LINE PIPE: MARJUFACTURING:

MECHANICAL JACK: MIXTURE: OFFSHCRE: OFFSHORE EOUIFMENT: OIL AND GAS FIELOS: OIL FIELD:

FETROLEUM: PIFE: PIPELAYING BARGE: -PIPELINE: - PIPELINE CONSTRUCTION: PIPELINING. SHIP STORAGE: PIPING SYSTEM: PLASTIC: POLYMER: POLYURETHANE: FREFABRICATION: PROCEDURE: SEAS AND OCEANS: SHIP: SOLID HYDROCARBON: SOUTHEAST ASIA: SYSTEM (ASSEMBLAGE): TAR: * THEFMal INSULATION: TUBULAR GOODS:

- UNDEFWATER PIPELINE: VEHICLE: WATER DEPTH:

WELDED PIPE: WELDING

187338

CHEMICAL FOAMING AND SENSITIZING OF WATER-BEARING EXPLOSIVES WITH HYDROGEN PEROXIDE

TOMIC E A

U S 3.790.415,C 2/5/74,F 8/18/70: OU PONT DE NEMOURS \& CO

1974

ACRYLAMIDE: ACRYLAMIDE COPOLYMER: ACRYLAMIDE HCHCPOLYMER: - ADEITIVE: AMMONIUM NITRATE:

BLASTING: CHEMICAL: - COLLOIDAL DISPERSION:

COMPOSITION: COMPOUND: CONCENTRATION: DATA:

DU PONT DE NEMOURS \& CO: ENGLISH: -EXPLOSIVE: -FOAN: FOAMING: FOAMING AGENT: FUEL: FUEL

OIL: GEL: GELLING AGENT: HEATING FUEL: HYOROGEN PEROXIDE: INCRGANIC: *LIQUID

EXPLOSIVE: MIXTURE: NITRATE: ORGANIC:

OXIDIZING AGENT: PATENT (A): PEROXIDE:

POLYMIER: PROCEDURE: SENSITIVITY: -SENSITIZER:

TABLE (DATA): TEMPERATURE: THICKENER: WATER:

WELL COMPL SERV + WORKOVER: (P) USA 
ACCESSION NUMBER

TITLE

AUTHORS

SOURCE

ENTRY YEAR

INOEX TERMS

ACCESSION NUMBER

TITLE

AUTHORS

SOURCE

ENTRY YEAR

INDEX TERHS

ACCESSION NUMBER

TITLE

AUTHORS

SOURCE

ENTRY YEAR

INOEX TERAS
ACCESSION NUMBER

TITLE

AUTHORS

SOURCE

ENTAY YEAR

INDEX TERMS
167317

LOST CIRCULATION CONTROL

MESSENGER I U

U S 3.788.406.C 1/29/74.F 12/27/71: MOBIL

OIL CORP

1974

-ADDITIVE: -ASPHALT: BRIDGE PLUGGING:

- BRIDGING MATERIAL: CHEMICAL: *OAL:

COMPOSITION: COMPOUND; CONCENTRATION; DATA:

DISPERSANT: DISPERSING: DRILLING FLUID:

185052

CE::E:TT SPACER FLUIO

CARNEY L L

SPE OF AIME FCRMATION DAMAGE MTG PREPRINT NO

SPE.4784. PP 151-164, 1974

1974

CERENT: CERIENT SLURAY: - CEMENTING:

CIRCULATING: COH:PATIBILITY: OISPLACEMENT:

ORILLING FLUID: EMULSION: EMULSION MUD:

ENGLISH: FIELD TESTING: FLUSHING: FORMATION

OANAGE: MALLIEURTCN SERVICES: MIXTURE: OIL

QASE AUD: TESTING: WELL COMPL SERV +

WORKOVER: WELL COMPLETION: WWLL COMPLETION

FLUID

165006

DRILLING FLUID FILTRATION UNDER SIMULATED

DOWNHOLE CONDITIONS

SIMPSON $J$ P

SPE OF AIME FOR:RATION DAMAGE MTG PREPRINT NO

SPE-4779. FP $103 \cdot 116,1974$

1974

CHANGE: CLAY SHELLING: COMPOSITION: DATA:

- DRILLING FLUID: ORILLING FLUID TESTING:

DRILLING (WELL): ORILLING (WELL) (C):

ENGLISH: EXPANSION: EXPERIMENTAL DATA:

FILTRATE: FILTRATION: FLUID LOSS: FLUID

PROPERTY: FORHATION DAMAGE: HIGH PRESSURE:

HIGH TEMPERATURE: - INVADEO ZONE: - LABORATCRY

ECUIPMENT: LABCRATORY TESTING: MUD

CCAPOSITION: - MUD FILTER PRESS: MUD FILTRATE:

MUD PROPERTY: OIL BASE MUD: PHYSICAL

PROPERTY: - PHYSICAL SEPARATION: PRESSURE:

PROOUCTIVITY: ROTARY DRILLING: TEMPERATURE:

- TESTING: WATER BASE MUD

184559

RETHOD OF REMOVING LIOUIOS AND SMALL SOLIDS

FROM WELL BORES

GROVES $L$ L JR

U S 3.773,110,C 11/20/73, F 8/14/72:

CONTINENTAL OIL CO

1974

ACOITIVE; -AIR DRILLING: ALKALI METAL: ANION:

- ARTIFICIAL LIFT: CHEMICAL: CHEMICAL

INJECTION: CLEANING: CONTINENTAL OIL CO:

CONTROL: CUTTINGS REMOVAL: DRILLING FLUID:

- ORILLING (WELL): DRILLING (WELL) (C):

DRYING: ELEMENT (CHEMICAL): ENGLISH: FOAM

DRILLING: -FOAM LIFTING: FOAMING: FOAMING 
- DETERIORATION: -ORILLING FLUID: DRILLING FLUID SYSTEM: DRILLING (WELL): ENGLISH: FLOW PRCPERTY: GELATION: -HIGH TEMPERATURE: MILCHEM INC: NIIXTURE: MUD AOOITIVE: MUD COAPOSITIOH: PULO SYSTEM: ORGANIC ACID: PATENT: PHASE BEHAVIOR: PHASE CHANGE: PHYSICAL PROPERTY: POLYMER: REMOVAL: ROTARY DRILLING: SALT; STABILITY: SYSTEM (ASSEMBLAGE): TEMIPERATURE; THERMAL STABILITY: "THIXOTROPY: VISCOSITY: WATER BASE MUD: (P) USA

ACCESSION NUMBER TITLE AUTHORS SOURCE

ENTRY YEAR INDEX TERWS

ACCESSION NUMBER TITLE

\section{AUTHORS}

SOURCE

\section{ENTRY YEAR}

INDEX TERMS
ACCESSION NUMBER TITLE AUTHORS SOURCE ENTRY YEAR INDEX TERMS
182258

FOAM FOR SECONDARY AND TERTIARY RECOVERY GOGARTY $W$

U S 3.759.325, C 9/18/73, F 6/24/71: MARATHON OIL CO

1973

ADOITIVE: CHEM!ICAL INJECTION: CONTROL:

EFFICIENCY: - EMULSION FLOODING: ENGLISH:

FLOODING (FORMATION): FOAM: FOAM FLOODING:

FOAMING: FOAPING AGENT: IN SITU: INJECTION:

MARATHON OIL CO: MICELLE: MISCIBLE

DISPLACEMENT: MIXTURE: MOBILITY: MOBILITY

RATIO: OIL RECOVERY: PARTICLE: PATENT:

RECOVERY: RECOVERY MECHANISM: RESERVOIR ENG * REC NETHOD: "SECONDARY RECOVERY: SOLUBLE OIL: SURFACE ACTIVE AGENT: SWEEP EFFICIENCY:

-TERTIARY RECOVERY: WATER DRIVE (MISCIBLE): WATERFLOOD CONTROL: (P) USA

182197

HERE'S HOW OIL MUDS PERFORM AT HIGH

TEMPERATURES

BAUMANN R: METHVEN N E

PETROL PETROCHEM INT V 13, NO 9, PP 54.56. 61. SEPT 1973

1973

CIRCULATING SYSTEM: CIRCULATING TEMPERATURE: CONTROL: CORROSION: CORROSION CONTROL: DOEEP ORILLING: DENSITY: ORILL PIPE CORROSION: DRILLING FLUID: -DRILLING FLUID HYORAULICS: DRILLING FLUIO SYSTEM: DRILLING (WELL): ENGLISH; FLOW PROPERTY: FLUID PROPERTY: FORCE: HIGH TEMPERATURE: HYORAULICS: MECHANICAL PROPERTY: -MUD PROPERTY: MUD SYSTEM: MUO VISCOSITY: MUD WEIGHT: "OIL BASE MUD: FHYSICAL PROPERTY: RHEOLOGY: SHEAR: STABILITY: STRESS: SYSTEM (ASSEMBLAGE): TEMPERATURE: THERMAL STABILITY; VISCOSITY: YIELD POINT

172154 WEST TEXAS WCRKOVERS WITH FOAM GAIN FAVOR BLEAKLEY W B OIL GAS J V 71, NO 11. PP 97-98, 3/12/73 1973 ADOITIVE: ARTIFICIAL LIFT: CLEANING: DEEP PROOUCING: DRILLING (WELL): ECONOMIC FACTOR: ENGLISH: FOAM ORILLING: FOAM LIFTING: FOAMING: FOLMING $\triangle G E N T$ : FORMATION DAMAGE: GAS WELL: HOT WATER: LOSS: LOST CIRCULATION: - LON FRESSURE: NENS: PARAFFIN REKOVAL: PRESSURE: PRODUCING: REMOVAL: SAND REMOVAL: STAB!LIZATICN: SLCCESS RATIO: WELL: WELL CLEANOUT: WELL COMPL SERV + WORKOVER: WWELL WORKOVER 
ACCESSION NUMBER

TITLE

AUTHORS

SOURCE

ENTRY YEAR

INDEX TERHS

ACCESSION NUABER TITLE

AUTHORS

SOURCE

ENTRY YEAR

INDEX TERMS

ACCESSION NUMBER TITLE

\section{AUTHORS \\ SOURCE}

ENTRY YEAR

IHOEX TERMS
171712

CHEMICAL FOANIING OF WATER-BEARING EXPLOSIVES TOMIC E A

U S 3.711.345.C 1/16/73,F 8/18/70: OU PONT DE NEMOURS \& CO

1973

$\triangle$ DOITIVE: ARA:ONIUA NITRATE: RLASTING:

GLENDING: BOFCHYORIOE: COLLOIDAL DISPERSION:

CCMPCSITION: DU FONT DE NEMOURS \& CO:

EMULSICN: ENGLISH: EXPLOSIVE: FOAMING:

- FOAMIING aGENT: FUel: FUe: OIL: Gas

GENERATOR: GEL: GEOLOGY: GUAR GUM: HEATING

FUEL: MIXING: MIXTURE: NATURAL RESIN:

NITRATE: PATENT: -SENSITIZER: SLURRY: SODIUM BOROHYORIDE: SUSPENSION: - THICKENER: WATER THICKENING: WATER TREATING; WELL COMPL SERV WORKOVER: (P) USA

171668

OIL PHASE DRILLING flUID adoITIVE.

CCMPOSITION AND PROCESS

BROWNING W C: CHESSER B G; WOOD J L

US 3.709.819, C 1/9/73. F 5/14/71: MILCHEM

INC

1973

ABSORBENT: ACRYLIC ACID COPOLYMER: ADDITIVE:

ASPHALT: CIRCULATING SYSTEM: COMPOSITION:

CONTROL: DEEP DRILLING: DEPOSIT FORMATION:

- ORILLING FLUID: DRILLING FLUID SYSTEM:

ORILLING (WELL): ENULSION: EMULSION MUD:

ENGLISH: FILTER CAKE: FILTRATION: -FLUID LOSS ADOITIVE: GEOLOGY: HIGH PRESSURE: HIGH

TEMPERATURE: -INVERTED EMULSION MUD: MILCHEM

INC: MIXTURE; "MUD ADOITIVE: "MUD

167870

AOUECUS FOAMED VIELL CIRCULATION FLUIOS

CONTAINING A EASE CCMPONENT AND THEIR USE IN

THE TREATMENT OF WELLS

ANCERSON G W: HUTCHISON S O: MEKINNELL JC

CAN 913.891. C $11 / 7 / 72$. F 5/26/70. PR US

7/7/69: CHEVRCN RESEARCH CO

1972

ACID: $A C I O I Z I N G:$ AOOITIVE: BASE (CHEMICAL):

CHEMICAL: CHEVRON RESEARCH CO: CIRCULATING SYSTEM: CLEANING: COMPOUNO: ENGLISH: FOAM: FOAIHING : FOAHIING AGENT: MIXTURE :

- NEUTRALIZER: PATENT: SYSTEM (ASSEMBLAGE):

- Well CLEANOUT WELl COMPL SERV + WORKOVER:

WELL COMPLETION: WELL COMPLETION FLUID: WELL STIMULATION: (P) CANADA

167848

ACCESSION NUMBER

TITLE

AUTHORS

SUURCE

ENTRY YEAR

INDEX TERMS
COAPOSITIOAS FOR CONTROLLING FOAM IN AOUEOUS SYSTEA:S ANO ITS METHOD OF USE

LIESERMAN H

U S $3.697,442$, C 10/10/72, 8/13/70: BETZ

LABORATORIES INC

1972

ADOITIVE: ALKALINE EARTH RETAL: ALURINUM

OXIOE: -ANTIFOAPING AGENT: BETZ LAEORATORIES

INC: CARRIER: CHEMICAL: DRILLING FLUID:

DRILLIHG (WELL): EMULSION: ENGLISH: FATTY

ACID: HYDROXIDE: LIFOPHILIC: MIXTURE:

- MULTICOMPONENT MIXTURE: ORGANIC: PARTICLE:

PATENT: PHYSICAL PROPERTY: ROTARY DRILLING:

SILICA: "SURFACE ACTIVE AGENT; SURFACE

PROPERTY: "WATER BASE MUD: WETTABILITY: (P)

USA 
ACCESSION NUMBER TITLE

\section{AUTHORS \\ SOURCE}

ENTRY YEAR

INDEX TERMS
ACCESSION NUMBER

TITLE

SOURCE

ENTRY YEAR

INOEX TERMS
ACCESSION NUMBER

TITLE

AUTHORS

SOURCE

ENTRY YEAR

INOEX TERMS
ACCESSION NUMBER

TITLE

\section{AUTHORS}

SOURCE

ENTRY YEAR

INDEX TERMS
167847

DEFOAMER CCMPOSITIONS CONTAINING ORGANIC

PARTICLES

LICHTMAN I A: WOODWARD F E

U 53.697 .440 . C 10/10/72. F 6/27/69; DIALDND SHANIFOCK CORP

1972

ADDITIVE: AMIDE: -ANTIFOAMING AGENT:

CHEMICAL: CCMPOUND: DEFOAMING: DEGASSING:

DIAMOND SHATAROCK CORP: DRILLING FLUID:

CRILLING (WELL): ENGLISH: FOAM: HYDROCARBON COMPOUND: MIXTURE: MULTICOMPONENT MIXTURE:

OIL SOLUBILITY: ORGANIC: *PARTICLE: PATENT:

PHYSICAL PROPERTY: PHYSICAL SEPARATION:

- POLYAER: ROTARY DRILLING: SILICONE: *SOLIO: USA

166340

REMOVING OIL FROS: WATER

GR ERIT 1.291 .649 , C $10 / 4 / 7 \overline{2}, F 2 / 20 / 70$, PR

US 3/6/69: TEXACO DEVELOPMENT CORP

1972

ADSOREENT: $\triangle D S O R F T I O N$ : CLEANING: COALESCING: CORBUSTION: CONTAMINATION: CRUDE OIL:

ENGLISH: FLOATING: FOAM: FOAMED PLASTIC:

FOAMING: MIXTURE: OOIL WASTE: PATENT:

PETROLEUH: FHYSICAL SEPARATION: PLASTIC:

POLYMER: -REIHOVAL: SORBENT: SORPTION: SPILL: STYRENE; SUPPLEMENTAL TECHNOLOGY: TEXACO DEVELOPMENT CORP: WATER POLLUTION; (P) GREAT BRITA IN

166023

MICROSCOPIC BEHAVIOR OF FOAM IN POROUS MEOIA

MAST $R F$

47TH ANNU SPE OF AIME FALL MTG PREPRINT NO

SPE-3997. 12 PP. 1972

1972

ADDITIVE: ANALYTICAL METHOD: BUBBLE: CHANGE: COMPOSITION: CONCENTRATION: DATA: DETERGENT:

DFAIHAGE: ENCLISH: EXPERIMENT: FLOODING (FORMATION): FLUID FLOW: FOAM: FOAM FLOODING: FOAMING: FOAMING AGENT: - FORHATION PLUGGING: "GAS FLOW: INCREASE: INSTRUMENT: INTERFACE: "JAHIN EFFECT: LABORATORY DATA: MICROSCOPE: MICROSCOPY: MIXTURE: MODEL: MULTIFHASE FLOW: OPTICAL INSTRUMENT: PHASE BEHAVIOR: PHYSICAL PROPERTY: PLUGGING: POROUS AHEI A: RECOVERY: RESERVOIR ENG + REC METHOD: - RESERVOIR FLUID FLOW: STABILITY: SURFACE ACTIVE AGENT: TESTING: WELL PLUGGING

165985

FACTORS AFFECTING FOAM CIRCULATION IN OIL WELLS

BEYER A H: HASKIN C A: MILLHONE R S

47TH ANNU SPE OF AIME FALL MTG PREPRINT NO SPE-4001, 12 PP. 1972

1972

ADDITIVE: ARTIFICIAL LIFT: CARRYING CAPACITY: CIRCULATING: CIRCULATING SYSTEM: CLEANING: COMPUTER: COMPUTER PROGRAMING: CUTTINGS REMOVAL: DESIGN CRITERIA: DIGITAL COMPUTER: DRILLING (WELL): ENGLISH: FLOW PROPERTY: 
FLUIO FLCW: FOLA: -FOAM DRILLING: - FOAM LIFTING: FCA:HING: FOAMING AGENT: INUECTION PRESSURE: hIATHEMATICAL ANALYSIS:

- MathematICAL MODEl: mathematICS: MIXTURE: MODEL: PARAHETER: PHYSICAL PROPERTY:

PRESSURE: PRCGRAMING: REROVAL: SPECIFICATION: SURFACE ACTIVE AGENT: SYSTEM (ASSEMBLAGE): -Well CleanOUT: Well COMPL SERV + WORKOVER: WELL COMPLETION: WELL PRESSURE: WELL WORKOVER

ACCESSION NUMEER TITLE

\section{AUTHORS} SOURCE

ENTRY YEAR INDEX TERMS

ACCESSION NUMBER

TITLE

AUTHORS

SOURCE

ENTRY YEAR

INDEX TERMS

ACCESSION NUMBER TITLE

\section{AUTHORS}

SOURCE

ENTRY YEAR INOEX TERMS
165984

FLOW BEHAVIOF OF FOAM AS a WELL CIRCULATING FLUIO

BEYER A H: FCOTE R W: MILLHONE R S

$\triangle 7 T H$ ANNU SPE OF AIAIE FALL MTG PREPRINT NO

SPE-3986. 12 PP. 1972

1972

ADDITIVE: AFTIFICIAL LIFT: CIRCULATING:

- CIRCULATING SYSTEM: CLEANING: DRILLING

(WELL): ENGLISH: EOUATION: *FIELD TESTING:

FLOODING (FOA:AATICN): FLUID FLOW: -FLUID FLOW

EOUATION: FOLM: FOAH ORILLING: FOAM FLOODING:

- FOAMi LIFTING: FOAMING: FOAMING AGENT:

LABORATORY SCALE: MATHEMATICAL MODEL:

MATHEMATICS: MIXTURE: MODEL: MULTIPHASE FLOW:

RECOVERY: RE:HOVAL: RHEOLOGY: SAND REMOVAL:

- STEADY STATE FLOW: SURFACE ACTIVE AGENT:

SYSTEM (ASSE:ALLACE): TESTING: VERTICAL FLOW:

WELL CLEANOUT: WELL COMPL SERV + WORKOVER:

WELL WORKOVER

\section{3}

APPARATUS FOR FORMING FOAM FOR USE IN WELLS

CAMPEELL A E

U S 3,685,807,C 8/22/72, F 12/3/69: CHEVRON

RESEARCH CO

1972

ADDITIVE: ARTIFICIAL LIFT: CHEMICAL

INJECTION: CHEVRON RESEARCH CO: CIRCULATING:

- CIRCULATING SYSTEM: COHPOSITION: DRILLING

(WELL): ENGLISH: FLOODING (FORMATION): FLUIO

FLOW: FOAM: FOAM DRILLING: FOAM FLOODING:

FOAM LIFTING: "FOAMING: - FOAMING AGENT:

GENERATOR: INUECTION: MIXER: MIXING: MIXTURE:

PATENT: PHYSICAL PROPERTY: RECOVERY:

SOLUTION: STABILITY: SYSTEM (ASSEMBLAGE):

- TURBULENT FLOW: WELL COMPL SERV + WORKOVER:

WELL STIMULATION: (P) USA

161366

EXPLOSIVE-PROOF AATHOD ANO INCINERATOR FOR BURNING DRILL CUTTINGS

GRIFFIN P II:: PHILLIPS W $C$

U S 3.658.015, C 4/25/72, F 4/15/70: DRESSER INDUSTRIES INC

1972

CHEMICAL: CCHBUSTION: COHPOUND:

CONTABINATION: CRUDE OIL: CUTTINGS (ROCK):

OISPOSAL: DRESSER INOUSTRIES INC: DRILLING

FLUIO: DRILLING (WELL): EMULSION MUD:

ENGLISH: EXPLOSION:- FIRE HAZARD: HAZARD:

HYDRCCAREOR: CCPIPOUND: OFFSHORE DRILLING: OIL BLSE RILD: PATENT: PETROLEUM: PREVENTION:

REMIOVAL: ROCK SAHPLE: ROTARY DRILLING: SAFETY

EOUIPIIENT: SLMPLE: SUBSURFACE: UNDERWATER:

- Waste DISFOSAL: WATER POLlUTion: (P) USA 
ACCESSION NUMBER

TITLE

AUTHORS

SOURCE

ENTRY YEAR

INOEX TERMS

ACCESSION NUMBER

TITLE

\section{AUTHORS \\ SOURCE}

ENTRY YEAR

INDEX TERMS
ACCESSION NUMBER TITLE

AUTHORS
SOURCE
ENTRY YEAR
INOEX TERMS

161201

DENSITY OF ADSOREED WATER AT PLASTIC LIMIT

DOHENY E J: FUAGAROLI \& A

J SOIL MECH FOUND DIV $\triangle M E R$ SOC CIVIL ENG PROC

$\checkmark$ 98. NO SA:5. FP 523-529. MAY 1972

1972

ACCURACY: - ADSORPTION: BLOCK OIAGRAM:

CAPILLARITY: CAPILLARY FHENOMENON: CHART:

CLAY hIINERAL: CONPAAISON: COMPOSITJON: DATA:

- DENSITY: DETERISINING: DIAGRAM: DRILLING

FLUID: DRILLING (HELL): ENGLISH: EOUATION:

EXPERIMENTAL CATA: - FLUID PROPERTY: GRAPH:

LABORATORY TESTING: MATHEMATICS: MECHANICAL

PROPERTY: MINERAL: MOISTURE:

- MONTMORILLONITE: MUD PROPERTY: PHYSICAL

PROPERTY: PLASTICITY: PRESSURE: SILICATE MINERAL: SOIL (EARTH): SORPTION: SURFACE PROPERTY: TEMPERATURE: TESTING: WATER: WATER BASE MUD: "WATER CONTENT

160833

STABLE FOAM USED AS A CIRCULATING MEDIA IN WELLWORK PROCESSES

POOL F M

I9TH ANNU SW PETROL SHORT COURSE ASS MTG PROC PP 25-30. 1972

1972

ADOITIVE: ARTIFICIAL LIFT: -CIRCULATING:

CLEANING: CONTROL: CORING: COST: DRILLING

(WELL): ECONOHIC FACTOR: ENGLISH: FISHING

(WELL): FOAM: FOAM DRILLING: POAM LIFTING:

FOAMING: FOAHING $\triangle G E N T$ : FORMATION DAMAGE:

GEOLOCIC STRUCTURE: HIGH PRESSURE: MIXTURE:

OFFSHCRE WELL: PERFORMANCE: PHYSICAL

PROPERTY: PCPOSITY: PORCSITY (ROCK):

PRESSURE: PRODUCTIVITY INDEX: REMOVAL:

RESERVOIR: SAFETY: SAND CONTROL: -SAND

REMOVAL: STABILITY: STABILIZER (ADDITIVE):

THIEF FORMATION: WELL: WELL CLEANOUT: WELL CCMPL SERV + WORKOVER: WELL COMPLETION: WELL PERFORMANCE: WELL SERVICING: WELL WORKOVER: - WORKOVER FLUID

160799

PRE-FGRHED STABLE FOAM: THE NEW APPROACH TO BIG HOLE DRILLING AND SLIM-HOLE HIGH-PRESSURE CLEATOUTS

ANCERSON G W: HUTCHISON $S O$

I9TH ANNU SW PETROL SHORT COURSE ASS MTG PROC PP 9.18. 1972

1972

AODITIVE: ARTIFICIAL LIFT: ELOHOUT (WELL):

CHART: CLEANING: CLIMATE: CONTAMINATION:

COST: DATA: -DRILLING COST: -ORILLING FLUIO:

DRILLING RATE: DRILLING (WELL): ECONOMIC

FACTOR: ENGLISH: -FOAM: -FOAM DRILLING: FOAM

LIFTING: FOR:AATION DAMAGE: FORMATION

(GEOLOGY): GRAPH: LARGE HOLE DRILLING: LOW

PRESSLRE: LUBRICATOR (WELL): METEOROLOGICAL

PHENC:RENON: MIXTURE: PERFORMANCE : PERHAFROST:

PHYSICAL PROFERTY: PRESSURE: PRODUCTIVITY

INDEX: RATE: SAFETY: SEAL: STABILITY:

STABILIZER (ADDITIVE): STANDARD OIL CO

CALIFORNIA: TABLE (DATA): WATER POLLUTION:

WELL CLEANOUT: WELL COMPLETION; *WELL

COMPLETION FLUID: WELL PERFORMANCE: WELL

SERVICING: WELL WORKOVER: WORKOVER FLUID 
ACCESSION NUMBER TITLE

AUTHORS

SOURCE

ENTRY YEAR

INDEX TERMS

ACCESSION NUMBER TITLE

LUTHORS

SOURCE

ENTRY YEAR

INDEX TERMS

ACCESSION NUMEER

TITLE

AUTHORS

SOURCE

ENTRY YEAR

INDEX TERAS

ACCESSION NUMBER TITLE

¿UTHORS

SOURCE

ENTRY YEAR

INDEX TERMS
160625

PROCESS FOR MAINTAINING THERMAL CONDUCTIVITY OF INSULATICI IN PERMAFROST COMPLETION

BLOLNT E $M$

U 53.642 .065 . C 2/15/72, F 7/23/70: MOBIL

OIL CORP

1972

ADDITIVE: ANNULUS: ARCTIC AREA: CASING

SETTING: CLIMATE: ENGLISH: FOAM: FOAMING:

FOANING AGENT: -GAS INJECTION: INJECTION:

INSULATING MATERIAL: METEOROLOGICAL

PHENOA:ENON: MIXTURE: MOBIL OIL CORP: PATENT:

- PERMIAFROST: PHYSICAL PROPERTY: SEAL:

SEALING: -THERHAL CONDUCTIVITY: -THERMAL

INSULATION: THERIHAL PROPERTY: THERMOOYNAMIC

SITU: -INCOHFETENT BEO: INJECTION: LOSS:

- Lost CIRCULATICH: MIXING: MIXTURE: PATENT:

PLASTIC: PLUGGING: POLYMER: POLYMERIZATION:

RESERVOIR: SAND CONSOLICATION: SAND CONTROL:

SETTIH.G TIME: SLOUGHING SHALE: -THIEF

FOR:IATION: TIHE: NELL PLUGGING: (P) USA

158896

STABILIZATION OF HARD SHALY FORMATIONS WITH

aLKaLI NETAL SILICATE

DARLEY H C H

U S 3.640.343. C 2/8/72. F 5/20/70: SHELL OIL CO

1972

ADOITIVE: ACHESIVE: ALKALI METAL: BOND

STRENGTH: CONTRCL: DRILLING FLUID; DRILLING

PROBLEM: DRILLING (WELL): ENGLISH: HOLE

CAVING: HOLE STABILIZATION: INCOMPETENT BED:

MECHANICAL PRIFERTY: MECHANICAL STRENGTH:

PATENT: PHYSICAL PROPERTY: ROTARY DRILLING:

- SHALE CONTROL: SHELL OIL CO: SILICATE:

- SLOUGHING SHALE: STABILITY: STABILIZATION:

- STABILIZER (ADOITIVE): "water base muD: (P)

USA

158573

LIFTIIUS FOAMING CRUDE BY L VARIABLE RPM

SUBHERSIBLE PUMP

DRAKE E L: VINCENT R P

CAN 893.526,C 2/22/72,F 2/27/70, PR US

4/17/69: aHOCO CANAOA PETROLEUM CO SEe REL

PAT ABSTRM 144.652

1972

AMOCO CANADA PETROLEUM CO: CORG WARNER CORP:

ENGLISH: PATENT: (P) CANADA

158510

THE EFFECT OF MINERAL OIL ON THE SURFACE

PROPERTIES OF BINARY SURFACTANT SYSTEMS

GODOARD E D: PRINCEN H M

$\checkmark$ COLLOID INTERFACE SCIV 38, NO 2, PP

523.534. FEB 1972

1972

ADDITIVE: ALCOHOL: CHEMICAL: COMPOUND: CRUDE

OIL: DODECYL ALCOHOL: ELUTION: ENGLISH:

EXTRACT: FILM: FOAM: FOAMING: -FOAMING AGENT:

MIXTURE: PETROLEUM: PHYSICAL PROPERTY:

PHYSICAL SEFARATION: RESERVOIR ENG + REC

METHOD: SODIUM DODECYL SULFATE: STAEILITY: 
ACCESSION NUMAER

TITLE

AUTHORS

SOURCE

ENTRY YEAR

INDEX TERMS
ACCESSION NUMBER TITLE

AUTHORS

SOURCE

ENTRY YEAR

INDEX TERMS
ACCESSION NUMBER

TITLE

AUTHORS

SOURCE

ENTRY YEAR

INDEX TERMS
156949

WELL-CE!HENT!HC HETHCO USING A SPACER

CORIFCSITIO:

PLRKEER F $N$

U S 3.625.226. C 12/7/71. F 6/1/70: ATLANTIC RICHFIELD CO

1972

ACIO: ATLAITIC RICHFIELO CO: BORATE: CASING

SETTING: CEIENT: - CEMENT SLURRY: "CEMENTING:

CEMENTING EQUIPRENT: CHEMICAL: COMPOUND:

ORILLING FLUID: EHULSION: ENGLISH: HALIDE: HYCPCXIDE: MIXTURE: OIL BASE MUD: CRGANIC ACIO: PATENT: -SEPARATOR (PLUG): SULFATE: * WATER IN OIL EMULSION: WELL COMPL SERV + WORKOVER: WELL COMPLETION FLUID: (P) USA

156929

CHARTS HELP FIND VOLUME. PRESSURE NEEDED FOR FOAH DR!LLING

KRUG J A: MITCHELL $B$ J

OIL GAS J V 70, NO 6, PP 61-64, 2/7/72

1972

ACOIT,VE: AFTIFICIAL LIFT: CHART: -CUTTINGS

REHOV :L: CIFFERE:TIIAL EOUATION: DRILLING

FLUIS. DR:LIING PROBLEH: DRILLING RATE:

DRILL;NG (VIELL): ENGLISH: EQUATION: FLUID:

FLLID FLOW: FOAIA: FOAL DRILLING: FOAM

LIFTING: FCAHING: FOAMING AGENT: GRAPH: HOLE CAVING: - IR.COHPETENT BED: MATHEMATICAL

ANALYSIS: RATHEMLTICAL RODEL: MATHEMATICS:

MIXTUFE: MSOEL: PIEWTONIAN FLUID: NONNEWTONIAN

FLUID: NUI:ERICAL ANALYSIS: PHYSICAL PROPERTY:

PRESSLFE: FATE: REMOVAL: : SLOUGHING SHALE:

STABILITY: SUGSURFACE FRESSURE: WELL

PRESSURE: WELL SERVICING: WELL WORKOVER:

WORKOVER FLUIO

156791

WATER CLARIFIER ANO SEPARATOR

WATERMAN L C

U 5 3.623.608, C $11 / 30 / 71$. F 2/20/70, PR US

$10 / 31 / 68$

1972

- Calide desalting: ofying: english: floating:

FOAHING: GAS INUECTICN: INJECTION; LEASE

EOUIFRENT: MECHANICAL DEHYDRATION: OIL

PRODUCING; OIL TREATING (FIELO): OIL WATER

SEPARATION: OIL WATER SEPARATOR: PATENT:

PHYSICAL SEPARATION: PRODUCING: PRODUCING OIL

+ GAS: SEPARATION EQUIPMENT: WASTE MATERIAL:

METHOO: ROCK; SANOSTONE: SEDIMENTARY ROCK:

- SEPARATION EQUIPHENT: *TAR SAND: -TAR SANo

OIL: -TAR SAND OIL RECOVERY: VISCOUS OIL

RECOVERY: WATER: (P) CANADA

156477

METMCD OF GAS CRILLING

MUCKLEROY J A

CAN 8SO.822. C 1/18/72, F B/1/58. PR US

5/8/58: $A M O C O$ CANADA PETROLEUM CO

1972

LDDITIVE: ARGCO CANADA PETROLEUM CO:

ARTIFICIAL LIFT: CHEHICAL INUECTION:

CIRCULATING: - CUTTINGS REMOVAL: DRILLING

RATE: DRILLING (WELL): ENGLISH: *FOAM 
DRILLING: -FOLM LIFTING: FOAMING: -FOAMING AGENT: GAS DRILLING: IMPROVEMENT: INJECTION: MIXING: PATENT: RATE: RENOVAL: *WATER ENTRY: (P) CANADA

ACCESSION NUMBER

TITLE

AUTHORS

SOURCE

ENTRY YEAR

INOEX TERMS
ACCESSION NUMBER

TITLE

AUTHORS

SOURCE

ENTRY YEAR

INDEX TERMS
ACCESSION NUMBER

TITLE

AUTHORS

SOURCE

ENTRY YEAR

INOEX TERMS
156365

RECOVERY OF BITUMEN FROM TAR SAND

CLARK L

CAN 889.284,C 12/28/71, F 1/22/68; CITIES

SERV ATHASASCA INC. ATLANTIC RICHFIELD CO. IMPERIAL OIL

1972

AERATION: ATLANTIC RICHFIELD CO: BITUMINOUS

DEPOSIT: AITUMINOUS SANDSTONE: CITIES SERV

ATHABASCA INC: CRUDE OIL: DEASPHALTING:

DEPOSIT (GEOLOGY): ENGLISH: FOAM: FOAMING:

IMPERIAL OIL LTD: MIXING; MIXTURE: OIL

RECOVERY: PATENT: PETROLEUM:- PHYSICAL

SEPARATION: RECOVERY: REMOVAL: RESERVOIR ENG

+ REC METHOD: ROCK: ROYALITE OIL CO LTD:

SANDSTONE: SEDIMENTARY ROCK: SOLID: TIAR

SAND: -TAR SAND OIL: -TAR SAND OIL RECOVERY:

(P) CANADA

\section{1}

METMOD FOR DRILLING IN PERMAFROST

BONE L: ELLARD J D

U S 3.618.680. C 11/9/71, F 5/15/70: ATLANTIC RICHFIELD CO

1972

AODITIVE: - ARCTIC DRILLING: ASBESTOS:

ATLANTIC RICHFIELD CO: CLIMATE: CONTROL:

- ORILLING FLUID: DRILLING (WELL): EMULSION

MUD: ENGLISH; FERROMAGNESIAN MINERAL;

ENGLISH: EXPANSION: FILTRATE: FLUID FLOW:

FLUIO LOSS: FLUID PROPERTY; FOFMATION DANAGE:

GaS FlOW: GAS RESERVOIR: GAS WELL: -GAS WELL

CAPAC:TY: GEOLOG:C STRUCTURE: - INVADED ZONE:

INVERTED EMULSIOAV MUD: MUD FILTRATE: MUD

PRCGRAH: PAUD PROPERTY: PERFCRMANCE:

PERMEABILITY: PERMEABILITY (ROCK): PHLSE

BEHAVIOR: PHASE DIAGRAM: PHYSICAL PROPERTY:

PRODUCING CAPACITY: PRODUCTIVITY: PROGRAM:

RELATIVE PERHEABILITY: RESERVOIR: RESERVOIR

FLUIO FLOW: ROCK PROPERTY: WATER BASE MUD:

- WATER BLOCK: WELL: *WELL PERFORMANCE

152479

APPLICATIONS OF STABLE FOAN IN CANADA

CHRISTENSEN R. J: CONNON R K: MILLHONE R $S$

OILWEEK V 22. NO 31. PP 30, 32-35, 67. 9/20/71

1971

ADDITIVE: ARTIFICIAL LIFT: CANADA: CHEVRON

STANDARD LTD: CLIMATE: DENSITY: DISPOSAL:

- ORILLING FLUIO: ORILLING PROBLEM: DRILLING

(WELL): ENGLISH: FLUID FLOW: FLUID PROPERTY:

FLUIO VELOCITY: FOAH: FOAM CRILLING: * FOAM

LIFTING: FOAMING: FOAMING AGENT: - FORMATION

DAMAGE: HOLE CAVING: HUSKY OTL CANADA TTO:

- LOW PRESSURE: METEOROLOGICAL PHENONENON:

MIXTURE: NEWS: PERFOFMANCE: PERMAFROST:

PMYSICAL PROPERTY: PFESSURE: RESERVOIR

PRESSURE: STABILITY: SURFACE ACTIVE AGENT:

VELOCITY: WASTE DISPOSAL: WELL WORKOVER 
ACCESSION NUMEER

TITLE

AUTHORS

SOURCE

ENTRY YEAR

INDEX TERMS

ACCESSION NUMEER

TITLE

AUTHORS

SOURCE

ENTRY YEAR

INDEX TERMS
ACCESSION NUMBER

TITLE

AUTHORS

SOURCE

ENTRY YEAR

INDEX TERMS

\section{ACCESSION NUMEER}

\section{TITLE}

\section{AUTHORS \\ SOURCE}

ENTRY YEAR

INDEX TERMS
152473

DEEP MISSISSIPPI DRILLING PRACTICES

KIRK W L

46TH ANNU SPE OF AIME FALL MTG PREPRINT NO

SPE-3510. 12 PP. 1971

1971

ANTICLINE: BASIN: BIT PERFORHANCE; BIT TYPE;

BIT (FOCK): BLOWOUT PREVENTER: CASING

SETTING: "CASING STRING DESIGN: CENENT:

- CEMENTING: CONTROL EOUIPIAENT: CORROSION:

- DEEP DRILLING: DEEP WELL: DESIGN; OIAHOND

BIT; DOME: DRILL STEM: DRILLING EQUIPMENT:

DRILLING FLUID: DRILLING PROGRAM: DRILLING

(WELL): EARTH AGE: ENGINEERING: ENGLISH: FOLO

(GEOLCGY): GAS WELL: GEOLOGIC STRUĆTURE:

GEOLOCY: HIGH PRESSURE: HYDROGEN SULFIDE

CORROSION: JURASSIC: MESOZOIC: MISSISSIPPI:

MISSISSIPPI SALT BASIN: *MUD PROGRAM: NATURAL

GAS: OIL BASE MUD: PERFORMANCE: PETROLEUM:

PRESSURE: PRESSURE CONTROLLER: PROGRAM;

151385

STABLE FOAIA CIRCULATICN CUTS SURFACE HOLE COSTS

ANDERSON G W

WORLD OIL V 173. NO 4. PP 39-42. SEPT 1971

1971

ADOITIVE: - $\triangle R C T I C$ DRILLING: ARTIFICIAL LIFT:

CANACA: CASE HISTORY: CASING (WELLI:

CAVITATION: CHART: CLIMATE: COST: DATA:

- ORILLING COST: ORILLING FLUID: - DRILLING

RATE: DRILLING (WELL): EAGLE PLAIN AREA:

ECONOAIC FACTOR: ENGLISH: EXPLORATORY

DRILLING: FLUID FLOW: FOAM: POAM DRILLING:

- FOARI lIFTING: FOAMING LGENT: GRAPH:

METECROLOGICAL PHENONEACN: MIXTURE: NEWS:

PERI:AFROST: RATE: SHALLOW WELL: STAFDARO OIL CO CALIFORNIA: SURFACE CASING: TABLE (DATA): TUGULAA GOOOS: WELL: YUKON

151376

NEAR-GAUGE HOLES THRCUGH PERMAFROST

ANDEPSON $G W$

OIL GIS J V 69. NO 38, FP 128, 130, 132, 134.

136, 139, 141-142, 9/20/71

1971

- ARCTIC DRILLING: BIT DIAMETER: BIT TYPE:

-BIT KEAR: BIT (ROCK): CANAOA: CASING

SETTING: CASING (WELL): COMPARISON: COST:

DIAIIETER: -ORILLING COST: DRILLING EQUIPMENT:

DRILLING FLUIJ: - DRILLING RATE: DRILLING

(WELL): ECONCHAIC FACTCR: ENGLISH: FOAPA: FOAM

DRILLING: HOLE DIAIRETER (WELL): MIXTURE:

NEWS: PHYSICAL PROPERTY: RATE: STAEILITY:

STABILIZATION: STANDARD OIL CO CALIFORNIA:

SURFACE CASING: TUBULAR GOODS; WATER BASE

MUD: WEAR: YUKON

151210

AFPARATUS FOR MAKING PREFORMED FOAM FOR USE

IN WELLS

HUTCHISON 50

U S 3.593.800, C 7/20/71, F 8/25/69: CHEYRON

RESEARCH - CO

1971

ADDITIVE: ARTIFICIAL LIFT: CHEVRON FESEARCH

CO: CIRCULATING: CLEANING: ENGLISH: FOAM: 
FOAM LIFTING: FOAMING: -FOAMING AGENT:

GENERATOR: MIXTURE: PATENT: WWLL CLEANOUT:

WELL COMPL SERV + WORKOVER: WELL COMPLETION:

WELL COMPLETION FLUID: WELL WORKOVER;

- workover fLUio: (P) USA

ACCESSION NUMBER TITLE

AUTHORS
SOURCE

ENTRY YEAR

INOEX TERMS
ACCESSION NUMBER

TITLE

SOURCE

ENTRY YEAR

INDEX TERMS

ACCESSION NUMBER TITLE

AUTHORS

SOURCE

ENTRY YEAR

INDEX TERMS
151168

WELL DRILLING METHOD USING DECANOL IN PLACE

OF. OIL IN ACUEOUS DRILLING FLUIDS

ESTES $J C$ : PARK A

U $53.594 .317, C 7 / 20 / 71$. F 11/12/69; PAN

AMERICAN PETR CORP

1971

ADOITIVE: ALCOHOL: CHEMICAL: CLAY MIUD:

COMPOSITION: COMPOUND: DECYL ALCOHOL:

DRILLING FLUID: DRILLIA.G (WELL): ENGLISH:

FLOW PROPERTY: FLUID PFOPERTY: FRICTION: -MUO

ADOITIVE: -RUU CON:POSITION: MUD PROFERTY: MUO

VISCOSITY: OIL BASE MUO: PAN AREERICAN PETR

CCRP: PATENT: PHYSICAL PROPERTY: PIPE

STICKING: ROTARY ORILLING: SKIN FRICTION:

VISCOSITY: "WATER BASE RHD: (P) USA

150950

FOAMING AGENT CONCENTRATE

GR BRIT 1,248.358,C 9/29/71,F 4/7/70, PR US 4/7/69: CHEVRON RESEARCH CO SEE REL PAT ABSTR N. 144.600

1971

CHEVRON RESEARCH CO: EI:GLISH: PATENT: (P)

GREAT ERITAIN

150648

TEST DATA FILL THEORY GAP ON USING FOAM AS A

DRILLING FLUID

MITCHELL $B$ J

OIL GAS JVE9. NO 36. PP 96-100, 9/6/71

1971

ADOITIVE: ARTIFICIAL LIFT: BUEELE: EUBBLE

FLOW: CHART; CUTTINGS REMOVAL: DATA:

-ORILLING FLUID: ORILLING (WELL); ECONOMIC

FACTOR: ENILISH: EXPERIAENTAL DATA: FILM:

FLOW PROPERTY: FLUID FLC'N: -FOAHA: -FOAM

OR!LLING; FG:i: LIFTING: FOAIIING LGENT: GRAFH:

- HYORCCYNAIIIC THECRY: INTERFACE: LAHINAR

FLCW: MATHEMAT:CLL ANALYSIS: MATHEMIATICS:

IIXTURE: PERFCR::ILNCE: PHYSICAL PROPERTY:

OUALITY: REMOVAL: RHEOLOGY: STATISTICAL

ANALYSIS: - SUCCESS RATIO: SLRFACE ACTIVE

AGENT: TABLE (DATA): THEORY: THIN FILM:

VISCOSITY

BEHAVIOR: PHYSICAL PROPERTY: -POROUS MEDIA:

PRESSLRE GRADIENT: RECOVERY: -RELATIVE

PEFIEABILITY: RESERVOIR ENG + REC METHOD:

-RESERVOIR FLUID FLOW: STAEILIZATION:

STAEILIZER (AODITIVE): STEAOY STATE FLOW:

SURFACE: - SURFACE ACTIVE AGENT: SURFACE

PROPERTY: SURFACE TENSION: THESIS: UNSTEADY

STATE FLOW 
ACCESSION NUMBER

TITLE

\section{AUTHORS \\ SOURCE}

ENTRY YEAR

INDEX TERMS
ACCESSION NUMBER

TITLE

AUTHORS

SOURCE

ENTRY YEAR

INOEX TERMS
ACCESSION NUMBER

TITLE

AUTHORS

SOURCE

ENTRY YEAR

INDEX TERMS
150002

FOA:A A:OS ORILLII:G IN IRAN'S ZAGROS MOUNTAIN AFEA

GARAVINI O: RADENTI G: SALA A

OIL GAS J $V$ 69. NO 33. PP 82.84, 89.90. $8 / 16 / 71$

1971

ADDITIVE: COIPARISON: COMPOSITION: CORROSION: COST: DRILL PIPE CORROSION: ORILLING FLUID: DRILLING FRCELEM: - ORILLING RATE: ORILLING

(WELL): ECCNOHIC FACTOR: ENGLISH: FOAM: FOAM DRILLING: FOAMIING: FOAMIING AGENT: HAZARD: -hole caving: -hole stabilization: hyDRogen SULFIDE: IRAN: LOSS: - LOST CIRCULATION;

MIXTURE: NEWS: PERSONNEL: RATE:

STABILIZATION: SULFIDE: ZAGROS MT

149795

GAS-LIOUID SCRUBBING TOWER

HARDISON L C

U S 3.585.786. C 6/22/71. F 8/12/68:

UNIVERSAL OIL PRODUCTS CO

1971

ABSOREER:' $\triangle E S O R P T$ ION: $\triangle B S O R P T I O N$ PROCESS:

CLEAIUING: COLUHN: ENGLISH: FLUID: FOAMING:

-GAS DEHYDRATION: GAS PROCESSING:

INHIBITION: LIQUID: MASS TRANSFER: PATENT:

PHYSICAL SEPARATION: -PRODUCING EOUIPMENT:

PRODUCING OIL + GAS: *PURIFYING: REMOVAL;

SEPARATION EOUIPNENT: SOLIO: SORPTION:

SORPTION PROCESS: UNIVERSAL OIL PRODUCTS CO:

(P) USA

FORMATION DABAGE: - FORMATION EVALUATION:

FFACTURED RESERVOIR: GEOLOGIC STRUCTURE:

INTERPRETATION: - INVADED ZONE: MUD ADOITIVE:

MUD FILTRATE: NEUTRON CAPTURE: *NEUTRON

LOCG!NG: NUCLEAR LOGGING: NUCLEAR REACTION:

PERA:EABILITY: PEFHEASILITY (ROCK): PHYSICAL

PROPERTY: POROSITY: POROSITY (ROCK):

PRODLCING CAPACITY: RESERVOIR: RESERVOIR

CHARACTERISTIC: RESERVOIR FLUID: ROCK

PROPERTY: SALT CONTENT: SALT WATER MUD:

SATURATICN: SONIC LOGGING: VUGGY POROSITY:

WATER EASE MUD: WATER SATURATION: - WELL LOG

INTERPRETATION: WELL LOGGING: WELL LOGGING + SURVEYING

145919

THE RHEOLOGY OF FOAM

MARSDEN S S JR

14TH ANNU ACS PETROL RES FUND REP RES $P 92$.

1970

1971

ADDITIVE: BUEBLE: COMPFESSIBILITY: ENGLISH:

FLOOOING (FORMIATICN): FLOW PROPERTY: FLUID:

FLUID FLOW: FLUID PROPERTY: FOAM: FOAM

FLOOOING: FOANING: FOAIAING LGENT: GEL

STRENGTH: MATHEMATICAL ANALYSIS: MATHEMATICS:

MECHANICAL PROFERTY: MIXTURE: MULTIPHASE

FLOW: NONNEWTONIAN FLUID: FARTICLE SIZE:

PHYSICAL PROPERTY: POROUS MEDIA: RECOVERY:

RESERVOIR ENG + REC METHOD: RESERVOIR FLUIO

FLOW: "RHEOLOGY: SLIP VELOCITY: TUBE: TUBULAR

GOODS: VELOCITY: VISCOSITY 
ACCESSION NUMBER

TITLE

AUTHORS

SOURCE

ENTRY YEAR

INDEX TERMS

ACCESSION NUMBER

TITLE

AUTHORS

SOURCE

ENTRY YEAR

INDEX TERMS
ACCESSION NUMBER

$$
\text { TITLE }
$$

\section{AUTHORS \\ SOURCE}

\section{ENTRY YEAR}

INDEX TERMS
ACCESSION NUMBER

TITLE

AUTHORS

SOURCE

ENTRY YEAR

INDEX TERMS
145918

THE PHEOLOGY OF FOAM

MARSOEN S S JR

13TH LNNU ACS PETROL RES FUND REP RES P 92.

1969

1971

BUSBLE: BUSINESS OFERATION: COMPRESSIBILITY: DISTRICUTICN: EMULSION: EPAULSION FLOODING:

ENGLISH: EXPERIIAENT: FLOODING (FORMATION)

FLOW FFOPERTY: FLUID: FLUIO FLOW: "FLUIO

PROPERTY: FOAM: FOAM FLOODING: FOAMING: GEL

STRENGTH: MATHEMATICAL ANALYSIS: MATHEMATICS: MECHANICAL PROPERTY: MIXTURE: NONNEWTONIAN

FLUID: PARTICLE SIZE: PHYSICAL PROPERTY:

POROUS NEOIA: RECOVEFY: RESEARCH: RESERVOIR ENG + REC METHOD: RESERVOIR FLUID FLOW:

- RHEOLOGY: SLIP VELOCITY: STABILITY: TESTING:

TUBE: TUBULAR GOODS: VELOCITY: VISCOSITY

145845

USES OF AIR \& GAS IN FOTARY ORILLING

PUGH J B

CAN FEIROL $V$ 12. NO 4. PP 22-23. APRIL 1971

1971

ADD:TIVE: AERATEO MUD: -AIR DRILLING:

ARTIF!CIAL LIFT: BIT LIFE: BUSINESS

OPERATION: CANADA: CASING SETTING: CASING

STRII:G DESIGN: CEMENTING: CONTROL: CORROSION

CONTROL: CORROSION INHIEITOR: COST: DESIGN:

-DRILLING COST: DRILLIHG FLUID: DRILLING

PRCELEM: CRILLING RATE: DRILLING (WELL):

ECOHCHIC FLCTOR: ENGIIIEERING: ENGLISH:

EVALUATION: FOAM LIFTING: FOAMING AGENT:

FORMATION DAMAGE: FORMATION EVALUATION: *GAS

DRILLING: INHIBITCR: LIFE SPAN: -MIST

ORILLING: FATE: ROTARY DRILLING: USA: WELL COMPLETION COST

\section{4}

ATTAPULGITE CLAYS FOR FUTURE INDUSTRIAL MINERAL MARKETS

HAAS C Y

CENTEN ANNU SHE OF AI:AE MTG PREPRINT NO

$71 \cdot H-54,14$ FP, 1971

1971

ADDITIVE: $A R E A:$-ATTAPULGITE: CLAY MINERAL:

- clar mud: "colloidal dispersion:

COMPOSITION: CRYSTALLIZATION: DRILLING FLUID:

DRILLING (WELL): ENGLISH: FLOW PROPERTY;

GELLING AGENT: MINERAL: MIXTURE: MUD

SALIEITY: MUD VISCOSITY: PHASE EEHAVIOR:

PHASE CHANGE: FHYSICAL PROPERTY: ROTARY

DRILLING: SALT CONTENT: "SALT WATER MUD:

SILICATE MINERAL: SOLIDIFICATION: STABILITY:

SURFACE AREA: THICKENER: THIXOTROPY:

VISCOSITY; WATER BASE MUD: WELL WORKOVER:

-WORKOVER FLUID

144940

OIL WELL DRILLING ANO TREATING FLUIDS

BETTY R J: MARSH B E: MARSH F $S$

CAN 868.817. C $4 / 20 / 71, F 6 / 20 / 68$, PR US

6/30/67: $\triangle R M O U R$ INOUSTRIAL CHEH CO

1971

AODITIVE: AMINE: ARMOUR INOUSTRIAL CHEH CO:

CHEMICAL: CHEMICAL REACTION: COMPOUND:

- DRILLING FLUID: ORILLING (WELL): ENGLISH:

- FRACTURING FLUID: GELLING AGENT:

-HYDROCARBON COMPOUNO: ISOCYANATE RESIN: OOIL 
ACCESSION NUMEER TITLE

\section{AUTHOFS \\ SOURCE}

ENTRY YEAR

INDEX TERA:S
ACCESSION NUMEER

TITLE

AUTHORS

SOURCE

\section{ENTRY YEAR}

INDEX TERHS

ACCESSION NUMBER

\section{TITLE}

AUTHORS

SOURCE

ENTRY YEAR

INDEX TERMS
144099

EFFEET CF ORGANIC ADOITIVES ON IMPREGNATEO

CIAHOND ORILLING

SCHULTZ C W: SELIM A A: STREBIG K C

$U$ S EUR MINES REP INVEST NO 7494. 35 PP. N:ARCH 1971

1971

AOOITIVE: BIT COST: BIT LIFE: - BIT

PERFORMLNCE: BIT WEAR: EIT WEIGHT: BIT

(ROCK): BUSINESS CPERATION: CHEMICAL:

CCHPARISON TEST: CCRPOSITION: COST: DATA:

- DIANOND BIT: - DIAMONO DRILLING: DRILL STEM

TOROUE: DRILLING COST: DRILLING FLUID:

DRILLING RATE: -ORILLING RESEARCH: DRILLING

(WELL): ECONOHIC FACTCR: ENGLISH: ETHYLENE

GLYCOL: EXPERIMENTAL CATA: FORCE; FRICTION:

GLYCEROL: GLYCOL: INSTRUHENTATION- LABORATORY

ECUIPMENT: LABORATORY SCALE: LIFE SPAN:

MATHEMATICAL ANALYSIS: MATHEMATICS: MINERAL;

- MUD ADOITIVE: MUD COMPOSITION: ORGANIC:

OXIDE MINERAL: PERFORHANCE: OUARTZ: RATE:

RESEARCH: ROTARY ORILLING: ROTARY SPEED:

STAT:STICAL ANALYSIS: STRESS: SURFACE ACTIVE AGENT: TESTING: TORQUS: WATER: WATER EASE

MUD: WEAR: WEIGHT

144092

USES OF AIR \& GAS IN ROTARY DR!LLING

PUGH J $E$

9TH ANNU ONTARIO PETROL INST INC CONF PROC

PAPER NO 10,6 PP. i970

1971

AERATEO MUD: :AIF ORILLING: ARCTIC ORILLING:

BIT LIFE: CLIMATE: CORROSION: COST: DRILL

PIPE CORROSION: DRILLING COST: DRILLING

FLUID: DRILLING IN: ORILLING PROGRAM:

DRILLING RATE: DRILLING (WELL): ECONOMIC

FACTOR: ENGLISH: -FOA:A DRILLING: FORMATION

DANAGE: - GAS DRILLING: HYDROSTATIC PRESSURE:

LIFE SPAN: LOSS: LOST CIRCULATION:

METEOROLOGICAL PHENOMENON: MIST DRILLING:

PERMAFROST: PERMAFROST ZONE: PLUGGING:

PRESSURE: PROGRAM: RATE: -ROTARY DRILLING:

WATER ENTRY: WATER SHUTOFF: WELL COMPLETION

COST: WELL PLUGGING

141975

DRILLING FLUID ACOITIVES

STRATTON $C$ A

U 53.558 .487 . C $1 / 26 / 71$. F 12/31/63:

PHILLIPS PETKOLEUHA CO

1971

ADOITIVE: CORPOSITION: ORILLING FLUID;

DRILLING (WELL): ENGL ISH: FLOW PROPERTY:

FLUID PRCPERTY: MUD ADDITIVE: MUD

COHPCSITION: NUD PROPERTY: MUO PUMPABILITY:

- "UD THINNER: "PUD VISCOSITY: NAFHTHOL:

PATENT: PHENCL: PHILlifS PETROLEUM CO:

PHYSICAL PROPERTY: PUMPABILITY: OUINONE:

RHEOLOGY: SULFONATE: VISCOSITY: "WATER BASE

MUD: (P) UNITED STATES 
ACCESSION NUMBER

TITLE

AUTHORS

SOURCE

ENTRY YEAR

INDEX TERMS

ACCESSION NUMBER

TITLE

AUTHORS

SOURCE

ENTRY YEAR

INDEX TERMS

ACCESSION NUMBER

TITLE

AUTHORS

SOURCE

ENTRY YEAR

INDEX TERMS
141363

VISCOSITY OF FOAB

MITCHELL $8 J$

OKLAHCAA UH:IV PHD THESIS. 155 PP. 1970

1971

ARTIFICIAL LIFT: CHART: - CUTTINGS REMOVAL:

DRILLING (WELL): ENGLISH: FLOW PROPERTY: FOAIA: FOAM DRILLING: FOAM LIFTING: FOAMING: FORCE: MIXTURE: PHYSICIL PROPERTY: REMOVAL: SHEAR: STRESS: -SURFACE ACTIVITY: SURFACE PROPERTY: THESIS: 'VISCCSITY

\section{7}

RECOVERY OF HEAVY METALS FROM BITUMINOUS SANOS BOWHAN C W

CAN 861.580. C 1/19/71.F 10/7/68. PR US

12/27/67: CITIES SERV ATHABASCA INC. IMPERIAL

OIL LTO.

1971

ATLANTIC RICHFIELO CO: - EITUMINOUS CEPOSIT:

BITU:MINOUS SANDSTONE: CITIES SERV ATHABASCA

INC: DEPOSIT (GEOLOGY): ENGLISH: "FLOTATICN:

FOAM: FOANIING: GRAVITATIONAL SEPARATION:

- HEAVY MINERAL: IMPERIAL OIL LTD: METAL:

MINERAL: MIXTURE: PATENT: PHYSICAL

SEPARATION: -RECOVERY: REMOVAL: RESERVOIR ENG

+ REC METHOD: ROCK: ROYALITE OIL CO LTO:

SANDSTONE: SEDIHENTARY ROCK: TAR SAND: (P)

\section{CANADA}

140702

SUFFLCE MUD SYSTEISS. PT. 2. UNWEIGHTED RUDS - ADD!TIONS AND REMOVALS

BOBO R

OIL GAS JV 69, NO 5, FP $78.81,84.87,2 / 1 / 71$ 1971

AOOITIVE: EENTCNITE: CARBOXYMETHYL CELLULOSE:

CENTRIFUGE: CIRCULATING EQUIFI:ENT:

CIRCULATING SYSTEH: CLAY; COAL: COLLOIDAL

DISPERSION: CCHPOSITION: CYCLCNE SEPARATOR:

DENSITY: DEPOSIT (GEOLOGY): CRILLING FLUID:

DRILLING FLUIO SYSTEM; DRILLING RATE:

DRILLING (WELLI: ENCLISH: FILTER CAKE: FLCW

PROPCETY: FLUID LOSS ADCITIVE: FLUID

PROFERTY: GAS SEPARATOR: GEL STRENGTH:

LIGNIN: LIGNITE; LIGNOSULFONATE: MIXTURE:

- MUO ADOITIVE: MUUO CENTRIFUGE: MUD

COMPOSITION: MUD CYCLCNE: RUD DEGASSER: MUD

DESANCER: MUD DESANDING: MUO PIT: MUD

PROPERTY: MUD SEPARATOR: -MUO SYSTEM: $M U D$

TREATING: MUD VISCOSITY: MUD WEIGHT: NATURAL

RESIN: PHOSPHATE: PHYSICAL PROPERTY: PHYSICAL

SEPARATION: OUEBRACHO: RATE: ROTARY DRILLING:

SEPARATION EOUIPI:ENT: SHALE SHAKER: STARCH:

STORAGE FACILITY: STORAGE PIT: SYSTEM

(ASSER:BLAGE): VISCOSITY: WATER BASE MUD:

WATER CONTENT: WEIGHTING MATERIAL

\section{5}

FREFOFHED STASILIZED FOAM

HILLMAN M

DRILL BIT V 17. NO 10. PP 12:13, 16-17. JAN

1971

1971

ADOITIVE: APFLICATION: ARTIFICIAL LIFT:

CARRY ING CAPACITY: - CIRCULATING: CLEANING: 
ACCESSION NUMBER

TITLE

AUTHORS

SOURCE

\section{ENTRY YEAR}

INDEX TERMS

CO::PATIEILITY: COST: DENSITY: DRILLING FLUID: ORILLING (WELL): ECONOHIC FACTOR: ENGLISH: FLOW FROPERTY: FLUIO LOSS: FLUID PROPERTY: - FOAA: FOAM DRILLING: FCAM LIFTING: FOAMING AGENT: FORMATION DAMAGE: LOW FLUID LOSS: MIXTURE: PHYSICAL PROPERTY: STABILITY: VISCOSITY: WELL CLEANCUT: WELL COMPL SERV WORKOVER: WELL COMPLETION FLUID: WELL WORKOVER: "WORKOVER FLUID

INTERFOLATION: MATHEMATICAL ANALYSIS:

MATHEA:ATICS: METER: - RUUD VISCOSITY: OIL BASE

MUC: FHYSICAL FROPERTY: PROCEOURE: -REFERENCE DATL:: : RHEOLOGY: TE:PPERATURE: TEMFSRATURE COWE.NSATION: VISCO:OETER; VISCOSITY: WATER BASE R:UD

\section{0}

INCPEASING FOAM STABILITY IN EARTH FORMATIONS DALEEN D L: RAZA S H

U S 3.530.940. C $9 / 29 / 70$. F 2/5/69. PAN A:IERICAN PETR CORF 1970

ADCITIVE: ENGLISH: FOA:A: FOAMING: FOAMING AGENT: MIXTURE: PAN AMERICAN PETR CORP: PATENT: PHYSICAL FROPERTY: PLUGGING:

- PLUGGiNG aGENT: polymer: STABILITY: - STARILIZER (ADDITIVE): - TEMPORARY PLUGGING: VINYL ALCOHOL HOHOPOLYMER; WELL COMPL SERV + WORKCVER: WELL COAPLETICN: WELL PLUGGING: WELL KORKOVER: (P) UNITEO STATES:

2-PYRROLIOINONE

ACCESSION NUMBER

TITLE

AUTHORS

SOURCE

ENTRY YEAR

INDEX TERMS

\section{ACCESSION MUMBER}

TITLE

\section{AUTHORS}

SOURCE

ENTRY YEAR

INDEX TERMS

\section{5}

DRILLING FLUIO

KOLAIAN UH

U S 3.531.408, C 9/29/70, F 4/25/67, TEXACO

INC

1970

ADOITIVE: CARBOXYNAPHTHALENE, DIHYDR:

CHEMICAL: CCMPOUR:D: DERIVATIVE (CHEMI CAL): - OISFERSANT: DISFERSING: OISULFONAPHTHALENE. NITROS: DRILLING FLUID: DRILLING (WELL): ENGLISH; FLOW PROPERTY: FLUID PROPERTY: GEL: GEL STRENGTH: MIXTURE: "MUD ADOITIVE: "MUO PROPERTY: MUD VISCOSITY: NAPHTHALENE; PATENT: PHYSICAL PROPERTY: RHEOLOGY: ROTARY DRILLING: SALT: TEXACO INC: THIXOTROPY: VISCOSITY: - water base hud: (P) UNITEo states

135709

METHOD OF COATING TUBULAR OQJECTS WITH POLYURETHANE fOAM

STEWART S A

GR ERIT 1,207,110, C $9 / 30 / 70$, F $5 / 10 / 69$. MARTIN SWEETS CO INC

1970

CLEANING: COATING MATERIAL: - COATING PROCESS:

ENGLISH: EXTERNAL COATING: FILH: FLUID: FOAM: CPIVE: GAS ORIVE: -GAS OIL CONTACT: GAS RESERVOIR: GEOLCG:C STRLCTURE: INJECTION: INTERFACE: M:XTURE: OIL RECOVERY: OIL RESERVOIR: PATENT: RECOVERY: RECOVERY NECCHAHISH: RESERVOIR: RESERVOIR ENG + REC HETHOD: - SECONOARY RECOVERY: (P) CANADA 
COMPOSITION: DRILLING FLUIO: ENGLISH: GLASS: IN:TIAL STRENGTH: MECHANICAL PROPERTY: MECHAPICAL STFENGTH: MUD ADOITIVE: PATENT: PHYSICAL PROPERTY: SETT!NG TIME: -SILICA CEHENT: T:MIE: -WATER BASE MUD: WELL COMPL SERV \& WORKOVER: WELL COMPLETION: (P) USA

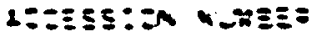 \\ $\because \because \div-E$ \\ AUTHORS \\ SOURCE \\ ENTRY YEAR \\ INOEX TERMS
}

ACCESSION NUMBER

TITLE

AUTHORS

SOURCE

ENTRY YEAR

INDEX TERAS
ACCESSION NUMBER TITLE

\section{AUTHORS}

SOURCE

ENTRY YEAR

INDEX TERMS

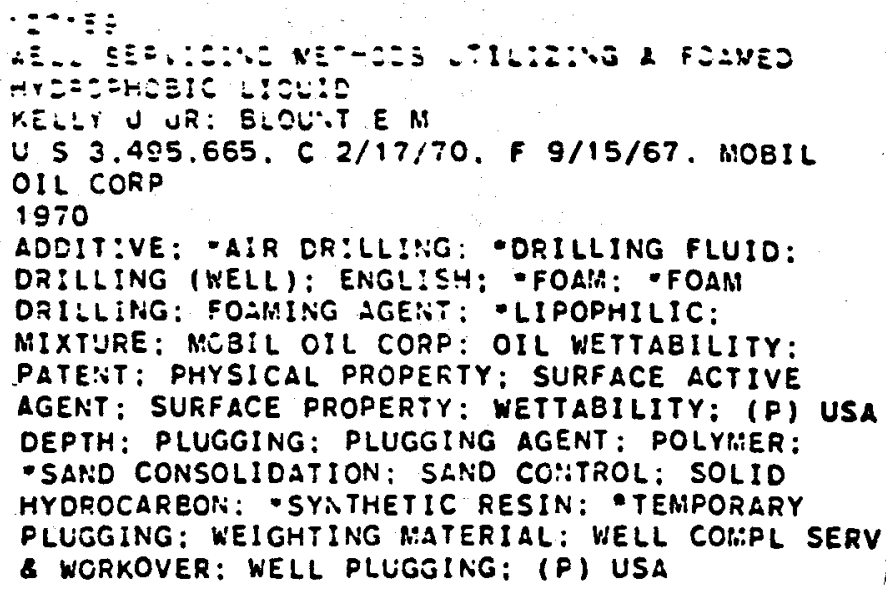

123923

a new way to cor:pute alinular frictlon loss

KOTE I K

J PETFOL TECHNOL V 22, PP 8-10. JAN 1970

1970

- anNular flch: circulating sySTEM:

COMPLRISON: COMPUTER: DATA: DERIVATIVE

(MATHEMATICS): DIGITAL COMPUTER: DRILLING

FLUID: DRILLING FLUID SYSTEM: ORILLING

(WELL): EMULSICN R:JO: ENGLISH: EOUATION: FLOW

PROPERTY: FLUID: -FLUID FLOW: FRACTLRING

FLUIC: FRICTICN LOSS (FLUID): FUNCTION

(MATHEMATICS): GEL: INVERTED E!IULSION R:UD:

LOSS: LOW SCLIDS NUD: MATHEMATICAL N.ODEL:

MATHEMATICS: HIXTURE: H:SOEL: MUD SYSTEM:

- NONNEWTONIAN FLUID: OIL BASE MUD: PHYSICAL PROPERTY: SALT WATER NILD: SYSTEM

(ASSEHBLAGE): TAELE (DETA): THIXOTROFY: WATER BASE HUD

123922

AMMOR.IATEO FOAREO WELL CIRCULATION FLUIDS ANO USES THEREOF

HUTCH!SCN S O, $\because$ OOERSR: $G W$ : MEKINNELL J C U S 3.426,560, C 12,30,69, F 4,12/68, CHEVRCN RESEARCH CO

1970

AOO:TIVE: AMHONI L: CARRYING CAPACITY: CHEVRON RESEARCH CO: CIRCULATI:IG: CLEANING: CUTTINGS REMOVIL: -ORILLIISG FLUIO: DFILLING (WELL): ENGLISH: FLOH PROPERTY: FOLII: -FOLI:

ORIL:DNG: FOA:IIHO AGENT: GAS DR:LLING:

MIXTLEE: FATENT: FHYS:CAL FROPERTY: FEMOVAL:

WELl CleaNOUT: (F) USA 
ACCESSION NUMBER TITLE

AUTHORS

SOURCE

ENTRY YEAR

INDEX: TERMS

ACCESSION NUMBER

TITLE

AUTHORS

SOURCE$$
\because:
$$

ENTRY YEAR

INOEX TERMS
ACCESSION NUMBER

TITLE

AUTHORS

SOURCE

ENTRY YEAR

INDEX TERMS
133988

FOL:R WORKOVERS ARE ALSO SUCCESSFUL IN THE

PER:AIAN BASIN AREA

N:! CHEL C C

WELL SERY V 10, NO 4. PP 17. 22, JULY-AUG 1970 1970

ART:FICIAL LIFT: CHANGE: CHEVROH RESEARCH CO: CIRCULATING: CIRCULATIAG PRESSURE:

CIRCULATING RATE: CLEANING: CONTRACT: CORING: CUTTINGS REMOVAL: DECREASE: ORILLING (WELL):

ECONOMIC FACTOR: ENGLISH: FOAM: FOAM

DRILLING: FOA:A LIFTING: FORAATION DARLGE:

LEGAL CLNSIDERATION: MIXTURE: NEW BEXICO:

NEWS: OIL PUCDUCING: PATENT: PPERIIIAN BASIN:

PRESSURE: PRESSLRE DECLINE: PFODUCING: RATE:

REHOVAL: SANO RERICVAL: -STRIPPER WELL; TEXAS:

WELL: WELL CLEANOUT: WELL COMPL SERV +

WORKOVER: WELL PRESSURE: WELL SERVICING:

- Well WORKOVER

133987

PREFORIMED STABILIZED FOAM

HILLHIAN $M$

WELL SERV V 10. NO 4. PP 13, 15, 18-19.

JULY-AUG 1970

1970

ADOITIVE: ARTIFICIAL LIFT: CEMENTING: CHEVRON

RESEARCH CO: CIRCULATIIIG PRESSURE:

CIRCULATING RATE: CIRCULATING SYSTEM:

CLEANING: CONTRACT: CON:TROL: CORING: COST:

CRUDE CIL: CUTTINGS REMOVAL: DENSITY:

DRILLING (WELL): ECONOMIC FACTOR:

EMULSIFICATION: ENGLISH: FLOW PROPERTY: FOAM:

FOAIA DRILLING: -FOAM LIFTING: FORMATION

DAN:AGE: INJECTION: LEGAL CONSIDERATION: LINER

CC:IFLETION: LCW: MIXTURE: PATENT:

PERFORMANCE: PETROLEUIA: PHYSICAL PROPERTY:

PIPE STICKING: PRESSURE: PRESSURE CONTROL:

PRODUCTION RATE: RATE:- REMOVAL: SAND REMOVAL:

STABILITY: STABILIZATION: STABILIZER

(ADDITIVE): STEAM INJECTION: SYSTEM

(ASSEMBLAGE): TEMPERATURE; VISCOSITY: VISCOUS CRUDE OIL: WELL CLEANOUT: WELL COMPL SERV +

WORKOVER: WELL COMPLETION: WELL COMPLETION

DFILLING FLUID SYSTEM: DRILLING (WELL):

ERIULSIFIER: ENGLISH: FLOCCULANT: FLOW

PRCFERTY: FLUIO LOSS AOCITIVE: FOAHING $\triangle$ LENT:

GAS DRILLING: INHIBITOR: ION EXCHANGE: LOST

CIREULATICN ADDITIVE: - LOW SOLIDS NUDD:

LUBRICATIC:: AIST OF!LLING: -MUD ADDITIVE:

- AUUC COMPOSITION: -MUD SYSTEM: MUD VISCOSITY:

- OIl Base MUD: PESTICIOE: PH: PHYSICAL

PROPERTY: REVIEW OR SURVEY: ROTLRY DRILLING:

SHALE CONTROL: SURFACE aCtIVE AGENT: SYSTEM (ASSEMIELAGE): TAELE (DATA): VISCOSITY: WATER BASE MLD: WEIGHTING MATERIAL

127194

METHOD ANO COMPOSITION FOR CEMENTING OIL WELL CASI:HG

WYLET R E: VAN DYKE 0

U S 3.499.491. C 3/10/70. F 6/28/68. ORESSER

INDUSTFIES INC

1970

ACOITIVE: - CASING SETTING: CEMENT: CEMENT

COMPOSITION: - CEREENT SLURRY: CEMENTING: 
ACCESSION NUMEER

TITLE

AUTHORS

SOURCE

ENTRY YEAR

INCEX TERMS

ACCESSION NUMBER

TITLE

AUTHORS

SOURCE

ENTRY YEAR

INDEX TERMS
ACCESSION NUMBER

TITLE

SOURCE

ENTRY YEAR

INDEX TERMS
ACCESSION NUAIBER

TITLE

AUTHORS

SOURCE

ENTRY YEAR

INDEX TERMS
123039

STIELE FOAIA PGYS CUT

RINTCUL $B$

CALIF OIL WCPLD \& E2, :0 22, Pi $1 \cdot 4,11 / 30 / 69$

1970

CODITIVE: ARTIF:CIAL LIFT: -CASE HISTORY:

CLEANING; DATA: CEFLECTOR; DIRECTIONAL

DRILLING: CRILE:SO (NELL): EAGLISH: FOAIA:

- FOAM LIFTING: FCAMIIHG AGENT: LINER

CCH:PLETION: HIXTURE: NEWS: PHYSICAL PROPERTY: STAEILITY: WWLL CLEAH:OUT: WELL COPPL SERV \& WCAKOVER: WELL COAPLET!CN: WELL SERVICING:

-WELL WORYCVER: VIHIPSTOCK: WORKOVER FLUID

\section{7}

OIL-FIELD APPLICATION OF DETERGENTS

HILLCRAN T

KENTUCKY GEOL SUPV SPEC PUBLICATION NO 15.

SER 10. PP 103-104. 1968

1970

AOCITIVE: $\triangle I R$ DRILLING: APPLICATICN:

ARTIFICIAL LIFT: CLEAIIING: DRILLING FLUID:

DRILLING (WELL): DRYIIHG: ENGLISH: FLUID:

- FOAiI DRILLING: FOAM LIFTING: FOAMING AGENT:

GAS VIELL DEWATERING: LIQUID: PETROLEUPA

INDUSTRY: PHYSICAL PROPERTY: SOLUBILITY:

-SURFACE ACTIVE AGENT: WATER SOLUBILITY:

-WELL CLEANOUT: WELL COMPL SERY \& WORKOVER

122751

STAELE FOAM CUTS COSTS. INCREASES PROCUCTION PETROL ENG $V 41$. NO 13, PP 61-63, DEC 1969 1970

ACID: AOOITIVE: AIR: AINNULAR FLOW: ARTIFICIAL LIFT: BASE (CHERIICAL): ERINE: CARBON DIOXIDE: CARRYING CAPACITY: CEMENT: CHEIIICAL: CHEVRON RESEARCH CO: CLEANING: COMPOUND: COST: CRUDE OIL: CENSITY: ECCNC:IIC FACTOR: ELENENT (CHEHICAL): ENGLISH: EXHAUST GAS: FLOW PROPERTY: FLUID FLON: FOAM: -FOAM LIFTING: -FOAMINNG AGENT: IMPURITY: INERT GAS: IRON OXIDE: IRON SULFIDE. FES: MIXING: MIXTURE: NEWS: NITROGEN: PETROLEUM; PHYSICAL PROPERTY: SODILIR HYCKOXIDE: STABILIZATION: STABILIZER (ADCITIVE): STANDARO OIL CO CALIFORNIA SURFACE ACTIVE AGENT: VELOCITY: VISCOSITY: VISCOUS CRUDE OIL: WASTE MATERIAL: WATER: -WELL CLEANCUT: WELL COMPL SERV \& WORKOVER: WELL SERVICING: WELL SERVICING COST: *WELL WORKOVER: WORKOVER FLUID

$120 \leqq 59$

FOAN WORKOVERS CUT COSTS 50 PERCENT HUTCHISON SO

HORLD OIL V 169. NO 6, PP 73-74, NOV 1969 1969

ADDITIVE: ARTIFICIAL LIFT: CIRCULATING:

CIEAI:ING: COST: DATI: DEEP WELL: ORILLING 
COST: DRILLING (V:ELL): ECONOHIC FACTOR:

EHGLISH: FOAH: -FOAN DRILLING: FOAM LIFTING: FOAIIING: FOAIAING AGENT: MAINTENANCE:

MAINTENANCE COST: MIXTURE: NEWS: PERFORMANCE: PHYSICAL FROPERTY: PRODUCTION STATISTICS:

STAEILITY: STAGILIZATICN: STABILIZER

(LDDITIVE): STANCAFD OIL CO CALIFORNIA:

STATISTICS (DATA): TABLE (OATA): WELL: WELL CLEANOUT: WELL CORPI SERV + WORKOVER: WWELL COMPLETION: WELL COMPLETION COST: WELL PERFORMANCE: -WELL SERVICING: WELL SERVICING COST: WELL SERVICING RIG: "WELL WORKOVER: - WORKOVER FLUID

\section{ACCESSION NUMBER TITLE SOURCE ENTRY YEAR INDEX TERMS}

ACCESSION NUMBER TITLE SOURCE ENTRY YEAR INDEX TERMS
ACCESSION NUMBER

TITLE

SOURCE

ENTRY YEAR

INOEX TERMS
ACCESSION NUMBER TITLE

\section{SOURCE}

ENTRY YEAR

INOEX TERMS
$120 \$ 5$,

WHAT OAM I: AND HOW IT'S USED

W:F. D OIL V 169. NO 6. PP 75.78, NOV 1969

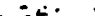

$\because:$ :VE: CIFCULATIHG: CIRCULATING SYSTEM:

$C_{L} \cdots$ iNG: ENGLISH: FOAHI: FOARING: FOAMING

AGENT: MIXINO: MIXTURE: NEWS: STABILIZATION:

STA3!LIZER (ADDITIVE): SYSTEM (ASSEMBLAGE):

-WELL CLEATOUT: WELL COMPL SERV + WORKOVER;

- WELL WORKOVER: "WORKOVER FLUID

\section{5}

HOW FOAM AIOS OIL RECOVERY

WORLD OIL V 169. NO 6. PP 90-91, 94, NOV 1969 1969

ADO!TIVE: ARTIFICIAL LIFT: BASE (CHEMICAL):

CHEMICAL: CHEHICAL INJECTION: CIRCULATING:

CLEANING: COHFOUND: ECONOMIC FACTOR: ENGLISH: FISHING (WELL): FOAH: - FOAM LIFTING: FOAMING: FOAHING AGENT: HYOROGEN SULFIDE: MIXTURE:

NEUTRALIZER: NEWS: FHYSICAL PROPERTY:

PROEUCTIVITY: PROFITABILITY: REMOVAL: SAND

REMCVAL: STASILIZATION: STABILIZER

(ADOITIVE): SULFIOE: WWLL CLEANOUT: WELL COMPL SERV + WORKOVER: "WELL SERVICING: 'WELL STIMULATION; -WELL WORKOVER

120952

STAELE foAN: SPEEDS Well Cleanout

WORLD OIL $\vee$ 159. NO 6. PP 78-82. NOV 1969 1969

ACOITIVE: $A R I I F I C I A L$ LIFT: BAILER: CASE HISTCRY: CIRCULAT!NO: CIRCULATING SYSTEM:

CLEANING: CC:PPARISON: DATA: ORILLING (WELL):

ENGLISH: FCA:: FOAR ORILLING: FOAM LIFTING:

FOLIIING: MIXTURE: NEINS: REMOVAL; -SAND

REMOVAL: STABILIZER (LDOITIVE): SYSTEM

(ASSE:IBLAGE): TAELE (OATA): - WELL CLEANOUT:

WELL CC:APL SERV + WORKOVER: WWLL SERVICING:

WELL SERVICING FIG: WELL WORKOVER

120946

STEAIH AND FOLM SIMPLIFY LINER RUNNING AND RETRIEVAL

KORLC OIL V 169, NO 6. PP 83.87. NOV 1969 1969

ADOITIVE: GUS INESS OFERATION: CLEANING: COHPARISON: COST: DATA: DRILLING CCST:

ORILLINC ECUIPAENT: CRILLING (HELL): ECONOHIC

FACTCR: NGLISH: FOLHA: FOAM ORILLING: 
GRAPHICAL REPRESENTATICN: INUECTION: LINER: - LINER COMPLETICN: LINER (WELL): MATHEMATICAL ANALYSIS: MIATHEYATIES: "IXTURE: NEKS: FEATOR!:ANCE: FHYSICAL FFOPERTY: PROCUCTIVITY: SALVAGING: SIAEILIZATICN: STABILIZER (AOOITIVE): - STEAM INUECTION: TABLE (DATA): - WELL CLEANOUT: WELL CSRPL SERV + WORKOVER; WELL COMPLETION: WELL CCMPLETION COST: WELL PERFormance: - Well SerVICING: -Well Servicing COST: -WELL WORKOVER

ACCESSION NUMBER

TITLE

AUTHORS

SOURCE

ENTRY YEAR

INDEX TERMS
ACCESSION NUMAER TITLE

AUTHORS

SOURCE

ENTRY YEAR

INDEX TERMS
ACCESSION NUMBER

TITLE

AUTHORS

SOURCE

ENTRY YEAR

INOEX TERMS
120448

DRILLING FLUIO

SAUBER C A: SHANNON J $L$

U S 3.471.402.C 10/7/69.F 7/25/66 PR US

4/26/63. PHILLIPS PETROLEUM CO

1969

ADDITIVE: ASEESTOS: CAREOXYMETHYL CELLULOSE:

COAPOSITION: CONTRACT: CONTROL: DRILLING

FLUID: - DRILLING FLUID CONTROL: DRILLING

(WELL): ECONOMIC FACTOR: EMULSION MUD:

ENGLISH: FERROHAGNESIAN MINERAL: FLOW

PROPERTY: FLUIO LOSS: FLUID LOSS ADOITIVE:

FLUID PROPERTY: FRESH WATER AHD: LEGAL

CONSIDERATION: LOW FLUID LOSS: MINERAL: "AND

AODITIVE: MUD COHPOSITION: MUD PROPERTY; 'MUD

TREATING: MUUD VISCOSITY: PATENT: PHILLIPS

- FLUTD LOSS ADOITIVE: FLUID PROPERTY: LEGAL

CONSIDERATION: LOW FLUID LOSS: - MUD ADOITIVE:

NUD FROPEFTY: OIL EASE MUD: PATENT: PHILLIPS

PETRCLEUM CO: PHYSICAL PROPERTY: POLY:AER:

POLYOXYETHYLENE: RHEOLOGY: WATER BASE NUD:

(P) USA

118307

COMPARISON OF THE EFFICIENCY OF THE RELOVVAL OF CAREON DIOXICE FRGI: A GAS BY WATER UNDER PRESSURE IN A PACKED TCWER. AND IN A TOWER

OPERATING UNDER

GREGOR AH: PALKA J: SVOLIAVA Hi

INT CHEM ENG V 9. NO 3. PP 4EO-485, JULY 1969 1969

ARMON!A: BASE (CHEMICAL): -CARBON DIOXIDE

REMOVAL: CARBON MONOXIDE; - CASE HISTORY:

CHEPIICAL: COLUIAN: COLLIIN FACKING: COMPARISON: CCHPOUND: CZECHOSLOVAKIA; OATA; EFFICIENCY:

ELEH:EH:T (CHEH:CAL): ENGLISH: FIXED EED: FOAM: FOAHI : L: GLS PRCCESSINS: - INCUSTRIAL PLANT:

MIXTUIE: MA:URAL GAS: NITROGEN: OOXIDATION

FEACT, ON: PITROLEUM: PRCDUCING OIL + GAS:

; : UE!!ER: SIPARATION EQUIPMENT: SOOIUM

i. C. IDE: .WATER SCRUBBING

$1: 8365$

FLCW GEOIMES OF STABLE FOAMS

HOFFEA M S: RUEIN E

IND ENG CHEM V 8. NO 3. PP 483-490.. AUG 1569

1.969

ADOITIVE: AIR DRILLINC: ARTIFICIAL LIFT:

- BUESLE FLCN: CHART: COLURN: CORRELATION:

DATA: DRILLING (WELL): ENGLISH: EXPERIBENTAL

DATA: FLCN PROPERTY: FLOW RATE: FLUID FLOW:

FLUIO VELCCITY: FOAIA: FOAM DRILLING: "FOAM 
LIFTING; FOAMING: FOAMING AGENT: GAS FLOW: - Gas OIL SEPARATION: -GAS OIL SEPARATOR: GAS PRODLCING: GAS SEPARATOR: GRAOIENT: GRAPH: INTERFICE: LITERATURE SEARCH: HASS TRANSFER: M:XTURE: HULTIPHASE FLCW; OIL PRODUCING: PHYSICAL PROPERTY: PHYSICAL SEPARATION: PLUG FLOW: PRESSLEE GRADIENT: PRCDUCING: PRODUCING OIL + GAS: PRODUCTION STATISTICS: RATE: REYNOLDS NUMBER: SEPARATION EQUIPMENT: SPRAYING: SURFACE ACTIVE AGENT: TURBULENT FLOW: VELOCITY: VERTICAL

GoODS

ACCESSION NUMBER TITLE AUTHORS SOURCE

ENTAY YEAR INDEX TERMS
ACCESSION NUMBER TITLE

\section{AUTHORS}

SOURCE

ENTRY YEAR INDEX TERMS
ACCESSION NUMEER

TITLE

AUTHORS

SOURCE

ENTRY YEAR

INDEX TERMS
101917

AIR DEILLING TO DATE

GILEERT T J: TUCKER B C

19TH ANN PETR SOC OF CIM C I $M+$ M TECH MTG $5 / 7 \cdot 10 / 63$ PREPRIAT NO 6835. 3 PP

1968

ADOITIVE: -AIR ORILLING: CHANGE: CONTROL:

CORFOSION: CORROSION CONTROL: CORROSION COST: CORPCSION RESISTANCE: CORROSIOII THEORY: CCST: COST CONTRDL: DEVELOF:AENT: DEVELOPAENT COST: DRILL FIPE CORROS:CIV: ORILLING COST: CRILLING ECUIF.IENT: ORILLING PFOSLEM: DRILLING PROGRAH: ORILLING RATE: ORILLIHG THEORY: DR ILLING (WELL): ECONCMIC FACTOR: ENGLISH: - FOLA: DRILLING: FOAMING AGENT: - GAS DRILLING: PASSIVITY: PLUGGING: PRCGRAM: - PROGRESS REFOFT: RATE: REPORT; THEORY: WATER SHUTOFF: WELL PLUGGING

101732

FATTY ALCOHOLS AS PERFOGMANCE BOOSTERS AND FOAI: STABILIZERS WITH FATTY ALCOHOL SULFATE SALTS

ARTHUR R P: CHOCOLA L R: SHORE A: SHORE $S$ US 3.394.768. C T/30/68. F 10/4/65 RICHARDSCN Co 1968 ADOIT!VE: -AIR DRILLING: ALCOHOL: CARBOH CONTENT: CHERIICAL: COMPOSITICN: COMPOUND: CONIRACT: CUTTINGS REMOVAL: -DRILLING FLUID: DRILLIING (W'ELL): ECONOHIC FACTOR: ENGLISH; -FOLM: FOAM DRILLING: -FOAMING AGENT: LEGAL COHSIDERATION: MIXTURE: MUD COMPOSITION: PATENT: REIHOVAL: RICHARESON CO: SALT: STABILIZER (ADDITIVE): SULFATE: (P) USA

100942

SURFACTANT COMFOSITION

ZIKA H T

US $3.391,750, C 7 / 9 / 68$, F 8/9/65 UNION

CARBIDE CORP

1968

AOOITIVE: -AIR ORILLING: ARTIFICIAL LIFT:

BRINE: CLEANING: COMPOSITICN: CONTRACT:

DRILLING (WELL): ECONOMIC FACTOR: ENGLISH:

FOAM ORILLING; *FOAM LIFTING: FOAMING:

- FOAMING aGENT: GAS DRILLING: GAS PRODUCING: 
Survey of Industry Authorities on Foam Drilling

A significant part of this study was to interview industry personnel on the use of foams in geothermal drilling. Initial contact was by letter, with a written questionnaire. These are included in this appendix. Because of poor written response, each of the people were contacted by phone. After discussion and assemilation of results, approximately fifteen following contacts were made to clarify points and expand information.

A cross-section of comments by persons contacted are included. It seems from the interviews that the more knowledgeable a person in geothermal drilling, the more optimistic they were on potential savings from the use of foams. 
Attached is a brief questionaire which I would appreciate you, or one of your people, giving me some help on. This questionaire will be used to guide me in a foam project sponsored by the Department of Energy through Sandia Labs. Hopefully your input will ultimateiy lead to advanced technology which will undoubtedly be useful to your company.

One of our initial efforts will be to test the temperature stability of all currently used foaming agents. Next, we shall concentrate on evaluating lab methods used for testing foaming agents. As you can see, the information you supply us is most important.

Being this project is government sponsored, all data gathered will be available to industry when the project is finished. If your "foaming agent" is chosen to be tested, I shall gladly give you early results.

If you have any questions, or if you wish to provide the information over the phone, please feel free to call.

sincerely,

Martin Chenevert

Pzesident

$\operatorname{MEC} / 1 \mathrm{P}$

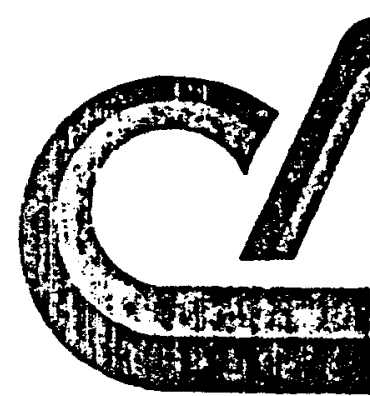

CHENEVERT \&

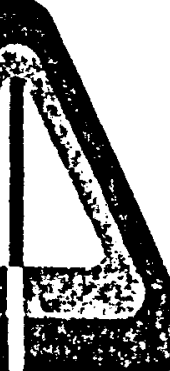

ASSOCIATES, INC. 2727 KIRBY DR., SUITE $201 /$ HOUSTON, TEXAS $77098 / 713522.2122$

Drilling Specia' sts 'Petroleum Consulting. Research. and Training 


\section{QUESTIONAIRE ON FOAM DRILLING FLUIDS \\ For Study Funded By: \\ Department of Energy \\ Division of Geothermal Energy}

Foans have been used by our company under the following conditions.

1. Maximum static temperature

2. Maximum depth

3. Problems often encountered

4. Type of foaming agent used (if known)

Supplied by (company).

5. I would like to see the following improvements made in foam.

6. Comments

7. Please place me on your "foar" mailing list. Yes $\square$ No $\square$ Name

Company

Street

City, state

Phone

Note: If more than one drilling location is involved please use additional sheets. 
QUESTIONAIRE

APPLICABILITY OF FOAM DRILLING FLUIDS

1. How much of geothermal drilling could utilize foam (by area and by resource type; if possible)?

2. What are the benefits of new foams over present drilling fluid systems (e.g. reduce drill pipe replacement, save drilling time, increase well productivity, etc.)?

3. What special problems limit utilization of foams (e.g. corrosion, disposal, equipment cost, and availability)?

4. What are the priorities for research on foams?

5. What are the chances of developing better foams ( 5 above) and how long will it take?

6. Are the needs for completion, fracturing, and workover foams significantly different from those of drilling foams?

7. Other comments. 


\section{GEOTHERMAL PERSONNEL CONTACTED ON \\ FOAM DRILLING FLUID STUDY}

R. B. All red

Sun 0 il Company

503 N. Central Expressway

Richardson, TX 75080

(214) 744-4411

G. W. Anderson

Chevron, U.S.A. Inc.

P. 0. Box 5355

0ildale, CA 93308

(805) $393-1312$

C. W. Berg

Phillips Petroleum Co.

P. 0. Box 752

Del Mar, CA 92014

(714) 755-0131

Gene C. Broaddus

Drilling fluids Section

Halliburton Services

Chemical Research Development Dept. Duncan, OK 73533

(405) $251-3427$

H. E. Bush

NL Baroid

6922 Triola

Houston, TX 77074

(713) $774-5205$

LeRoy Carney.

IMCO Services

2400 W. Loop South

P. O. BOX BOX 22605

Houston, TX 77027

(713) $67:-4881$

Ray Chantler

McCullough Geothermal Corp.

10880 Wilshire Blvd.

Los Angeles, CA 90024

(213) 879-5252
R. K. Clark

Shell Development Co.

P. 0. Box 481

Houston, TX

(713) $663-2421$

E. E. Clear

Drilling Specialties Co.

309 Short Street

Bartlesville, OK 74004

(918) 661-6404

R. A. (Bob) Crewdson

Occidential Geothermal, Inc.

5000 Stockdale Hwy.

Bakersfield, CA 93309

(805) $327-7351$

Bill Dolan

AMAX Exploration, Inc.

4704 Harlan Street

Denver, CO 80212

(303) 433-6151

David Etter

Schwebel Petroleum Co. 900 Sacramento Street

P. 0. Box 512

Bakersfield, CA 93203

(805) 324-4061

Paul Fisher

Union 011 Co. of California Research Department

P. 0. Box 76

Brea, CA 92621

(714) 528-7.201

William A. Glass

Big Chief Drilling Co.

P. 0. Box 14837

Oklahoma City, OK 73114 
Bob Greider

Intercontinental Energy Corp.

P. D. Box 17529

Denver, CO 80217

(303) $772-6703$

Tony Havlich Associates

5540 Pine Cone Road

Lacrescenta, CA 91214

(213) 249-0910

Tom Hinrichs

Magma Power Company

P. 0. BOX 2082

Escondido, CA 92025

(714) 743-7008

Stan Hutchinson

Chevron U.S.A. Inc.

P. O. Box 5355

Bakersfield, CA

(805) 393-1312

Robert M. Jorda

Completion Technology Co. 4200 Westheimer Suite 211 Houston, TX 77027

(713) 961-5011

John Kelly

Mobil Research

P. 0. Box 900

Dallas, TX 75221

Jim Kingsolver

Smith Tool Company

17871 Von-Karman Ave.

P. O. Box C-19511

Irvine, CA 92713

(714) 540-7010

Steve McVeigh

Shell oil Co.

$1200 \mathrm{Milan} \mathrm{St}$., Room 1828

Houston, TX 77001

(713) $241-1453$
Harvey Mallory

Loffland Brothers

Box 2847

Tulsa, OK 74101

Bob Mottley

Getty Oil Co.

P. 0. Box 1404

Houston, TX 77001

Robert W. Nicholson

Republic Geothermal, Inc.

$11823 \mathrm{E}$. Slauson

Santa Fe Springs, CA

(213) 945-3661

Charles Perricone

Milchem, Inc.

P. 0. Box 22111

Houston, TX 77027

(713) $965-8312$

Gene Polk

Baroid

6400 Uptown Blvd. 365-W

Albuquerque, NM 87110

(505) 883-5i55

Del Pyle

Union Oil Company

P. 0. Box 7600

Los Angeles, CA 90051

(213) 486-6262

Larry Roberts

Atlantic Richfield, Co.

P. 0. Box 2819

Dallas, TX 75221

(214) 651-4594

Jake Rudisill

Thermal Power Co.

601 California St.

San Francisco, CA 94108 
John J. Schneider

Shell oil Company

Entex Building

P. 0. Box 831

Houston, TX77001

(713) 241-2003

Bill Shaub

Gulf oil Company

P. 0. Box 36505

Houston, TX 77036

(713) 778-5161

Frank J. Shell

Division Manager

Phillips Petroleum

309 Short Street

Bartlesville, OK 74004

Robert A. Shore

Getty Oil Co. REI

P. 0. Box $197 X$

Bakersfield, CA 93306

(805) 399-2961

Dwight K. Smith

Halliburton

Technical Center

(405) 251-3494

Henry R. Straw

Texaco, Inc.

P. 0. Box 2100

Denver, C0.80201

(303) 861-4420

Roy Wolke

Dresser Industries

P. 0. Box 6504

Houston, TX 77005

(713) $78 !-8525$ 


\section{REPORT ON INFORMATION OBTAINED FROM}

GEOTHERMAL PERSONNEL

The concept suggested by Kingsolver that future DOE Projects look at the entire spectrum of inert gas and aireated fluids is a good one. This would essentially $f_{\perp l l}$ in the density range from air to water.

Areas in which foam research should be carried out are 11sted below. This list is obtained from failures encountered with existing foams. Not in order of priority.

1. Stability of foarns under water or brine intrusion.

2. Stabillty of foams under changing pressure (5000 feet depth maximum) and temperature $\left(550^{\circ} \mathrm{F}\right.$ max.) conditions.

3. Heat transfer/insulation properties of foams.

4. Heat capacity of foams.

5. Corrosion effects of foams, to include performance of additives.

6. Foam generators.

7. Foam disposal schemes.

8. Flow characteristics of foams in porous media and evaluation of rock alteration when in contact with foams.

9. Development of improved foamers, in particular, binary systems ala Fowkes.

10. Lifting capability of foams.

11. Sensitivity of foams to inert or stack gas with hydrocarbon impurities.

12. Improved performance parameters for physical and chemical properties of foams.

Most personnel contacted considered foams to be experimental and wanted to see lab tests and field tests performed to give themselves greater confidence in applying foams to their operations. Some proprietary R. \& D. Is going on but all would welcome DOE participation. No clear cut answer on percentage of drilling to be foam. This would be very closely tied to foam performance. 
The concept of binary foams was interesting and novel to most, however, the corrosion problem seemed to be of greater concern at the present time. The use of Inert gas to generate foam was the most popular present concept. 
Geothermal Survey

Date Iuly $5, \quad 1278$

rerson contacted

Stan Hutchison

Address Chevron U.S.A., Inc. P. O. Box 5355

Bakersfield, CA.

Phone Number $805-393-1312$

Objective: Determination of the degree of applicability of drilling foams for geothermal wells and the enviromental conditions of the borehole.

Topics to be covered:

1. In the future, where will foam drilling fluids be used?

2. How will foams cut costs?

3. What are the borehole conditions for foam drilling?

4. Will foam disposal be a problem?

5. Other considerations.

$\because x$. Hutchinson had the following comments:

I feel there will be many uses for foams in the future. They $\therefore$ ill be needed in the following areas.

A) For drilling in areas which need low density fluids. This is particularly true in geothermal areas. At present we are having problems with shale stability when foams are used. Work should look at additives for shale stability.

B) For completions. Stable foams are very useful for removing sand and scale from wells.

c) Use as a pusher fluid in secondary recovery operations. In recent lab tests cores were flooded at $3000 \mathrm{~F}$ using water only and only 30 of the oil in place was recovered. The next water flood was followed by stiff foam and a total of 43-488 oil was recovered.

D) Used in acidizing operations. After the primary acid job, foam is pumped into the holes formed. This plugs such holes and diverts the next acid job into less permeable zones. The bubbles which go into the formation lower the mobility of the acid. Also, the foam does not damage the zone and production is easily achieved.

E) Foams are used in more and more hydrofrac jobs. 
Date June 25,1978 Address $\mathrm{P}$. O. Box 2847

Person Contacted Mr. Harvey Mallory Tulsa, Oklahoma 74101

Phone Number $622-9330$

Objective: Determination of the degree of applicability of drilling foams for geothermal wells and the enviromental conditions of the borehole.

\section{Topics to be covered:}

1. In the future, where will foam drilling fluids be used?

2. How will foams cut costs?

3. What are the borehole conditions for foam drilling?

4. Will foam disposal be a problem?

5. Other considerations.

Mr. Mallery had the following comments:

1. Foams are presently difficult to use as drilling fluids, they are good mainly for completions.

2. The biggest problem with foam is keeping the foam continuous in the annulus. This is a foam degredation problem and injection problem. Often the driller and air man do not work together properly; you get a slug of foam then a slug of air. If you have the foam slugging you better not come out of the hole.

3. The main user of foam is Chevron. Contact them.

4. On one early well near $F t$. Stockton the chips fell back during connections, packed off the hole, then lost circulation when the pumps were turned on. 
Geothermal Survey

Date June 21,1978

Address Smith Tool Co.

Person Contacted Mr. Jim Kingsolver P. O. Box C-19511

Phone Number $714-540-7010$ Irvine, CA. 92713

Objective: Determination of the degree of applicability of drilling foams for geothermal wells and the enviromental conditions of the borehole.

Topics to be covered:

1. In the future, where will foam drilling fluids be used?

2. How will foams cut costs?

3. What are the borehole conditions for foam drilling?

4. Will foam disposal be a problem?

5. Other considerations.

Comments:

1. In the next 5 yrs, 75-808 of all geothermal wells drilled will have aerated water in one or more sections of the hole.

2. The reason for the aerated water system is to prevent lost circulation which therefore prevents problems and insures a producer.

3. Foam will be used, when possible, because of the lower cost.

4. Problems with todays foams are:

a. Low yield (ie, foam does not form)

b. The $\mathrm{pH}$ is wrong. You get either 3 or 13, nothing in between.

c. Bit life is very low. 
Date June 21,1978 Address Union Oil Co. P. O. Box 7600

Person Contacted Mr. Del Pyle Los Angeles, CA.

Phone Number 213-486-6262

Objective: Determination of the degree of applicability of drilling foams for geothermal wells and the enviromental conditions of the borehole.

Topics to be covered:

1. In the future, where will foam drilling fluids be used?

2. How will foams cut costs?

3. What are the borehole conditions for foam drilling?

4. Will foam disposal be a problem?

5. Other considerations.

Comments: The following points were made by Mr. Del Pyle and Mr. Bill Glass in a joint meeting.

Mr. Bill Glass Big Chief Drilling Co. 405-843-5721 Oklahoma City, OK.

1. With the exception of sedimentary type geothermal areas (ie Imperial Valley), foam fluids will be used in about 508 of all other geothermal wells. (See attached Table 1)

2. Foams look very good becuase of savings over air. They will be used where air is presently being used.

Other advantages of foam over air are:

a. Fewer compressors will be needed. Can reduce number from three to one. This will save between $\$ 1500$ to $\$ 2000 /$ day.

b. Pipe corrosion and erosion will be reduced. With air you need to retire one foot of drill pipe for every 6 feet of hole drilled. With foam you retire one foot of drill pipe for every 250 of hole drilled. At $\$ 20$ ' foot of drill pipe, considerable savings can be achier...:

c. Hard banding. We presently spend (in Geyser Area) about $\$ 10,000$ to $\$ 15,000$ per hole for hard banding wh:": air is used. Foam might cut this back to $\$ 8000$ to $\$ 12,000$ per hole. 
Page Two

Mr. Del Pyle

Juen 21, 1978

d. Fishing jobs with air is about 4 jobs/year/rig. At $\$ 250,000$ per job this amounts to $\$ 1,000,000 /$ year/rig. Foam might reduce this value by 10 times. Its main contribution would be in hole stability.

e. Pipe inspection costs. Drill collars would be checked every 30 days, instead of every 20 days. It presently costs $\$ 12 / j o i n t$ to inspect. 
Mr. Frank Schuh

Atlantic Richfield Co.

Dallas, Texas

(214)651-4685

Sumary:

Company has not drilled geothermal wells to date. They are Interested and have leases. Suggest we review the University of Hawail report on dry steam geothermal wells in Hawa11.

Major concern on the use of foams is abllity of foam to handle water zones.

Mr. Bob Mottley

Getty Oil Co.

Houston, Texas

(713) 658-9361

Sumbary :

No experience and no knowledge on the use of foams in geothermal drilling.

Mr. Dave Smith

Shell Oil Co.

Ventura, California

(805) 648-2751

Surmary :

All experience at Geysers. Not wuch application of foams to this location. Foars are used to clear water influx, however, at Geysers the geothermally altered rock at depth is unstable and foams could not clear the hole fast enough. 
Mr. B. Hyant

Occidental Geothermal, Inc.

Bakersfield, Calif ornia

(805) 327-7351

Surmary:

He had no direct experience with the use of foams. He considered the use of foams to be very experimental, would like to see $R$. \& D. on foams, particularly interested in the stability of foams at depth.

His supervisor is Mr. R. A. Crewdson; Crewdson will send us the completed questionaire.

Mr. Percy Wicklund

Alax Exploration, Inc.

Denver, Colorado

(303) 433-6151

Sumary:

AMAX has used foams and believes that they have a place in geothermal drilling. Because of the hazard of blind drilling, no circulation back to the surface, he feels that the drilling manager must be very conservative in the use of foams. In addition a breakdown of the foam structure can lead to water surging in the borehole under high pressure resulting in damage to the borehole.. Evaluation of the sensitivity of the foam to geothermal brines is an important $R$. \& $D$. parameter.

Since geothermal drilling is in hard rock he would like to see government geothermal test wells use foams to prove their utility.

Mr. R. M. Jorda

Completion Technology Co.

Houston, Texas

(T13) $961-5011$

Summary:

This company has not used foams in the geothermal environment. They have used foams as a completion material. In this usage they have better completions with foam primarily because foams do not affect the reservoir. He is mostly interested in stiff foams, defined as one which can carry propping agents.

For future $R$. \& $D$. he considers development of high temperature foamers as \#1. He likes the idea of binary systems of low 
temperature/high temperature foaring agents. The disposal of stiff foams is a problem and reducing cost of equipment to do this job is Important.

Mr. Stan Shrylock

Halliburton

Santa Fe Springs, Cal1fornia

(213) $864-2551$

Sumary:

Air drilling at the Geysers is most satisfactory. In the Imperial Valley foams are $0 . K$. Major problem with foams is lost clrculation.

Suggest we review new patented process of foam utilization by Chevron Oil, U.S.A. Details of this process were presented at the API Meeting in California two weeks ago.

Mr. R. B. Allred

Sun Oil Co.

Richardson, Texas

(214) 744-4411

Sunurary:

Unable to contact him.

Mr. R. Lane

NL Baroid

Houston, Texas

(713) $527-1302$

Surnary:

Baroid's experlence with foams is mainly lab development work oriented toward water and gas well drilling. Mostly this work is at low temperatures. They have studied the effect of water/ brine chemicals on foaming agents. Their usual percentage of surfactant is $2 \%$ which Implies a wet foam.

Basically alr drilling is fastest, but uses foams to control water encroachment and for better lifting capability. Also equipment cost is reduced over mud drilling, provided of course that air drilling equipment is in place. 
They use the API RP4G test for foams and would like to see improved test procedures.

Would welcome Govt. R. \& D. In this area.

Mr. David Etter

Schwebel Petroleum Co.

Bakersfield, California

(805) 324-4061

Surmary:

No contact. No one else at company could provide information.

Mr. W. A. Glass

Bis Chief Drilling Co.

Ok lahoma City, Oklahoma

(405) 843-5721

Summary:

No new comments.

Mr. L. Carney

IMCO Services

Houston, Texas

(713) 671-4882

Summary:

I was unable to contact Mr. Carney or any other engineer at IMCO.

I was referred to Mr. Stewart of Technical Sales.

Mr. E. E. Clear

Drilling Speclalities Co.

Bartlesville, Oklahoma

(918) 661-6404

Summary:

Mr. Clear reported no knowledge or familiarity with the use of foams. 
Mr. P. Fisher

Union 0il Co. of Callfornia

Brea, California

(714) 528-7201

Summary :

I was unable to contact him.

Mr. Tony Havlich

Havlich Associates

LaCresenta, California

(213) 249-0910

Summary :

Mr. Havlich stated that most foam drilling activities were at a depth of 1000 feet with 5000 feet being the maximum. He was interested in the PVT properties of foams and would like to know more about the effects of additives such as corrosion inhibitors (Unisteam produced by Union $011 \mathrm{Co}_{.}$) and buffers. Unisteam is a vapor phase material which setrles out on steel surfaces at elevated temperatures. He suggested Texilana and Far Best Corp. as suppliers of organic sulfate chemicals. Considered film strength, flow properties in porous medla and thermal insulation properties of foams as important tests. Standard 011 of Bakerfield, California has been testing foams also the IMCO Corp. is involved in foaw testing. Mr. Havlich was interested in generating foams with inert gas and mentioned the NOWSCO Co. (Nitrogen 011 Well Service Co.) of Houston, Texas.

Of most use to industry would be a practical well drill test run by knowledgeable people. Suggests we look at the remedial test run at the LaHabra facility.

Mr. S. Hutchison

Chevron U.S.A., Inc.

Bakerfield, California

(805) $393-1312$

Summary:

No contact. 
H.T. E1ll Schaub

rulf Oil Co.

houston, Texas

(7.13) $778-5163$

Surmary:

No contact.

Mr. K. Kingsolver

Sinth Tool Co.

Irvine, California

(714) $540-7010$

Sumary :

Considers corrosion the 11 problem with foams. Suggests using inert gas in particular stack gas. The company Ken Davis Ind. may be doing some work on this.

Presently the only stable foam is the one used by Chevron for completions and 1 it is a low temperature foam. The lost circulation problem with unstable foams is very serious. He believes well tests to be useful and lab tests are a must. $75 \%$ of wells will be completed with foams or mist techniques and suggests that scope of future DOE programs be expanded to cover all inert gas and aireated fluids.

Mr. Del Pyle

Union Oil Co.

Los Angeles, California

(213) 486-6262

Sumary:

No new comments. 
Mr. R. Wolke

Dresser Industries

Houston, Texas

(713) $784-8525$

Sumary:

Likes inert gas to reduce corrosion but major problems exist with stack gas. Keeping the stack gas clean and reducing hydrocarbon content is difficult and expensive. Presently available catalytic converters are not cost effective.

He cites other problens with foams as lost circulation, disposal, and design of foar generators. 
Distribution:

TID-4500-R66 UC-66C (752)

400 C. Winter

1000

G. A. Fowler

1100

C. D. Broyles

1130 H. E. Viney

2000 E. D. Reed

2300 J. C. King

$2320 \mathrm{~K}$. Gillespie

2325 R. E. Fox

2328 J. H. Barnette

2500 J. C. Crawford

2513 W. B. Leslie

4000 A. Narath

4200 G. Yonas

4300 R. I. Peurifoy, Jr.

4400 A. W. Snyder

4443 P. Yarrington

4500 J. H. Scott

4710 G. E. Brandvold

4720 V. L. Dugan

4730 H. M. Stoller

4740 R. K. Traeger

4741 S. G. Varnado

4742 A. F. Veneruso

4743 H. C. Hardee

4744 H. M. Dodd

4744 C. C. Carson

4745 J. R. Tillerson

5000 J. K. Galt

5510 D. B. Hayes

5512 D. F. McVey

5512 A. Ortega

5530 W. Herrmann

5532 B. M. Butcher

5533 J. M. McGlaun

5600 D. B. Schuster

5620 M. M. Newsom

5800 R. S. Claassen

5810 R. G. Kepler

5812 C. J. M. Northrup, Jr.

5812 B. T. Kenna

5813 P. B. Rand

5830 M. J. Davis

5831 N. J. Magnani

5832 R. W. Rohde

5832 R. J. Salzbrenner

5833 J. L. Ledman

5833 J. L. Jellison

3141 T. L. Werner (5)

3151 W. L. Garner (3)

8266 E. A. Aas 